\title{
Long-term effects of weight-reducing diets in people with hypertension (Review)
}

Semlitsch T, Jeitler K, Berghold A, Horvath K, Posch N, Poggenburg S, Siebenhofer A

Semlitsch T, Jeitler K, Berghold A, Horvath K, Posch N, Poggenburg S, Siebenhofer A.

Long-term effects of weight-reducing diets in people with hypertension.

Cochrane Database of Systematic Reviews 2016, Issue 3. Art. No.: CD008274.

DOI: 10.1002/14651858.CD008274.pub3.

www.cochranelibrary.com 
TABLE OF CONTENTS

HEADER 1

ABSTRACT

PLAIN LANGUAGE SUMMARY

SUMMARY OF FINDINGS

BACKGROUND

OBJECTIVES

METHODS

RESULTS

Figure 1.

Figure 2.

Figure 3.

Figure 4.

Figure 5.

Figure 6.

DISCUSSION

AUTHORS' CONCLUSIONS

ACKNOWLEDGEMENTS

REFERENCES

CHARACTERISTICS OF STUDIES

DATA AND ANALYSES

Analysis 1.1. Comparison 1 Weight-reducing diet versus no weight-reducing diet, Outcome 1 Change in systolic blood pressure from baseline to endpoint.

Analysis 1.2. Comparison 1 Weight-reducing diet versus no weight-reducing diet, Outcome 2 Change in diastolic blood pressure from baseline to endpoint.

Analysis 1.3. Comparison 1 Weight-reducing diet versus no weight-reducing diet, Outcome 3 Change in body weight from baseline to endpoint.

ADDITIONAL TABLES

APPENDICES

WHAT'S NEW

CONTRIBUTIONS OF AUTHORS

DECLARATIONS OF INTEREST

SOURCES OF SUPPORT

DIFFERENCES BETWEEN PROTOCOL AND REVIEW

INDEX TERMS 
[Intervention Review]

\section{Long-term effects of weight-reducing diets in people with hypertension}

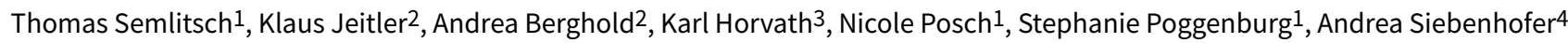

1Institute of General Practice and Evidence-Based Health Services Research, Medical University of Graz, Graz, Austria. 2 Institute of General Practice and Evidence-Based Health Services Research / Institute of Medical Informatics, Statistics and Documentation, Medical University of Graz, Graz, Austria. Institute of General Practice and Evidence-Based Health Services Research / Department of Internal Medicine, Division of Endocrinology and Metabolism, Medical University of Graz, Graz, Austria. ${ }^{4}$ Institute of General Practice and Evidence-Based Health Services Research, Medical University of Graz, Graz, Austria / Institute of General Practice, Goethe University, Frankfurt am Main, Germany

Contact address: Thomas Semlitsch, Institute of General Practice and Evidence-Based Health Services Research, Medical University of Graz, Auenbruggerplatz 2/9, Graz, 8036, Austria. thomas.semlitsch@medunigraz.at.

Editorial group: Cochrane Hypertension Group.

Publication status and date: New search for studies and content updated (no change to conclusions), published in Issue 3, 2016.

Citation: Semlitsch T, Jeitler K, Berghold A, Horvath K, Posch N, Poggenburg S, Siebenhofer A. Long-term effects of weightreducing diets in people with hypertension. Cochrane Database of Systematic Reviews 2016, Issue 3. Art. No.: CD008274. DOI: 10.1002/14651858.CD008274.pub3.

Copyright $@ 2016$ The Cochrane Collaboration. Published by John Wiley \& Sons, Ltd.

\section{A B S T R A C T}

\section{Background}

All major guidelines for antihypertensive therapy recommend weight loss. Thus dietary interventions that aim to reduce body weight might be a useful intervention to reduce blood pressure and adverse cardiovascular events associated with hypertension.

\section{Objectives}

\section{Primary objectives}

To assess the long-term effects of weight-reducing diets in people with hypertension on all-cause mortality, cardiovascular morbidity, and adverse events (including total serious adverse events, withdrawal due to adverse events, and total non-serious adverse events).

\section{Secondary objectives}

To assess the long-term effects of weight-reducing diets in people with hypertension on change from baseline in systolic blood pressure, change from baseline in diastolic blood pressure, and body weight reduction.

\section{Search methods}

We obtained studies from computerised searches of the Cochrane Central Register of Controlled Trials (CENTRAL), the Cochrane Hypertension Specialised Register, Ovid MEDLINE, and Ovid EMBASE, and from searches in reference lists, systematic reviews, and the clinical trials registry ClinicalTrials.gov (status as of 2 February 2015).

\section{Selection criteria}

We included randomised controlled trials (RCTs) of at least 24 weeks' duration that compared weight-reducing dietary interventions to no dietary intervention in adults with primary hypertension.

\section{Data collection and analysis}

Two review authors independently assessed risk of bias and extracted data. We pooled studies using fixed-effect meta-analysis. In case of moderate or larger heterogeneity as measured by Higgins $\mathrm{I}^{2}$, we used a random-effects model. 


\section{Main results}

This review update did not reveal any new studies, so the number of included studies remained the same: 8 studies involving a total of 2100 participants with high blood pressure and a mean age of 45 to 66 years. Mean treatment duration was 6 to 36 months. We judged the risk of bias as unclear or high for all but two trials. No study included mortality as a predefined outcome. One RCT evaluated the effects of dietary weight loss on a combined endpoint consisting of the necessity of reinstating antihypertensive therapy and severe cardiovascular complications. In this RCT, weight-reducing diet lowered the endpoint compared to no diet: hazard ratio 0.70 ( $95 \%$ confidence interval $(\mathrm{Cl}), 0.57$ to 0.87$)$. None of the studies evaluated adverse events as designated in our protocol. There was low-quality evidence for a blood pressure reduction in participants assigned to weight loss diets as compared to controls: systolic blood pressure: mean difference (MD) -4.5 $\mathrm{mm} \mathrm{Hg}(95 \% \mathrm{Cl}-7.2$ to $-1.8 \mathrm{~mm} \mathrm{Hg}$ ) (3 of 8 studies included in analysis), and diastolic blood pressure: $\mathrm{MD}-3.2 \mathrm{~mm} \mathrm{Hg}(95 \% \mathrm{Cl}-4.8$ to -1.5 $\mathrm{mm} \mathrm{Hg}$ ) (3 of 8 studies included in analysis). There was moderate-quality evidence for weight reduction in dietary weight loss groups as compared to controls: MD $-4.0 \mathrm{~kg}(95 \% \mathrm{Cl}-4.8$ to -3.2$)$ ( 5 of 8 studies included in analysis). Two studies used withdrawal of antihypertensive medication as their primary outcome. Even though we did not consider this a relevant outcome for our review, the results of these studies strengthen the finding of reduction of blood pressure by dietary weight loss interventions.

\section{Authors' conclusions}

In this update, the conclusions remain the same, as we found no new trials. In people with primary hypertension, weight loss diets reduced body weight and blood pressure, however the magnitude of the effects are uncertain due to the small number of participants and studies included in the analyses. Whether weight loss reduces mortality and morbidity is unknown. No useful information on adverse effects was reported in the relevant trials.

\section{PLAIN LANGUAGE SUMMARY}

\section{Weight-reducing diets for people with elevated blood pressure}

Compared to the general population, people with high blood pressure have a higher risk of death and complications such as heart attack or stroke. Dietary interventions to lower body weight are commonly recommended as a first therapeutic step for overweight people with high blood pressure, based on the association of increased weight and increased blood pressure. However, whether weight loss has a longterm effect on blood pressure and reduces the adverse effects of elevated blood pressure remains unclear.

As only randomised controlled trials (RCTs) comparing groups with and without a weight-reducing diet can answer these issues, we only included RCTs in our systematic review. Thirty articles reporting on eight studies met the inclusion criteria. The 8 included studies involved a total of 2100 participants with high blood pressure and a mean age of 45 to 66 years. Mean treatment duration was 6 to 36 months, and there was little or no information about deaths or other long-term complications. Three of eight studies provided effects on systolic and diastolic blood pressure, suggesting that weight loss interventions reduced systolic and diastolic blood pressure by $4.5 \mathrm{~mm} \mathrm{Hg}$ and 3.2 $\mathrm{mm} \mathrm{Hg}$, respectively. Five out of eight studies reported body weight; weight loss interventions reduced weight by $4.0 \mathrm{~kg}$ as compared to controls. No useful information on adverse effects was reported in the included trials.

In conclusion, we found no evidence for effects of weight loss diets on death or long-term complications and adverse events. Results on blood pressure and body weight should be considered uncertain, because not all studies were included in the analyses. 


\section{SUMMARY OF FINDINGS}

\section{Summary of findings for the main comparison.}

Weight-reducing diets compared to no weight-reducing diets for adults with essential hypertension

Patient or population: Men and non-pregnant women $\geq 18$ years old with essential hypertension

Intervention: Weight-reducing diets

Comparison: No weight-reducing diets

\begin{tabular}{|c|c|c|c|c|}
\hline Outcomes & $\begin{array}{l}\text { Effect estimate } \\
(95 \% \mathrm{Cl})\end{array}$ & $\begin{array}{l}\text { No of Partic- } \\
\text { ipants } \\
\text { (studies) }\end{array}$ & $\begin{array}{l}\text { Quality of } \\
\text { the evi- } \\
\text { dence } \\
\text { (GRADE) }\end{array}$ & $\begin{array}{l}\text { Com- } \\
\text { ments }\end{array}$ \\
\hline $\begin{array}{l}\text { Changes in systolic blood pressure } \\
{[\mathrm{mm} \mathrm{Hg}] \text { from baseline to end of study }}\end{array}$ & $\begin{array}{l}\text { MD }-4.49 \\
(-7.20 \text { to }-1.78)\end{array}$ & $\begin{array}{l}731 \\
\text { (3 studies) }\end{array}$ & $\begin{array}{l}\oplus \oplus \ominus \ominus \\
\text { low1,2 }\end{array}$ & \\
\hline $\begin{array}{l}\text { Changes in diastolic blood pressure } \\
{[\mathrm{mm} \mathrm{Hg}] \text { from baseline to end of study }}\end{array}$ & $\begin{array}{l}\text { MD }-3.19 \\
(-4.83 \text { to }-1.54)\end{array}$ & $\begin{array}{l}731 \\
\text { (3 studies) }\end{array}$ & $\begin{array}{l}\oplus \oplus \ominus \ominus \\
\text { low1,2 }\end{array}$ & \\
\hline $\begin{array}{l}\text { Changes in body weight } \\
{[\mathrm{kg}] \text { from baseline to end of study }}\end{array}$ & $\begin{array}{l}\text { MD }-3.98 \\
(-4.79 \text { to }-3.17)\end{array}$ & $\begin{array}{l}880 \\
\text { (5 studies) }\end{array}$ & $\begin{array}{l}\oplus \oplus \oplus \ominus \\
\text { moderate }^{\mathbf{1}}\end{array}$ & \\
\hline $\begin{array}{l}\text { Cardiovascular morbidity } \\
\text { combined endpoint: necessity of reinstating antihypertensive } \\
\text { therapy and severe cardiovascular complications } \\
\text { Follow-up: } 30 \text { months }\end{array}$ & $\begin{array}{l}\text { HR } 0.70 \\
(0.57 \text { to } 0.87)\end{array}$ & $\begin{array}{l}294 \\
\text { (1 study) }\end{array}$ & $\begin{array}{l}\oplus \odot \Theta \odot \\
\text { very } \\
\text { low } \mathbf{1 , 2 , 3}\end{array}$ & $\begin{array}{l}\text { Combined } \\
\text { outcome } \\
\text { includes } \\
\text { events } \\
\text { of much } \\
\text { different } \\
\text { severity }\end{array}$ \\
\hline
\end{tabular}

CI: confidence interval; HR: hazard ratio; MD: mean difference

GRADE Working Group grades of evidence

High quality: Further research is very unlikely to change our confidence in the estimate of effect.

Moderate quality: Further research is likely to have an important impact on our confidence in the estimate of effect and may change the estimate.

Low quality: Further research is very likely to have an important impact on our confidence in the estimate of effect and is likely to change the estimate.

Very low quality: We are very uncertain about the estimate.

1 High risk of bias in available randomised controlled trials.

2Wide confidence intervals.

3Only 1 randomised controlled trial. 


\section{B A C K G R O U N D}

\section{Description of the condition}

Hypertension is a chronic condition associated with an increased risk of cardiovascular mortality and morbidity. It is estimated that high blood pressure leads to over 9 million deaths each year (WHO 2013). Lowering blood pressure levels in people with hypertension has been shown to be an effective means of reducing cardiovascular morbidity and mortality (Staessen 2005; Turnbull 2003).

Epidemiological investigations have consistently found an association between high blood pressure and different lifestyle factors, excess body weight among them (Kenchaiah 2002; Wannamethee 1996; Wilson 2002; Woodward 2005; Yusuf 2004). Some recently published systematic reviews of randomised controlled trials (RCTs) also supported this assumption, showing that weight loss intervention resulted in lower blood pressure (Aucott 2005; Dickinson 2006; Horvath 2008). High body weight is also associated with increased cardiovascular complications (Kenchaiah 2002; Wilson 2002). However, the observation that certain variables (for example excess body weight, high blood pressure) are quantitatively related to more cardiovascular events does not necessarily mean that lowering these variables will automatically reduce the number of cardiovascular events. This may be due to the fact that the variable in question (for example overweight) has no impact on aetiological pathways or that the damage to the cardiovascular system is already established and is only poorly or no longer reversible. It could also be the case that the treatment is effective and does lower cardiovascular events by reducing the risk factor, but at the same time increases cardiovascular or other risks through a different mechanism. To prove the effectiveness of an intervention, an RCT is required, for which, ideally, a protocol was published prospectively. Numerous interventions that have been recommended on the basis of associations found in epidemiological studies eventually failed to show any beneficial effect, and sometimes even did harm in subsequent RCTs, for example a large dietary-intervention study of 8.1 years duration in 48,835 obese postmenopausal women (40\% having hypertension) resulted in only a modest reduction in diastolic blood pressure and no significant reduction of any cardiovascular outcomes (Howard 2006).

Nevertheless, weight reduction is recommended in major guidelines as a first-step intervention in the therapy of people with hypertension (CHEP 2014; ESH-ESC 2013; JNC 2014; NICE 2011; WHO 2005). Body weight may be reduced by non-pharmacological, pharmacological, or invasive interventions. A recently published Cochrane review of pharmacological interventions for weight reduction showed that orlistat reduced blood pressure and sibutramine increased blood pressure (Siebenhofer 2013). As of 2013, there were no RCTs testing the effect of invasive interventions in people with elevated blood pressure (Wilhelm 2014).

The aim of this systematic review was to evaluate the potential beneficial and harmful long-term effects for people with hypertension who intend to reduce their body weight with nonpharmacological dietary interventions.

\section{Description of the intervention}

This review covers dietary interventions (duration of at least 24 weeks) that aim to reduce body weight (for example dietary counselling, caloric restrictions, reduction in fat intake). We did not include other interventions such as exercise or other non-drug approaches such as stress reduction techniques.

\section{How the intervention might work}

Observational studies of non-pharmacological dietary measures in people with hypertension have suggested a positive association between body weight and blood pressure. One might therefore hypothesise that dietary intervention with the aim of reducing body weight would reduce blood pressure and adverse cardiovascular events in people with hypertension.

\section{Why it is important to do this review}

For overweight people with established hypertension, it is commonly recommended that blood pressure should first be managed by non-pharmacological interventions, including weight reduction (CHEP 2014; ESH-ESC 2013; JNC 2014; NICE 2011; WHO 2005). Since dietary interventions might support the efforts of patients to reduce body weight, it is important for the physician to be informed about the efficacy and potential harms of diets before recommending them.

Other reviews and meta-analyses have shown that nonpharmacological weight-reducing interventions lead to reduction in blood pressure (Horvath 2008; IQWiG 2006). None of these reviews provided data to establish whether long-term weight loss dietary interventions can lower the risk of mortality or cardiovascular morbidity.

This systematic review is an update of the previously published Cochrane review Siebenhofer 2011.

\section{O B JECTIVES}

\section{Primary objectives}

To assess the long-term effects of weight-reducing diets in people with hypertension on all-cause mortality, cardiovascular morbidity, and adverse events (including total serious adverse events, withdrawal due to adverse events, and total non-serious adverse events).

\section{Secondary objectives}

To assess the long-term effects of weight-reducing diets in people with hypertension on change from baseline in systolic blood pressure, change from baseline in diastolic blood pressure, and body weight reduction.

\section{METHODS}

\section{Criteria for considering studies for this review}

\section{Types of studies}

We included RCTs of at least 24 weeks' duration that compared weight-reducing dietary interventions to no dietary intervention in adults with primary hypertension. Any additional pharmacological or non-pharmacological co-intervention must have been administered to all randomised participants and must 
not have been significantly different for the treatment and control groups at baseline or during the duration of the trial.

For example, we did not include a randomised trial with exercise plus diet versus no treatment. A trial in which all randomised participants exercised, and the only difference was weight-reducing diet versus no treatment or placebo would have met the inclusion criteria.

\section{Types of participants}

We included men and non-pregnant women 18 years of age or older with essential hypertension (defined as baseline systolic blood pressure of at least $140 \mathrm{~mm} \mathrm{Hg}$ and/or baseline diastolic blood pressure of at least $90 \mathrm{~mm} \mathrm{Hg}$ or people on antihypertensive treatment).

\section{Types of interventions}

Dietary intervention with the intention to reduce body weight in comparison with no dietary intervention to reduce body weight.

\section{Types of outcome measures}

\section{Primary outcomes}

1. total mortality

2. cardiovascular morbidity

3. adverse events (including total serious adverse events, withdrawal due to adverse events, and total non-serious adverse events)

\section{Secondary outcomes}

1. change from baseline in systolic blood pressure

2. change from baseline in diastolic blood pressure

3. change in body weight

\section{Search methods for identification of studies}

\section{Electronic searches}

We searched the Database of Abstracts of Reviews of Effectiveness (DARE) for related reviews up to March 2015.

We searched the Cochrane Central Register of Controlled Trials (CENTRAL), the Database of Abstracts of Reviews of Effects (DARE) (up to March 2015), the Cochrane Database of Systematic Reviews (up to March 2015), Ovid MEDLINE (1966 to February 2015), and Ovid EMBASE (1988 to February 2015) to identify relevant randomised controlled trials.

We searched the following databases for primary studies: the Cochrane Hypertension Specialised Register (all years to February 2015), CENTRAL via the Cochrane Register of Studies Online (2015, Issue 2), Ovid MEDLINE (1946 to February 2015), Ovid EMBASE (1980 to February 2015) and ClinicalTrials.gov (all years to February 2015).

We translated the MEDLINE search strategy into the Cochrane Hypertension Specialised Register, CENTRAL, and EMBASE, using the appropriate controlled vocabulary as applicable (Appendix 1). The search strategy used in the original review is documented in Appendix 2. The Cochrane Hypertension Specialised Register includes searches of the WHO International Clinical Trials Registry Platform.

\section{Searching other resources}

1. Reference lists of all papers and relevant reviews identified.

2. Authors of relevant papers were contacted regarding any further published or unpublished work.

3. Authors of trials reporting incomplete information were contacted to provide the missing information.

4. Clinical trials registry: ClinicalTrials.gov.

\section{Data collection and analysis}

\section{Selection of studies}

Two review authors independently screened the title and abstract of each reference identified by the search and applied the inclusion criteria. Potentially relevant studies were retrieved in full and again two review authors independently decided, whether these studies met the inclusion criteria. In case of disagreement, we also obtained the full article and the two review authors inspected it independently. A third review author resolved disagreements. If a resolution of the disagreement was not possible, we added the article to those 'awaiting assessment' and contacted the authors of the study for clarification. We re-assessed the articles after receiving the authors' replies.

\section{Data extraction and management}

Two review authors independently extracted data from each included study using a standardised data extraction form. Differences in data extraction were resolved by consensus, referring back to the original article. If necessary, we sought information from the authors of the primary studies. We extracted, checked, and recorded the following data.

- General information including the sponsor of the trial (specified, known, or unknown) and country of publication.

- All characteristics of the trial, participants, interventions, and outcome measures were summarised as reported in the publication.

- Characteristics of the trial comprised the study design, duration of the trial, method of randomisation, allocation concealment, blinding (participants, people administering treatment, outcome assessors) and testing of blinding. We reported the characteristics of randomised participants at baseline and checked the similarity of groups at baseline.

- Characteristics of participants are summarised in the Characteristics of included studies table and comprise the number of participants in each group, how the participants were selected (random), exclusion criteria used, and general characteristics (e.g. age, gender, nationality, ethnicity).

- Relevant information regarding duration of the intervention, length of follow-up (in months), and types of dietary weightreducing interventions.

- Data of outcome measures concerning total mortality, cardiovascular morbidity (including stroke, myocardial infarction, sudden death, heart failure, etc.), total serious adverse events, withdrawals due to adverse events, total non-serious adverse events, mean change from baseline in systolic and diastolic blood pressure, as well as change in body weight. 


\section{Assessment of risk of bias in included studies}

Two review authors independently assessed trials meeting the inclusion criteria to evaluate methodological quality. Any differences in opinion were resolved by discussion with a third review author. We assessed all trials meeting the inclusion criteria using the 'Risk of bias' assessment tool under the categories adequate sequence generation, allocation concealment, blinding, incomplete outcome data, selective reporting, and other biases (Higgins 2011).

We carefully evaluated important numerical data such as screened, eligible, and randomised patients, as well as intention-to-treat (ITT) and per-protocol (PP) population. We investigated attrition rates, for example dropouts, losses to follow-up, and withdrawals. Issues of missing data, ITT, and PP were critically appraised and compared to specifications for primary outcome parameters and power calculation.

\section{Measures of treatment effect}

We used risk ratio with $95 \%$ confidence interval for dichotomous variables such as total mortality, cardiovascular morbidity, total withdrawals, and withdrawals due to adverse events. We calculated mean difference for the mean change in systolic as well as diastolic blood pressure and body weight between the groups. If the standard deviation of the mean change was not explicitly given in the study, it was calculated from confidence intervals and standard error of the mean or estimated from $P$ values.

The position of the patient during blood pressure measurement may affect the blood pressure-lowering effect. When measurements were reported for more than one position, the order of preference was: 1) sitting; 2) standing; and 3) supine (Musini 2009).

\section{Dealing with missing data}

If necessary, we contacted authors of trials reporting incomplete information to provide the missing information.

\section{Assessment of heterogeneity}

We assessed heterogeneity using Higgins $1^{2}$. In the case of substantial heterogeneity ( 12 greater than $50 \%$ ), we had planned to perform sensitivity and subgroup analyses for the following items: study quality, PP versus ITT analyses, sex, age, body mass index, concomitant diseases, ethnicity, blood pressure at baseline, blood pressure goals, concomitant antihypertensive therapy, and socioeconomic status.

\section{Assessment of reporting biases}

We tested publication bias and small-study effects in general using the funnel plot or other corrective analytical methods depending on the number of clinical trials included in the systematic review.

\section{Data synthesis}

We summarised data statistically if they were available, sufficiently similar, and of adequate quality. We performed data synthesis and analyses using the Cochrane Review Manager software, Review Manager 5. We performed statistical analysis according to the statistical guidelines referenced in the Cochrane Handbook for Systematic Reviews of Interventions (Higgins 2011). We used fixedeffects model for the meta-analyses. In case of moderate or larger heterogeneity as measured by Higgins $1^{2}$, random-effects model was used and presented.

\section{Subgroup analysis and investigation of heterogeneity}

We performed subgroup analyses where appropriate. Heterogenity among participants could be related to, for example, sex, age, body mass index, concomitant diseases, ethnicity, blood pressure at baseline, blood pressure goals, concomitant antihypertensive therapy, and socioeconomic status.

\section{Sensitivity analysis}

We tested robustness of results where appropriate using several sensitivity analyses (for example study quality or PP versus ITT analyses, studies with large drop-out rates and losses to follow-up).

\section{RE S U L T S}

\section{Description of studies}

See: Characteristics of included studies; Characteristics of excluded studies

\section{Results of the search}

Our search of the electronic databases yielded 11,332 records, of which 3422 could be excluded as duplicates. Of the remaining 7910 publications, we excluded 7812 by consensus as not relevant to the question under study on the basis of their abstracts. In addition, we identified one study among the references of a report of the Institute for Quality and Efficiency in Health Care (IQWiG 2006), and found two further articles in the reference lists of included trials and relevant reviews, resulting in 101 articles for further examination. After screening the full texts of these publications, we found 31 articles on 8 studies that met the inclusion criteria (see Figure 1 for details of the PRISMA (Preferred Reporting Items for Systematic Reviews and Meta-Analyses) statement (PRISMA 2009)). 
Figure 1. Study flow diagram.

Potentially relevant articles

from electronic databases (MEDLINE, EMBASE, CENTRAL, Hypertension Group Specialised Register) $n=11332$

\section{Duplicates: $\mathbf{n}=\mathbf{3 4 2 2}$}

Titles or abstracts excluded because they did not fulfill inclusion criteria: $\mathbf{n}=\mathbf{7 8 1 2}$

Articles retrieved for more detailed evaluation:

$$
\mathrm{n}=\mathbf{9 8}
$$

\begin{tabular}{|l|l|}
\hline & $\begin{array}{l}\text { References derived from reference lists in } \\
\text { relevant RCTs and reviews: } \\
n=3\end{array}$ \\
& $\begin{array}{l}\text { Full text articles excluded: } n=68 \\
\text {-not an RCT ( } n=7) \\
\text {-no patients with essential hypertension }(n=8) \\
\text {-no information on hypertensive subgroup }(n=23) \\
\text {-intervention not a weight reducing diet }(n=5) \\
\text {-combination of different interventions }(n=10) \\
\text {-inappropriate control intervention }(n=2) \\
\text {-different accompanying therapy }(n=1) \\
\text {-intervention }<24 \text { weeks ( } n=7) \\
\text {-no full text available }(n=5)\end{array}$ \\
\hline & $\begin{array}{l}\text { Articles excluded after correspondence with the } \\
\text { investigators: } n=2 \\
\text {-insufficient data }(n=2)\end{array}$ \\
\hline
\end{tabular}

Articles that met inclusion criteria:

$$
\mathrm{n}=31 \text { (8 studies) }
$$




\section{Included studies}

We have provided details of the characteristics of the included studies in the Characteristics of included studies table. The following gives a brief overview of the comparisons between dietary interventions with an intention to reduce body weight and no dietary interventions to reduce body weight.

All eight included studies had a parallel and open design (Cohen 1991; Croft 1986; DISH 1985; Jalkanen 1991; ODES 1995; Ruvolo 1994; TAIM 1992; TONE 1998), and three of them had a factorial design (ODES 1995; TAIM 1992; TONE 1998). Four studies were performed as single-centre trials (Cohen 1991; Croft 1986; ODES 1995; Ruvolo 1994), and three did not mention any industry sponsoring (Cohen 1991; Jalkanen 1991; Ruvolo 1994).

\section{Participants and duration}

The included studies involved a total of 2100 hypertensive participants with a mean age of 45 to 66 years, a baseline systolic blood pressure of 128 to $178 \mathrm{~mm} \mathrm{Hg}$, and a baseline diastolic blood pressure of 72 to $107 \mathrm{~mm} \mathrm{Hg}$. Mean treatment duration was 6 to 36 months.

\section{Interventions}

In all studies, participants received either a dietary intervention with the aim of reducing body weight or no dietary intervention to reduce body weight.

\section{Outcomes}

\section{Primary outcomes}

Only one study included the occurrence of clinical cardiovascular disease complications during follow-up as a predefined outcome
(TONE 1998). Two studies reported adverse events (DISH 1985; TONE 1998).

\section{Secondary outcomes}

Except for three studies (Cohen 1991; DISH 1985; TONE 1998), all included studies described the mean change in systolic and diastolic blood pressure. All but one study, TONE 1998, described mean change in body weight.

\section{Excluded studies}

The main reason for exclusion was a lack of sufficient results for the hypertensive subgroup in studies including normotensive as well as hypertensive participants. We excluded some studies because they were not randomised controlled trials, did not include participants with essential hypertension, did not aim for weight reduction or examined a combined intervention, provided an inappropriate control intervention or different accompanying therapies, had a duration of intervention less than 24 weeks, or full text was not available. We excluded two studies after personal communication (Curzio 1989; Haynes 1984). Both studies were performed in the 1980s, and electronic records and/or hard copies were no longer available to further clarify whether the studies were suitable for inclusion in our review. We have provided reasons for excluding each trial in the Characteristics of excluded studies table.

\section{Risk of bias in included studies}

Our judgements of the risk of bias for all included studies are shown in the 'Risk of bias' summary figures (Figure 2; Figure 3). For details, see the 'Risk of bias' tables in Characteristics of included studies. The following gives a brief overview.

Figure 2. Risk of bias graph: review authors' judgements about each risk of bias item presented as percentages across all included studies.

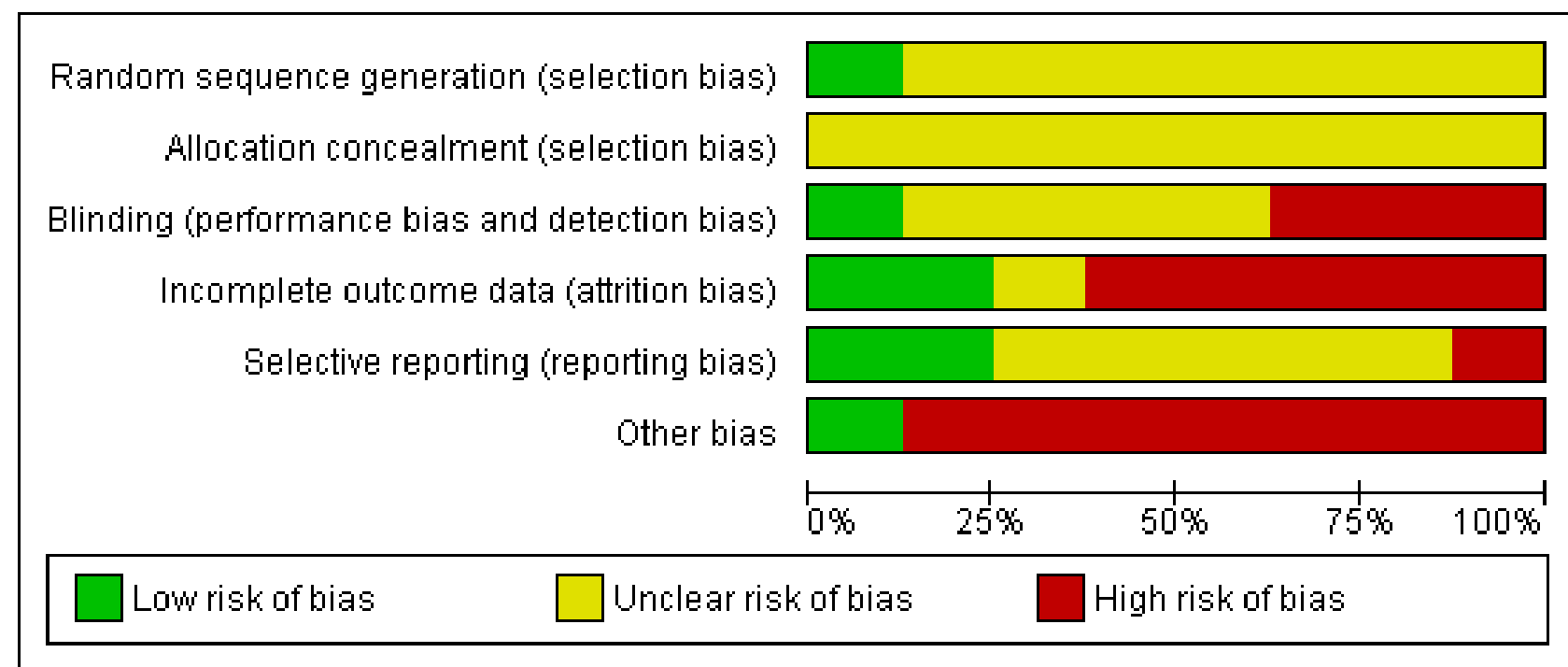


Figure 3. Risk of bias summary: review authors' judgements about each risk of bias item for each included study.

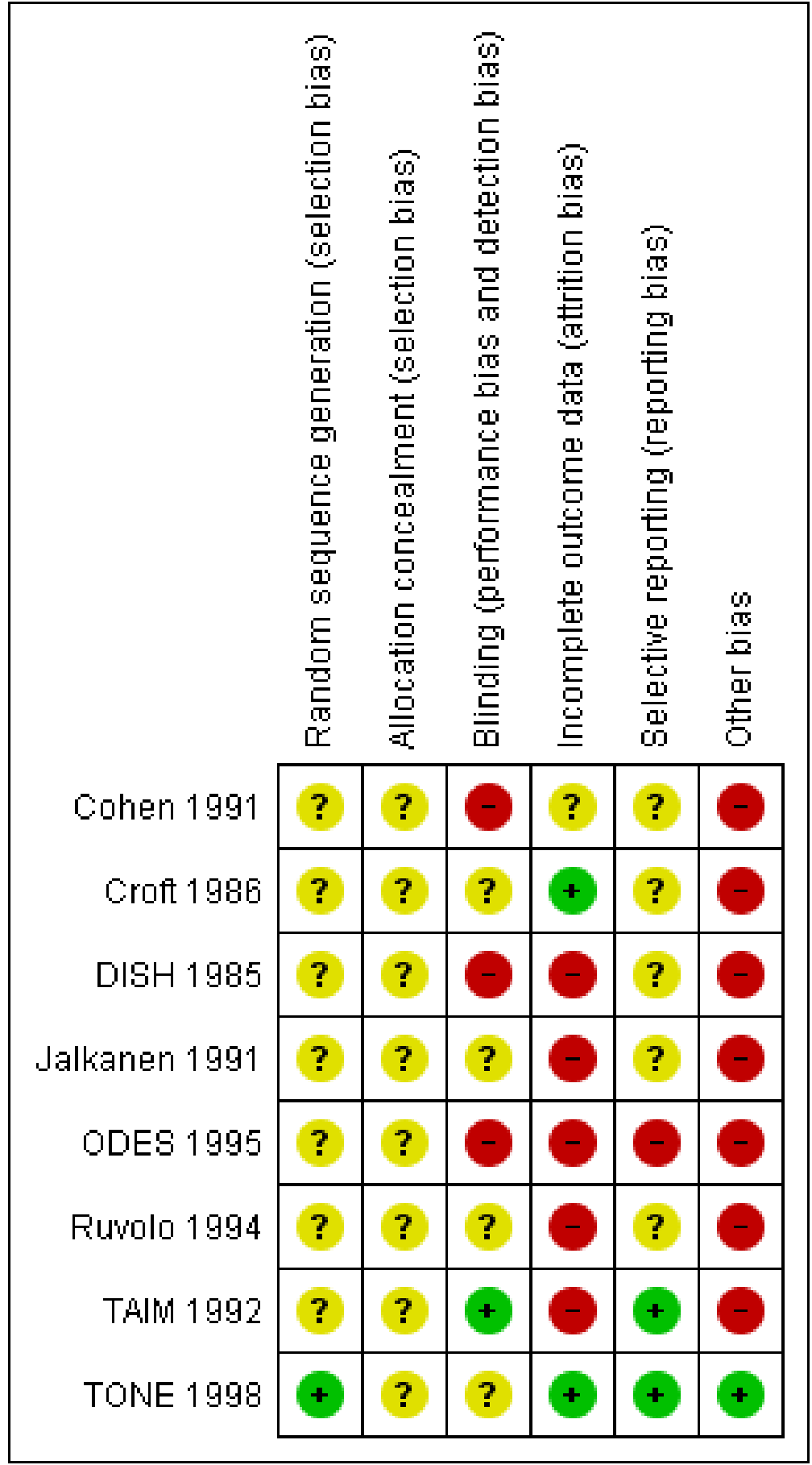

\section{Allocation}

Only two studies reported the method of randomisation (TAIM 1992; TONE 1998), and both of them had a factorial design. Only one study described the method of concealment (TAIM 1992). One study performed a cluster randomised trial in family practices (Cohen 1991), but without providing any information on allocation.

\section{Blinding}

All included trials had an open design in terms of participants and study personnel. In one study (TONE 1998), an independent committee masked to intervention assignment evaluated the endpoints. In another study (TAIM 1992), blood pressure endpoint assessment was blinded in only one out of three clinical centres due to logistical and budgetary considerations.

\section{Incomplete outcome data}

In one study (Cohen 1991), the description of the outcome data was complete because there were no losses to follow-up. In DISH 1985, no withdrawals were reported for the endpoint success of withdrawal from antihypertensive medication, but between $13 \%$ 
and $23 \%$ of values were missing for body weight at follow-up. In Jalkanen 1991 and Ruvolo 1994, only one to two participants were missing, but no reason for withdrawal was given. In TAIM 1992 and ODES 1995, study withdrawals were only reported for the whole study population, and no intention-to-treat analysis was performed. In TONE 1998, numbers of and reasons for withdrawals were missing, but $96 \%$ to $99 \%$ of participants were included in the follow-up analysis.

\section{Selective reporting}

There was a risk of selective reporting bias in one study in which post-hoc analyses of blood pressure were calculated, and results were not reported for all predefined outcomes (ODES 1995).

\section{Other potential sources of bias}

We could identify other potential sources of bias in all except one study (TONE 1998). One study featured stratified randomisation of investigators instead of participants, with very small cluster size (Cohen 1991). In another study (DISH 1985), participants were randomised before consent was obtained, and in two studies (Cohen 1991; TAIM 1992), treatment in the intervention group seemed to be more intensive. For further details, please see the 'Risk of bias' table and Figure 2 and Figure 3.

\section{Effects of interventions}

See: Summary of findings for the main comparison

See: Summary of findings for the main comparison

\section{Primary outcomes}

\section{Mortality}

None of the included studies was designed to evaluate the effects of weight loss diet versus no diet on mortality.

\section{Cardiovascular morbidity}

Only one study evaluated the effects of dietary weight loss intervention versus no dietary intervention, on a combined endpoint including cardiovascular complications (TONE 1998). After 30 months, the hazard ratio for participants in the dietary group to reach the combined endpoint, consisting of the necessity of reinstating antihypertensive therapy and severe cardiovascular complications, was 0.70 (95\% confidence interval (CI) 0.57 to 0.87 ) compared with participants in the usual-care group.

\section{Adverse events}

None of the included studies evaluated the endpoint adverse event as designed in our protocol (including total serious adverse events, withdrawal due to adverse events, and total non-serious adverse events).

TONE 1998 classified adverse events by type (primary cardiovascular events) and time of occurrence (before, during, or after attempted antihypertensive drug withdrawals). However, no usable results were reported for the obese subgroups with and without dietary interventions. DISH 1985 reported adverse events as withdrawals due to the need to resume antihypertensive medication; this was the case in $40.5 \%$ of participants in the intervention group and $64.7 \%$ of participants in the control group $(P=0.0015)$.

\section{Secondary outcomes}

For details on secondary outcome data, see Table 1, Table 2, and Table 3. Due to between-study variability, we have presented results from random-effects models in the following analyses.

\section{Changes in systolic blood pressure}

Five studies investigating the effects of dietary versus no dietary intervention could not be included in the meta-analysis for systolic blood pressure. In two studies (DISH 1985; TONE 1998), successful withdrawal from antihypertensives was the primary outcome. In another study (Cohen 1991), only the mean blood pressure change was reported, and in the studies of Ruvolo and Jalkanen (Jalkanen 1991; Ruvolo 1994), estimators for variance and $P$ values for the change in systolic blood pressure were missing. Therefore, only three studies remained for analysis; in the case of the TAIM study (TAIM 1992), the overall standard deviation (SD) presented for the combined analyses could be used for the meta-analysis. There was a significant reduction of systolic blood pressure with a mean difference (MD) of $-4.5 \mathrm{~mm} \mathrm{Hg}(95 \% \mathrm{Cl}-7.2$ to -1.8$)$ in favour of dietary intervention. The test of heterogeneity gave a $\mathrm{P}$ value of 0.3 , and Higgins 12 indicated only low heterogeneity between studies $(12=21 \%)$ (see Analysis 1.1; Figure 4). Differences in study quality could not explain heterogeneity. We could deduce no plausible explanation for heterogeneity from differences in study design, study duration, sample sizes, interventions, or characteristics of included participants.

Figure 4. Forest plot of comparison: 1 Weight-reducing diet versus no weight-reducing diet, outcome: 1.1 Change in systolic blood pressure from baseline to endpoint [ $\mathrm{mm} \mathrm{Hg}]$.

\begin{tabular}{|c|c|c|c|c|c|c|c|c|c|c|c|c|}
\hline Study or Subgroup & $\begin{array}{r}\text { Weight } r \\
\text { Mean }[\mathrm{mm} \mathrm{Hg}]\end{array}$ & $\begin{array}{l}\text { educing diet } \\
\text { SD [mm Hg] }\end{array}$ & Total & $\begin{array}{l}\text { No weight } \\
\text { Mean [mm Hg] }\end{array}$ & $\begin{array}{l}t \text { reducing diet } \\
\text { SD }[\mathrm{mm} \mathrm{Hg}]\end{array}$ & Total & Weight & $\begin{array}{c}\text { Mean Difference } \\
\text { IV, Random, } 95 \% \mathrm{CI}[\mathrm{mm} \mathrm{Hg}]\end{array}$ & \multicolumn{4}{|c|}{$\begin{array}{c}\text { Mean Difference } \\
\text { IV, Random, } 95 \% \mathrm{Cl}[\mathrm{mm} \mathrm{Hg}]\end{array}$} \\
\hline Croft 1986 & -11 & 15.26 & 66 & -4 & 15.26 & 64 & $21.5 \%$ & $-7.00[-12.25,-1.75]$ & & & & \\
\hline ODES 1995 no exercise & -8.4 & 13.2 & 16 & 2.9 & 15.24 & 12 & $6.0 \%$ & $-11.30[-22.08,-0.52]$ & & & & \\
\hline ODES 1995 with exercise & -8.3 & 10.29 & 24 & -4.1 & 8.05 & 20 & $20.4 \%$ & $-4.20[-9.62,1.22]$ & & & & \\
\hline TAIM 1992 combined & -17.01 & 15.95 & 265 & -14.22 & 15.95 & 264 & $52.2 \%$ & $-2.79[-5.51,-0.07]$ & & & & \\
\hline Total $(95 \% \mathrm{Cl})$ & & & 371 & & & 360 & $100.0 \%$ & $-4.49[-7.20,-1.78]$ & & & & \\
\hline $\begin{array}{l}\text { Heterogeneity: Tau }{ }^{2}=1 \\
\text { Test for overall effect: } Z=\end{array}$ & $\begin{array}{l}\mathrm{Chi}^{2}=3.78, \mathrm{df} \\
.25(\mathrm{P}=0.001)\end{array}$ & $=3(P=0.29$ & $\left.\right|^{2}=219$ & & & & & & $-\frac{1}{-20}$ & $\begin{array}{l}-10 \\
\text { Favours diet }\end{array}$ & $\begin{array}{l}10 \\
\text { Favours no diet }\end{array}$ & 20 \\
\hline
\end{tabular}

\section{Changes in diastolic blood pressure}

Five studies investigating the effects of dietary versus no dietary intervention could not be included in the meta-analysis for diastolic blood pressure. In two studies (DISH 1985; TONE 1998), successful withdrawal from antihypertensives was the primary outcome. In another study (Cohen 1991), only the mean blood pressure change was reported, and Jalkanen 1991 and Ruvolo 1994 do not include an estimator for variance and $P$ values for the change in diastolic blood pressure. Therefore, only three studies remained for analysis; 
in the case of the TAIM study (TAIM 1992), the SDs presented for the subgroup (atenolol, chlorthalidone, placebo) analyses could be used for the meta-analysis. There was a significant reduction of diastolic blood pressure with a MD of $-3.2 \mathrm{~mm} \mathrm{Hg}(95 \% \mathrm{Cl}-4.8$ to -1.5 ) in favour of dietary intervention. The test of heterogeneity gave a $\mathrm{P}$ value of $0.2\left(1^{2}=35 \%\right)$ (see Analysis 1.2; Figure 5). Differences in study quality could not explain heterogeneity. We could deduce no plausible explanation for heterogeneity from differences in study design, study duration, sample sizes, interventions, or characteristics of included participants.

\section{Figure 5. Forest plot of comparison: 1 Weight-reducing diet versus no weight-reducing diet, outcome: 1.2 Change in} diastolic blood pressure from baseline to endpoint $[\mathrm{mm} \mathrm{Hg}]$.

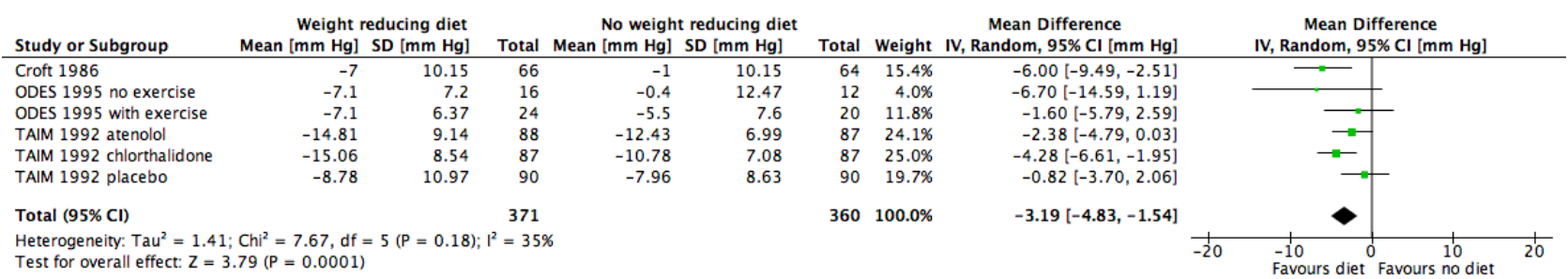

\section{Body weight}

Only three studies investigating the effects of dietary versus no dietary intervention could not be included in the meta-analysis for body weight. In two studies (ODES 1995; TONE 1998), no values for changes in body weight were presented, and in the study of Ruvolo (Ruvolo 1994), an estimator for variance and $P$ values for the change in body weight was missing. Therefore, five studies remained for analysis. In the TAIM study (TAIM 1992), we could use the SDs presented for the subgroup (atenolol, chlorthalidone, and placebo) analyses. Dietary intervention was found to lower body weight significantly more effectively with a MD of $-4.0 \mathrm{~kg}(95 \% \mathrm{Cl}-4.8$ to -3.2) in favour of dietary intervention. The test of heterogeneity gave a $\mathrm{P}$ value of $0.2\left(1^{2}=34 \%\right)$ (see Analysis 1.3; Figure 6). Differences in study quality could not explain heterogeneity. We could deduce no plausible explanation for heterogeneity from differences in study design, study duration, sample sizes, interventions, or characteristics of included participants.

Figure 6. Forest plot of comparison: 1 Weight-reducing diet versus no weight-reducing diet, outcome: 1.3 Change in body weight from baseline to endpoint $[\mathrm{kg}]$.

\begin{tabular}{|c|c|c|c|c|c|c|c|c|c|c|c|c|}
\hline Study or Subgroup & \multicolumn{3}{|c|}{ Weight reducing diet } & \multicolumn{3}{|c|}{ No weight reducing diet } & Weight & $\begin{array}{c}\text { Mean Difference } \\
\text { IV, Random, } 95 \% \mathrm{Cl}[\mathrm{kg}]\end{array}$ & \multicolumn{3}{|c|}{$\begin{array}{c}\text { Mean Difference } \\
\text { IV, Random, } 95 \% \mathrm{Cl}[\mathrm{kg}]\end{array}$} & \\
\hline Cohen 1991 & -0.88 & 4 & 15 & 1.3 & 3 & 15 & $8.3 \%$ & $-2.18[-4.71,0.35]$ & & 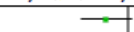 & & \\
\hline Croft 1986 & -6.5 & 10.66 & 66 & -0.2 & 10.66 & 64 & $4.4 \%$ & $-6.30[-9.97,-2.63]$ & & - & & \\
\hline DISH 1985 & -4 & 5 & 67 & -0.46 & 3.6 & 77 & $18.4 \%$ & $-3.54[-4.98,-2.10]$ & & 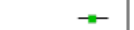 & & \\
\hline Jalkanen 1991 & -4 & 6.96 & 24 & 0 & 6.96 & 25 & $3.9 \%$ & $-4.00[-7.90,-0.10]$ & & & & \\
\hline TAIM 1992 atenolol & -3.02 & 3.75 & 88 & 0.53 & 2.8 & 87 & $27.0 \%$ & $-3.55[-4.53,-2.57]$ & & $=$ & & \\
\hline TAIM 1992 chlorthalidone & -6.85 & 4.64 & 86 & -1.52 & 3.73 & 87 & $21.5 \%$ & $-5.33[-6.59,-4.07]$ & & 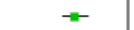 & & \\
\hline TAIM 1992 placebo & -4.41 & 6.6 & 89 & -0.71 & 3.79 & 90 & $16.5 \%$ & $-3.70[-5.28,-2.12]$ & & $\rightarrow$ & & \\
\hline Total $(95 \% \mathrm{Cl})$ & & & 435 & & & 445 & $100.0 \%$ & $-3.98[-4.79,-3.17]$ & & $\diamond$ & & \\
\hline $\begin{array}{l}\text { Heterogeneity: } \operatorname{Tau}^{2}=0.3 \\
\text { Test for overall effect: } Z=\end{array}$ & $\begin{array}{l}C \mathrm{Ch}^{2}=9.14 \\
.69(\mathrm{P}<0.0\end{array}$ & $\begin{array}{l}\mathrm{df}=6( \\
0001)\end{array}$ & $=0.17$ & $; 1^{2}=34 \%$ & & & & & $\frac{1}{-20}$ & $\begin{array}{l}1 \\
-10 \\
\text { Favours diet }\end{array}$ & $\begin{array}{c}10 \\
\text { Favours no die }\end{array}$ & 20 \\
\hline
\end{tabular}

\section{Subgroup analyses}

Not performed due to lack of data.

\section{Sensitivity analyses}

Not performed due to lack of data.

\section{Publication and small-study bias}

A clear interpretation of the funnel plot was not possible, which we mainly attributed to the relatively small number of included studies.

\section{DISCUSSION}

\section{Summary of main results}

This updated systematic review attempted to determine the longterm effects of weight loss through dietary interventions on patientrelevant endpoints, namely death, cardiovascular complications, and adverse events, in the antihypertensive therapy of people with essential hypertension. However, we found no currently available randomised controlled trials designed to answer this question. We identified no new studies as a result of the update and eight relevant trials that intended to reduce body weight (for example dietary counselling, caloric restrictions, reduction in fat intake) versus no dietary interventions. Of the eight included studies, only two were judged as having minor deficiencies of study quality (TAIM 1992; TONE 1998), while the other six studies have major deficiencies. Only one study reported on cardiovascular complications, as part of a combined primary outcome consisting of the necessity of reinstating antihypertensive therapy and severe cardiovascular complications, and was in favour of the dietaryintervention group (TONE 1998). No valuable information on adverse effects was reported in any publications on the relevant trials. The meta-analyses showed that participants under dietary therapy could reduce their systolic and diastolic blood pressure and body weight levels statistically significantly more than participants in the control groups. 
Two studies did not aim for blood pressure reduction, but used successful withdrawal of antihypertensive medication as primary outcomes (DISH 1985; TONE 1998). In DISH 1985, about 35\% of the participants in the control group and about $60 \%$ in the intervention group remained without antihypertensive medication after 56 weeks. In TONE 1998, 93\% of the participants in the weight loss group and $87 \%$ in the control group could stop antihypertensive treatment. In the salt-lowered groups, 93\% of both the dietary weight loss intervention and the usual-care group could successfully be taken off medication. Even though successful withdrawal of antihypertensive treatment was not included as a chosen outcome in our review, it further underscores the success of dietary weight loss interventions for reducing blood pressure.

In conclusion, in people with essential hypertension, therapy with dietary interventions to reduce body weight resulted in reductions in blood pressure and body weight. A reduction in body weight of approximately $4 \mathrm{~kg}$ was necessary to achieve a reduction of approximately $4.5 \mathrm{~mm} \mathrm{Hg}$ systolic blood pressure and approximately $3.2 \mathrm{~mm} \mathrm{Hg}$ diastolic blood pressure. However, the fact that only some of the studies could be included in the analyses weakens our conclusion. None of the studies provided data to answer the question of whether weight reduction can lower the risk of mortality or other patient-relevant endpoints.

\section{Overall completeness and applicability of evidence}

We searched four electronic databases and the clinical trials registry ClinicalTrials.gov until 2 February 2015. We also searched the reference lists of included trials and relevant systematic reviews and meta-analyses. We assessed the quality of each study and summarised the results. The results of this review can therefore be taken to be complete and applicable. For full information, please see details in the relevant sections.

While the results of this review show that dietary interventions may be helpful in the antihypertensive therapy of overweight hypertensive patients, major questions still remain. One point raised by Brian Haynes, a co-author we contacted for further clarification on whether his paper was relevant for inclusion in the review, was whether any effect on blood pressure lowering persists when the patient's period of active weight loss ends. His clinical impression is that when weight loss stops (even if the weight loss is maintained?), the blood pressure goes back up (Haynes 2010 [pers comm]). However, as we could identify no long-term followup trials for our review, the long-term effects of weight loss on blood pressure are uncertain. Indirect evidence from this assumption can be derived from the Swedish Obese Subject Study (Sjostrom 2004), where participants successfully reduced their body weight by means of bariatric surgery. This study showed that the postsurgical blood pressure reduction was still present 2 years after surgery, but increased again to baseline values after 10 years, despite continued weight loss. Secondly, it can be asked whether people with higher or lower blood pressure or higher or lower body weight at baseline might benefit in a different way from dietary intervention aiming to reduce body weight. It can, however, be assumed that the potential benefit on blood pressure might be greater in people with moderate to severe hypertension than in people with mild hypertension; in any case, no correlation could be identified from the included studies.

\section{Quality of the evidence}

Of the eight studies included in our analyses, we judged only two as having minor deficiencies of quality (TAIM 1992; TONE 1998). All other studies have to be judged as having major deficiencies. Therefore, the beneficial effects shown reflect some degree of uncertainty. We have provided full details in the 'Risk of bias' tables in Characteristics of included studies.

\section{Potential biases in the review process}

A major limitation of this review is that due to the lack of information in the included studies, we could draw no conclusions on the effects of the different dietary weight loss interventions on patient-relevant long-term outcomes.

The results for the change in blood pressure outcomes could also be considered uncertain as data from only three studies were included in the analyses. These results were mainly based on the TAIM 1992 study, which we judged to have a low risk of bias and contributed more than $70 \%$ of all participants to the meta-analyses. In addition, two of the trials that did not report results on blood pressure showed a reduction of antihypertensive medication as an indirect measure of blood pressure, which supports the findings of our meta-analyses. Furthermore, inclusion of the remaining studies from which data on blood pressure were available but were insufficient would probably not have changed the results because these studies were all small and rated as at high risk of bias.

The findings on body weight may also be regarded as uncertain as results from only five studies were available for the analysis. Again, the TAIM 1992 study had the highest weight in the analysis. These results are supported by results from the ODES 1995 study, which did not report on body weight, but found body mass index to be reduced to a greater extent among participants in the intervention groups.

\section{Agreements and disagreements with other studies or reviews}

There are only a few published systematic reviews on long-term effects of weight-reducing diets in people with hypertension. One systematic review, 'Effects of Weight Loss in Overweight/Obese Individuals and Long-Term Hypertension Outcomes', published by Aucott (Aucott 2005), reached the same conclusion, that is that only short-term trials were available. The authors also warned "that extrapolation of short-term blood pressure changes with weight loss to the longer term is potentially misleading. The weight/ hypertension relationship is complex and needs well-conducted studies with long-term follow-up to examine the effects of weight loss on hypertension outcomes". In addition, we were involved in the preparation of the scientific report on the evaluation of the benefits and harms of non-drug treatment strategies in people with essential hypertension (IQWiG 2006), and published a paper on this topic in 2008 (Horvath 2008). Since our last search for dietary interventions performed on 22 November 2010 (Siebenhofer 2011), we could identify no new trials addressing our research question. We can therefore say with confidence that our findings are in agreement with other published reviews and studies in this field. 


\section{AUTHORS' CONCLUSIONS}

\section{Implications for practice}

Although trials on dietary interventions in people with elevated blood pressure demonstrated statistically significant decreases in weight loss and blood pressure, these findings are subject to a high risk of selective reporting bias. Furthermore, the available randomised controlled trial evidence provided no data on the effect of dietary interventions on mortality and morbidity, and none of the included trials reported valuable information on adverse events.

\section{Implications for research}

Long-term trials assessing the effect of dietary interventions to reduce body weight on mortality, morbidity, and adverse events in people with elevated blood pressure are needed. Long-term followup data are also needed to determine the long-term effects of weight-reducing diets on blood pressure.

\section{A C K N OWLEDGEMENTS}

The review authors would like to acknowledge the contributions of Jutta Meschik in reviewing the data and Douglas Salzwedel for assisting in updating the literature search for the 2015 update of this review.

The review authors would like to acknowledge the contributions of Eva Matyas, Nicole Pignitter, and Anika Maas in reviewing the data and the contribution of Eugenia Lamont in the final editing of the manuscript for the 2011 version of this review.

The review authors would like to acknowledge the contributions of Andreas Waltering, Lars Hemkens, Christoph Pachler, and Reinhard Strametz in the selection of studies, quality assessment of trials, data extraction, and development of the final 2011 version of this review. 


\section{R E F E E N CE S}

\section{References to studies included in this review}

Cohen 1991 \{published data only\}

Cohen MD, D'Amico FJ, Merenstein JH. Weight reduction in obese hypertensive patients. Family Medicine 1991;23(1):25-8. [PUBMED: 2001777]

\section{Croft 1986 \{published data only\}}

Croft PR, Brigg D, Smith S, Harrison CB, Branthwaite A, Collins MF. How useful is weight reduction in the management of hypertension?. The Journal of the Royal College of General Practitioners 1986;36(291):445-8. [PUBMED: 3440987]

\section{DISH 1985 \{published data only\}}

Blaufox MD, Langford HG, Oberman A, Hawkins CM, Wassertheil-Smoller SW, Cutter GR. Effect of dietary change on the return of hypertension after withdrawal of prolonged antihypertensive therapy (DISH). Dietary Intervention Study of Hypertension. Journal of Hypertension. Supplement: Official Journal of the International Society of Hypertension 1984;2(3):S179-81. [PUBMED: 6599665]

* Langford HG, Blaufox MD, Oberman A, Hawkins CM, Curb JD, Cutter GR, et al. Dietary therapy slows the return of hypertension after stopping prolonged medication. JAMA 1985;253(5):657-64. [PUBMED: 3881608]

Langford HG, Blaufox MD, Oberman A, Hawkins CM, Curb JD, Cutter GR, et al. Return of hypertension after withdrawal of prolonged antihypertensive therapy, effect of weight loss, sodium reduction, and baseline factors. Transactions of the Association of American Physicians 1984;97:190-6. [PUBMED: 6535339]

\section{Jalkanen 1991 \{published data only\}}

Jalkanen $\mathrm{L}$. The effect of a weight reduction program on cardiovascular risk factors among overweight hypertensives in primary health care. Scandinavian Journal of Social Medicine 1991;19(1):66-71. [PUBMED: 1925430]

\section{ODES 1995 \{published data only\}}

* Anderssen S, Holme I, Urdal P, Hjermann I. Diet and exercise intervention have favourable effects on blood pressure in mild hypertensives: the Oslo Diet and Exercise Study (ODES). Blood Pressure 1995;4(6):343-9. [PUBMED: 8746601]

Anderssen SA, Hjermann I, Urdal P, Torjesen PA, Holme I. Improved carbohydrate metabolism after physical training and dietary intervention in individuals with the 'atherothrombogenic syndrome'. Oslo Diet and Exercise Study (ODES). A randomized trial. Journal of Internal Medicine 1996;240(4):203-9. [PUBMED: 8918511]

Jacobs DR Jr, Sluik D, Rokling-Andersen MH, Anderssen SA, Drevon CA. Association of 1-y changes in diet pattern with cardiovascular disease risk factors and adipokines: results from the 1-y randomized Oslo Diet and Exercise Study. The American Journal of Clinical Nutrition 2009;89:509-17. [PUBMED: 19116328]
Torjesen PA, Birkeland KI, Anderssen SA, Hjermann I, Holme I, Urdal P. Lifestyle changes may reverse development of the insulin resistance syndrome. The Oslo Diet and Exercise Study: a randomized trial. Diabetes Care 1997;20(1):26-31. [PUBMED: 9028689]

Urdal P, Haaland A, Hjermann I, Gjesdal K, Christian C, Sorensen M, et al. The Oslo Diet and Exercise Study (ODES): Design and objectives. Controlled Clinical Trials 1993;14(3):229-43.

\section{ODES 1995 no exercise \{published data only\}}

* Anderssen S, Holme I, Urdal P, Hjermann I. Diet and exercise intervention have favourable effects on blood pressure in mild hypertensives: the Oslo Diet and Exercise Study (ODES). Blood Pressure 1995;4(6):343-9. [PUBMED: 8746601]

Anderssen SA, Hjermann I, Urdal P, Torjesen PA, Holme I. Improved carbohydrate metabolism after physical training and dietary intervention in individuals with the 'atherothrombogenic syndrome'. Oslo Diet and Exercise Study (ODES). A randomized trial. Journal of Internal Medicine 1996;240(4):203-9. [PUBMED: 8918511]

Jacobs DR Jr, Sluik D, Rokling-Andersen MH, Anderssen SA, Drevon CA. Association of 1-y changes in diet pattern with cardiovascular disease risk factors and adipokines: results from the 1-y randomized Oslo Diet and Exercise Study. The American Journal of Clinical Nutrition 2009;89:509-17. [PUBMED: 19116328]

Torjesen PA, Birkeland KI, Anderssen SA, Hjermann I, Holme I, Urdal P. Lifestyle changes may reverse development of the insulin resistance syndrome. The Oslo Diet and Exercise Study: a randomized trial. Diabetes Care 1997;20(1):26-31. [PUBMED: 9028689]

Urdal P, Haaland A, Hjermann I, Gjesdal K, Christian C, Sorensen M, et al. The Oslo Diet and Exercise Study (ODES): Design and objectives. Controlled Clinical Trials 1993;14(3):229-43.

ODES 1995 with exercise \{published data only\}

* Anderssen S, Holme I, Urdal P, Hjermann I. Diet and exercise intervention have favourable effects on blood pressure in mild hypertensives: the Oslo Diet and Exercise Study (ODES). Blood Pressure 1995;4(6):343-9. [PUBMED: 8746601]

Anderssen SA, Hjermann I, Urdal P, Torjesen PA, Holme I. Improved carbohydrate metabolism after physical training and dietary intervention in individuals with the 'atherothrombogenic syndrome'. Oslo Diet and Exercise Study (ODES). A randomized trial. Journal of Internal Medicine 1996;240(4):203-9. [PUBMED: 8918511]

Jacobs DR Jr, Sluik D, Rokling-Andersen MH, Anderssen SA, Drevon CA. Association of 1-y changes in diet pattern with cardiovascular disease risk factors and adipokines: results from the 1-y randomized Oslo Diet and Exercise Study. The American Journal of Clinical Nutrition 2009;89:509-17. [PUBMED: 19116328] 
Torjesen PA, Birkeland KI, Anderssen SA, Hjermann I, Holme I, Urdal P. Lifestyle changes may reverse development of the insulin resistance syndrome. The Oslo Diet and Exercise Study: a randomized trial. Diabetes Care 1997;20(1):26-31. [PUBMED: 9028689]

Urdal P, Haaland A, Hjermann I, Gjesdal K, Christian C, Sorensen M, et al. The Oslo Diet and Exercise Study (ODES): Design and objectives. Controlled Clinical Trials 1993;14(3):229-43.

\section{Ruvolo 1994 \{published data only\}}

Ruvolo G, Greco E, Speziale G, Di Natale M, Marino B. The effect on left ventricular mass of treatment with amlodipine and diet therapy in obese patients with arterial hypertension [Effetti sulla massa ventricolare sinistra del trattamento con amlodipina e dietoterapia in pazienti obesi affetti da ipertensione arteriosa.]. Minerva Cardioangiologica 1994;42(6):289-92. [PUBMED: 7936332]

\section{TAIM 1992 \{published data only\}}

Blaufox MD, Lee HB, Davis B, Oberman A, Wassertheil-Smoller S, Langford $\mathrm{H}$. Renin predicts diastolic blood pressure response to nonpharmacologic and pharmacologic therapy. JAMA 1992;267(9):1221-5. [PUBMED: 1538559]

Davis BR, Blaufox MD, Hawkins CM, Langford HG, Oberman A, Swencionis $C$, et al. Trial of antihypertensive interventions and management. Design, methods, and selected baseline results. Controlled Clinical Trials 1989;10(1):11-30. [PUBMED: 2649308]

* Davis BR, Blaufox MD, Oberman A, Wassertheil-Smoller S, Zimbaldi N, Cutler JA, et al. Reduction in long-term antihypertensive medication requirements. Effects of weight reduction by dietary intervention in overweight persons with mild hypertension. Archives of Internal Medicine 1993;153(15):1773-82. [PUBMED: 8333814]

Davis BR, Oberman A, Blaufox MD, Wassertheil-Smoller S, Hawkins CM, Cutler JA, et al. Effect of antihypertensive therapy on weight loss. The Trial of Antihypertensive Interventions and Management Research Group. Hypertension 1992;19(4):393-9. [PUBMED: 1555871]

Davis BR, Oberman A, Blaufox MD, Wassertheil-Smoller S, Zimbaldi N, Kirchner K, et al. Lack of effectiveness of a lowsodium/high-potassium diet in reducing antihypertensive medication requirements in overweight persons with mild hypertension. TAIM Research Group. Trial of Antihypertensive Interventions and Management. American Journal of Hypertension 1994;7(10 Pt 1):926-32. [PUBMED: 7826557]

Langford HG, Davis BR, Blaufox D, Oberman A, WassertheilSmoller S, Hawkins M, et al. Effect of drug and diet treatment of mild hypertension on diastolic blood pressure. The TAIM Research Group. Hypertension 1991;17(2):210-7. [PUBMED: 1671380]

Oberman A, Wassertheil-Smoller S, Langford HG, Blaufox MD, Davis BR, Blaszkowski T, et al. Pharmacologic and nutritional treatment of mild hypertension: changes in cardiovascular risk status. Annals of Internal Medicine 1990;112(2):89-95. [PUBMED: 1967210]
Wassertheil-Smoller S, Blaufox MD, Davis BR, Kirchner K, Langford HG, Oberman A. The trial of antihypertensive interventions and management (TAIM). Nieren- und Hochdruckkrankheiten 1994;23 (Suppl 1):S22-7.

Wassertheil-Smoller S, Blaufox MD, Oberman AS, Langford HG, Davis BR, Wylie-Rosett J. The Trial of Antihypertensive Interventions and Management (TAIM) study. Adequate weight loss, alone and combined with drug therapy in the treatment of mild hypertension. Archives of Internal Medicine 1992;152(1):131-6. [PUBMED: 1728908]

Wassertheil-Smoller S, Davis BR, Oberman A. The TAIM Study: Sex-race differences in effects of diet and drugs on cardiovascular risk. Cardiovascular Risk Factors 1991;1(7):427-35.

Wassertheil-Smoller S, Oberman A, Blaufox MD, Davis B, Langford $\mathrm{H}$. The Trial of Antihypertensive Interventions and Management (TAIM) Study. Final results with regard to blood pressure, cardiovascular risk, and quality of life. American Journal of Hypertension 1992;5(1):37-44. [PUBMED: 1736933]

Wylie-Rosett J, Wassertheil-Smoller S, Blaufox MD, Davis BR, Langford HG, Oberman A, et al. Trial of antihypertensive intervention and management: greater efficacy with weight reduction than with a sodium-potassium intervention. Journal of the American Dietetic Association 1993;93(4):408-15. [PUBMED: 8454808]

\section{TAIM 1992 atenolol \{published data only\}}

Blaufox MD, Lee HB, Davis B, Oberman A, Wassertheil-Smoller S, Langford $\mathrm{H}$. Renin predicts diastolic blood pressure response to nonpharmacologic and pharmacologic therapy. JAMA 1992;267(9):1221-5. [PUBMED: 1538559]

Davis BR, Blaufox MD, Hawkins CM, Langford HG, Oberman A, Swencionis $C$, et al. Trial of antihypertensive interventions and management. Design, methods, and selected baseline results. Controlled Clinical Trials 1989;10(1):11-30. [PUBMED: 2649308]

* Davis BR, Blaufox MD, Oberman A, Wassertheil-Smoller S, Zimbaldi N, Cutler JA, et al. Reduction in long-term antihypertensive medication requirements. Effects of weight reduction by dietary intervention in overweight persons with mild hypertension. Archives of Internal Medicine 1993;153(15):1773-82. [PUBMED: 8333814]

Davis BR, Oberman A, Blaufox MD, Wassertheil-Smoller S, Hawkins CM, Cutler JA, et al. Effect of antihypertensive therapy on weight loss. The Trial of Antihypertensive Interventions and Management Research Group. Hypertension 1992;19(4):393-9. [PUBMED: 1555871]

Davis BR, Oberman A, Blaufox MD, Wassertheil-Smoller S, Zimbaldi N, Kirchner K, et al. Lack of effectiveness of a lowsodium/high-potassium diet in reducing antihypertensive medication requirements in overweight persons with mild hypertension. TAIM Research Group. Trial of Antihypertensive Interventions and Management. American Journal of Hypertension 1994;7(10 Pt 1):926-32. [PUBMED: 7826557]

Langford HG, Davis BR, Blaufox D, Oberman A, WassertheilSmoller S, Hawkins M, et al. Effect of drug and diet treatment 
of mild hypertension on diastolic blood pressure. The TAIM Research Group. Hypertension 1991;17(2):210-7. [PUBMED: 1671380]

Oberman A, Wassertheil-Smoller S, Langford HG, Blaufox MD, Davis BR, Blaszkowski T, et al. Pharmacologic and nutritional treatment of mild hypertension: changes in cardiovascular risk status. Annals of Internal Medicine 1990;112(2):89-95. [PUBMED: 1967210]

Wassertheil-Smoller S, Blaufox MD, Davis BR, Kirchner K, Langford HG, Oberman A. The trial of antihypertensive interventions and management (TAIM). Nieren- und Hochdruckkrankheiten 1994;23 (Suppl 1):S22-7.

Wassertheil-Smoller S, Blaufox MD, Oberman AS, Langford HG, Davis BR, Wylie-Rosett J. The Trial of Antihypertensive Interventions and Management (TAIM) study. Adequate weight loss, alone and combined with drug therapy in the treatment of mild hypertension. Archives of Internal Medicine 1992;152(1):131-6. [PUBMED: 1728908]

Wassertheil-Smoller S, Davis BR, Oberman A. The TAIM Study: Sex-race differences in effects of diet and drugs on cardiovascular risk. Cardiovascular Risk Factors 1991;1(7):427-35.

Wassertheil-Smoller S, Oberman A, Blaufox MD, Davis B, Langford $\mathrm{H}$. The Trial of Antihypertensive Interventions and Management (TAIM) Study. Final results with regard to blood pressure, cardiovascular risk, and quality of life. American Journal of Hypertension 1992;5(1):37-44. [PUBMED: 1736933]

Wylie-Rosett J, Wassertheil-Smoller S, Blaufox MD, Davis BR, Langford HG, Oberman A, et al. Trial of antihypertensive intervention and management: greater efficacy with weight reduction than with a sodium-potassium intervention. Journal of the American Dietetic Association 1993;93(4):408-15. [PUBMED: 8454808]

\section{TAIM 1992 chlorthalidone \{published data only\}}

Blaufox MD, Lee HB, Davis B, Oberman A, Wassertheil-Smoller S, Langford $\mathrm{H}$. Renin predicts diastolic blood pressure response to nonpharmacologic and pharmacologic therapy. JAMA 1992;267(9):1221-5. [PUBMED: 1538559]

Davis BR, Blaufox MD, Hawkins CM, Langford HG, Oberman A, Swencionis $C$, et al. Trial of antihypertensive interventions and management. Design, methods, and selected baseline results. Controlled Clinical Trials 1989;10(1):11-30. [PUBMED: 2649308]

* Davis BR, Blaufox MD, Oberman A, Wassertheil-Smoller S, Zimbaldi N, Cutler JA, et al. Reduction in long-term antihypertensive medication requirements. Effects of weight reduction by dietary intervention in overweight persons with mild hypertension. Archives of Internal Medicine 1993;153(15):1773-82. [PUBMED: 8333814]

Davis BR, Oberman A, Blaufox MD, Wassertheil-Smoller S, Hawkins CM, Cutler JA, et al. Effect of antihypertensive therapy on weight loss. The Trial of Antihypertensive Interventions and Management Research Group. Hypertension 1992;19(4):393-9. [PUBMED: 1555871]
Davis BR, Oberman A, Blaufox MD, Wassertheil-Smoller S, Zimbaldi N, Kirchner K, et al. Lack of effectiveness of a lowsodium/high-potassium diet in reducing antihypertensive medication requirements in overweight persons with mild hypertension. TAIM Research Group. Trial of Antihypertensive Interventions and Management. American Journal of Hypertension 1994;7(10 Pt 1):926-32. [PUBMED: 7826557]

Langford HG, Davis BR, Blaufox D, Oberman A, WassertheilSmoller S, Hawkins M, et al. Effect of drug and diet treatment of mild hypertension on diastolic blood pressure. The TAIM Research Group. Hypertension 1991;17(2):210-7. [PUBMED: 1671380]

Oberman A, Wassertheil-Smoller S, Langford HG, Blaufox MD, Davis BR, Blaszkowski T, et al. Pharmacologic and nutritional treatment of mild hypertension: changes in cardiovascular risk status. Annals of Internal Medicine 1990;112(2):89-95. [PUBMED: 1967210]

Wassertheil-Smoller S, Blaufox MD, Davis BR, Kirchner K, Langford HG, Oberman A. The trial of antihypertensive interventions and management (TAIM). Nieren- und Hochdruckkrankheiten 1994;23 (Suppl 1):S22-7.

Wassertheil-Smoller S, Blaufox MD, Oberman AS, Langford HG, Davis BR, Wylie-Rosett J. The Trial of Antihypertensive Interventions and Management (TAIM) study. Adequate weight loss, alone and combined with drug therapy in the treatment of mild hypertension. Archives of Internal Medicine 1992;152(1):131-6. [PUBMED: 1728908]

Wassertheil-Smoller S, Davis BR, Oberman A. The TAIM Study: Sex-race differences in effects of diet and drugs on cardiovascular risk. Cardiovascular Risk Factors 1991;1(7):427-35.

Wassertheil-Smoller S, Oberman A, Blaufox MD, Davis B, Langford $\mathrm{H}$. The Trial of Antihypertensive Interventions and Management (TAIM) Study. Final results with regard to blood pressure, cardiovascular risk, and quality of life. American Journal of Hypertension 1992;5(1):37-44. [PUBMED: 1736933]

Wylie-Rosett J, Wassertheil-Smoller S, Blaufox MD, Davis BR, Langford HG, Oberman A, et al. Trial of antihypertensive intervention and management: greater efficacy with weight reduction than with a sodium-potassium intervention. Journal of the American Dietetic Association 1993;93(4):408-15. [PUBMED: 8454808]

\section{TAIM 1992 combined \{published data only\}}

Blaufox MD, Lee HB, Davis B, Oberman A, Wassertheil-Smoller S, Langford $\mathrm{H}$. Renin predicts diastolic blood pressure response to nonpharmacologic and pharmacologic therapy. JAMA 1992;267(9):1221-5. [PUBMED: 1538559]

Davis BR, Blaufox MD, Hawkins CM, Langford HG, Oberman A, Swencionis $C$, et al. Trial of antihypertensive interventions and management. Design, methods, and selected baseline results. Controlled Clinical Trials 1989;10(1):11-30. [PUBMED: 2649308]

* Davis BR, Blaufox MD, Oberman A, Wassertheil-Smoller S, Zimbaldi N, Cutler JA, et al. Reduction in long-term antihypertensive medication requirements. Effects of 
weight reduction by dietary intervention in overweight persons with mild hypertension. Archives of Internal Medicine 1993;153(15):1773-82. [PUBMED: 8333814]

Davis BR, Oberman A, Blaufox MD, Wassertheil-Smoller S, Hawkins CM, Cutler JA, et al. Effect of antihypertensive therapy on weight loss. The Trial of Antihypertensive Interventions and Management Research Group. Hypertension 1992;19(4):393-9. [PUBMED: 1555871]

Davis BR, Oberman A, Blaufox MD, Wassertheil-Smoller S, Zimbaldi N, Kirchner K, et al. Lack of effectiveness of a lowsodium/high-potassium diet in reducing antihypertensive medication requirements in overweight persons with mild hypertension. TAIM Research Group. Trial of Antihypertensive Interventions and Management. American Journal of Hypertension 1994;7(10 Pt 1):926-32. [PUBMED: 7826557]

Langford HG, Davis BR, Blaufox D, Oberman A, WassertheilSmoller S, Hawkins M, et al. Effect of drug and diet treatment of mild hypertension on diastolic blood pressure. The TAIM Research Group. Hypertension 1991;17(2):210-7. [PUBMED: 1671380]

Oberman A, Wassertheil-Smoller S, Langford HG, Blaufox MD, Davis BR, Blaszkowski T, et al. Pharmacologic and nutritional treatment of mild hypertension: changes in cardiovascular risk status. Annals of Internal Medicine 1990;112(2):89-95. [PUBMED: 1967210]

Wassertheil-Smoller S, Blaufox MD, Davis BR, Kirchner K, Langford HG, Oberman A. The trial of antihypertensive interventions and management (TAIM). Nieren- und Hochdruckkrankheiten 1994;23 (Suppl 1):S22-7.

Wassertheil-Smoller S, Blaufox MD, Oberman AS, Langford HG, Davis BR, Wylie-Rosett J. The Trial of Antihypertensive Interventions and Management (TAIM) study. Adequate weight loss, alone and combined with drug therapy in the treatment of mild hypertension. Archives of Internal Medicine 1992;152(1):131-6. [PUBMED: 1728908]

Wassertheil-Smoller S, Davis BR, Oberman A. The TAIM Study: Sex-race differences in effects of diet and drugs on cardiovascular risk. Cardiovascular Risk Factors 1991;1(7):427-35.

Wassertheil-Smoller S, Oberman A, Blaufox MD, Davis B, Langford $\mathrm{H}$. The Trial of Antihypertensive Interventions and Management (TAIM) Study. Final results with regard to blood pressure, cardiovascular risk, and quality of life. American Journal of Hypertension 1992;5(1):37-44. [PUBMED: 1736933]

Wylie-Rosett J, Wassertheil-Smoller S, Blaufox MD, Davis BR, Langford HG, Oberman A, et al. Trial of antihypertensive intervention and management: greater efficacy with weight reduction than with a sodium-potassium intervention. Journal of the American Dietetic Association 1993;93(4):408-15. [PUBMED: 8454808]

\section{TAIM 1992 placebo \{published data only\}}

Blaufox MD, Lee HB, Davis B, Oberman A, Wassertheil-Smoller S, Langford $\mathrm{H}$. Renin predicts diastolic blood pressure response to nonpharmacologic and pharmacologic therapy. JAMA 1992;267(9):1221-5. [PUBMED: 1538559]

Davis BR, Blaufox MD, Hawkins CM, Langford HG, Oberman A, Swencionis $C$, et al. Trial of antihypertensive interventions and management. Design, methods, and selected baseline results. Controlled Clinical Trials 1989;10(1):11-30. [PUBMED: 2649308]

* Davis BR, Blaufox MD, Oberman A, Wassertheil-Smoller S, Zimbaldi N, Cutler JA, et al. Reduction in long-term antihypertensive medication requirements. Effects of weight reduction by dietary intervention in overweight persons with mild hypertension. Archives of Internal Medicine 1993;153(15):1773-82. [PUBMED: 8333814]

Davis BR, Oberman A, Blaufox MD, Wassertheil-Smoller S, Hawkins CM, Cutler JA, et al. Effect of antihypertensive therapy on weight loss. The Trial of Antihypertensive Interventions and Management Research Group. Hypertension 1992;19(4):393-9. [PUBMED: 1555871]

Davis BR, Oberman A, Blaufox MD, Wassertheil-Smoller S, Zimbaldi N, Kirchner K, et al. Lack of effectiveness of a lowsodium/high-potassium diet in reducing antihypertensive medication requirements in overweight persons with mild hypertension. TAIM Research Group. Trial of Antihypertensive Interventions and Management. American Journal of Hypertension 1994;7(10 Pt 1):926-32. [PUBMED: 7826557]

Langford HG, Davis BR, Blaufox D, Oberman A, WassertheilSmoller S, Hawkins M, et al. Effect of drug and diet treatment of mild hypertension on diastolic blood pressure. The TAIM Research Group. Hypertension 1991;17(2):210-7. [PUBMED: 1671380]

Oberman A, Wassertheil-Smoller S, Langford HG, Blaufox MD, Davis BR, Blaszkowski T, et al. Pharmacologic and nutritional treatment of mild hypertension: changes in cardiovascular risk status. Annals of Internal Medicine 1990;112(2):89-95. [PUBMED: 1967210]

Wassertheil-Smoller S, Blaufox MD, Davis BR, Kirchner K, Langford HG, Oberman A. The trial of antihypertensive interventions and management (TAIM). Nieren- und Hochdruckkrankheiten 1994;23 (Suppl 1):S22-7.

Wassertheil-Smoller S, Blaufox MD, Oberman AS, Langford HG, Davis BR, Wylie-Rosett J. The Trial of Antihypertensive Interventions and Management (TAIM) study. Adequate weight loss, alone and combined with drug therapy in the treatment of mild hypertension. Archives of Internal Medicine 1992;152(1):131-6. [PUBMED: 1728908]

Wassertheil-Smoller S, Davis BR, Oberman A. The TAIM Study: Sex-race differences in effects of diet and drugs on cardiovascular risk. Cardiovascular Risk Factors 1991;1(7):427-35.

Wassertheil-Smoller S, Oberman A, Blaufox MD, Davis B, Langford $H$. The Trial of Antihypertensive Interventions and Management (TAIM) Study. Final results with regard to blood pressure, cardiovascular risk, and quality of life. American Journal of Hypertension 1992;5(1):37-44. [PUBMED: 1736933] 
Wylie-Rosett J, Wassertheil-Smoller S, Blaufox MD, Davis BR, Langford HG, Oberman A, et al. Trial of antihypertensive intervention and management: greater efficacy with weight reduction than with a sodium-potassium intervention. Journal of the American Dietetic Association 1993;93(4):408-15. [PUBMED: 8454808]

\section{TONE 1998 \{published data only\}}

Appel LJ, Espeland M, Whelton PK, Dolecek T, Kumanyika S, Applegate WB, et al. Trial of Nonpharmacologic Intervention in the Elderly (TONE). Design and rationale of a blood pressure control trial. Annals of Epidemiology 1995;5(2):119-29. [PUBMED: 7795830]

Bahnson JL, Whelton PK, Appel LJ, Espeland MA, Wofford JL, Rosen $\mathrm{R}$, et al. Baseline characteristics of randomized participants in the trial of nonpharmacologic intervention in the elderly (TONE). Disease Management \& Clinical Outcomes 1997;1(2):61-8.

Espeland MA, Whelton PK, Kostis JB, Bahnson JL, Ettinger WH, Cutler JA, et al. Predictors and mediators of successful longterm withdrawal from antihypertensive medications. Archives of Family Medicine 1999;8(3):228-36. [PUBMED: 10333818]

Fessler B. Sodium reduction and weight loss instead of treatment with antihypertensive agents. [German]. Deutsche Apotheker Zeitung 1998;138(26):36-9.

Kostis JB, Wilson AC, Shindler DM, Cosgrove NM, Lacy CR. Persistence of normotension after discontinuation of lifestyle intervention in the trial of TONE. Trial of Nonpharmacologic Interventions in the Elderly. American Journal of Hypertension 2002;15(8):732-4. [PUBMED: 12160197]

Kumanyika SK, Espeland MA, Bahnson JL, Bottom JB, Charleston JB, Folmar S, et al. Ethnic comparison of weight loss in the Trial of Nonpharmacologic Interventions in the Elderly. Obesity Research 2002;10(2):96-106. [PUBMED: 11836455]

* Whelton PK, Appel LJ, Espeland MA, Applegate WB, Ettinger WH Jr, Kostis JB, et al. Sodium reduction and weight loss in the treatment of hypertension in older persons: a randomized controlled trial of nonpharmacologic interventions in the elderly (TONE). TONE Collaborative Research Group. JAMA 1998;279(11):839-46. [PUBMED: 9515998]

\section{References to studies excluded from this review}

\section{(no authors listed) 1993 \{published data only\}}

Hypertension Prevention Collaborative Research Group. The impact of weight loss on blood pressure. Patient Care 1993;27(17):16.

\section{Abou-Raya 2014 \{published data only\}}

Abou-Raya A, Abou-Raya S, Helmii M. Effect of exercise and dietary weight loss on symptoms and systemic inflammation in obese adults with psoriatic arthritis: Randomized controlled trial. Annals of the Rheumatic Diseases 2014;73(Suppl 2):89-90.

\section{Andersen 1985 \{published data only\}}

Andersen TR, Nielsen PE. Blood pressure lowering effect of weight reduction. Scandinavian Journal of Clinical and Laboratory Investigation. Supplementum 1985;176:7-14. [PUBMED: 3864228]

\section{Andrews 2011 \{published data only\}}

Andrews RC, Cooper AR, Montgomery AA, Norcross AJ, Peters TJ, Sharp DJ, et al. Diet or diet plus physical activity versus usual care in patients with newly diagnosed type 2 diabetes: the Early ACTID randomised controlled trial. The Lancet 2011;378(9786):129-39. [PUBMED: 21705068]

\section{Angelico 2009 \{published data only\}}

Angelico F, Del Ben M, Pacella A, Carnevale R, Loffredo L, Violi F. Low-fat, low-calorie, Mediterranean-style diet improves endothelial dysfunction in patients with the metabolic syndrome. Journal of Diabetes 2009;1(Suppl 1):A43.

\section{Appel 2006 \{published data only\}}

Appel LJ, Sacks FM, Carey VJ, Conlin PR, Erlinger TP, Miller ER III. The effects of macronutrient intake on blood pressure: Subgroup analyses from the OmniHeart randomized feeding study. Journal of Hypertension 2006;24(Suppl 6):177.

\section{Ard 2005 \{published data only\}}

Ard JD, Svetkey LP. Diet and blood pressure: applying the evidence to clinical practice. American Heart Journal 2005;149(5):804-12. [PUBMED: 15894960]

\section{Balas-Nakash 2014 \{published data only\}}

Balas-Nakash M, Munoz-Manrique C, Legorreta-Legorreta J, Rodriguez-Cano A, Mier-Cabrera J, Aguilera-Perez JR. Structured hypocaloric diet is more effective than behavioral therapy in reducing metabolic syndrome in Mexican postmenopausal women: a randomized controlled trial. Menopause 2014;21(7):711-20. [PUBMED: 24378762]

\section{Bao 1999 \{published data only\}}

Bao DQ, Mori TA, Burke V, Puddey IB, Beilin LJ. Dietary fish and weight reduction improves multiple risk factors in overweight, treated hypertensives. [abstract]. Australian \& New Zealand Journal of Medicine 1999;29:148.

\section{Bartels 1974 \{published data only\}}

Bartels RW, Bigalke C, Mollmann H, Schneeberger W, Wessels F. Influence of various hunger-cures on the behavior of body weight and blood pressure as well as on relevant blood parameters [Der Einfluss unterschiedlicher Fastenkuren auf das Gewichts- und Blutdruckverhalten sowie auf relevante metabolische Blutparameter]. Die Medizinische Welt 1974;25(17):725-35. [PUBMED: 4421950]

\section{Bazian 2004 \{published data only\}}

Bazian Ltd. Advice about diet and lifestyle does not reduce blood pressure in people with hypertension. Evidence-Based Healthcare and Public Health 2004;8(6):348-9.

\section{Bouchonville 2014 \{published data only\}}

Bouchonville M, Armamento-Villareal R, Shah K, Napoli N, Sinacore DR, Qualls C, et al. Weight loss, exercise or both and 
cardiometabolic risk factors in obese older adults: results of a randomized controlled trial. International Journal of Obesity 2014;38(3):423-31. [PUBMED: 23823329]

Bouchonville M, Krupa S, Armamento-Villareal R, Sinacore DR, Qualls C, Villareal DT. Weight Loss, Exercise, or Both and Cardiometabolic Risk Factors in Obese Older Adults: Results of a Randomized Controlled Trial. Endocrine Reviews 2012;33(Suppl 3):S18. [DOI: 10.1038/ijo.2013.122]

\section{Cakir 2006 \{published data only\}}

Cakir H, Pinar R. Randomized controlled trial on lifestyle modification in hypertensive patients. Western Journal of Nursing Research 2006;28(2):190-209.

\section{Cambien 1986 \{published data only\}}

Cambien F, Plouin PF, Safar M, Pequignot G, Guillanneuf MT, Dutemple C. Comparative study of a medical and a dietary intervention in overweight hypertensive patients [Essai comparant une intervention medicamenteuse et une intervention dietetique chez des patients ayant une hypertension associee a un surpoids]. Archives des Maladies $d u$ Coeur et des Vaisseaux 1986;79:1002.

Camhi 2010 \{published data only\}

Camhi SM, Stefanick ML, Katzmarzyk PT, Young DR. Metabolic syndrome and changes in body fat from a low-fat diet and/or exercise randomized controlled trial. Obesity 2010;18(3):548-54.

\section{Chen 2009 \{published data only\}}

Chen L, Appel LJ, Loria C, Lin PH, Champagne CM, Elmer PJ, et al. Reduction in consumption of sugar-sweetened beverages is associated with weight loss: the PREMIER trial. The American Journal of Clinical Nutrition 2009;89(5):1299-306. [PUBMED: 19339405]

\section{Childress 2008 \{published data only\}}

Childress S, Brubaker PH, Amico LA, Nesbit BA, Williams CM, Jack Rejeski W. Patterns of physical activity before and after an exercise intervention in overweight/obese older adults with CVD or the metabolic syndrome. Journal of Cardiopulmonary Rehabilitation and Prevention 2008;28(4):268.

\section{Christensen 2013 \{published data only\}}

Christensen P, Frederiksen R, Bliddal H, Riecke BF, Bartels EM, Henriksen $M$, et al. Comparison of three weight maintenance programs on cardiovascular risk, bone and vitamins in sedentary older adults. Obesity 2013;21(10):1982-90. [PUBMED: 23512743]

\section{Coppell 2010 \{published data only\}}

Coppell KJ, Kataoka M, Williams SM, Chisholm AW, Vorgers SM, Mann JI. Nutritional intervention in patients with type 2 diabetes who are hyperglycaemic despite optimised drug treatment - Lifestyle Over and Above Drugs in Diabetes (LOADD) study: randomised controlled trial. BMJ 2010;341:c3337. [PUBMED: 20647285]

\section{Curzio 1989 \{published data only\}}

Curzio JL, Kennedy SS, Elliott HL, Farish E, Barnes JF, Howie CA, et al. Hypercholesterolaemia in treated hypertensives: a controlled trial of intensive dietary advice. Journal of Hypertension. Supplement: Official Journal of the International Society of Hypertension 1989;7(6):S254-5. [PUBMED: 2698935]

\section{Cutler 1997 \{published data only\}}

Cutler JA, Stamler J. Chapter 1. Introduction and summary of the dietary and nutritional methods and findings in the Multiple Risk Factor Intervention Trial. American Journal of Clinical Nutrition 1997;65 (1 Suppl):184S-90S.

De Mello 2008 \{published data only\}

De Mello VDF, Kolehmainen M, Pulkkinen L, Schwab U, Mager U, Laaksonen DE, et al. Downregulation of genes involved in NFB activation in peripheral blood mononuclear cells after weight loss is associated with the improvement of insulin sensitivity in individuals with the metabolic syndrome: The GENOBIN study. Diabetologia 2008;51(11):2060-7.

Diaz 2014 \{published data only\}

Diaz KM, Muntner P, Levitan EB, Brown MD, Babbitt DM, Shimbo $D$. The effects of weight loss and salt reduction on visitto-visit blood pressure variability: results from a multicenter randomized controlled trial. Journal of Hypertension 2014;32(4):840-8. [PUBMED: 24366034]

\section{Ebell 2013 \{published data only\}}

Ebell MH. Intensive lifestyle intervention fails to improve patient-oriented outcomes in persons with obesity and diabetes. American Family Physician 2013;88(12):864A.

\section{Fagerberg 1989 \{published data only\}}

Fagerberg B, Berglund A, Berglund G, Wikstrand J, Andersson OK. Food and health. Weight reduction and decreased sodium chloride intake depress blood pressure but not as much as drugs do [kost och halsa. Viktreduktion och minskat koksaltintag sanker blodtrycket mindre an lakemedel]. Lakartidningen 1989;86(51):4522-4. [PUBMED: 2689815]

Gilliam 2012 \{published data only\}

Gilliam ML. Long-term effects of weight-reducing diets in hypertensive patients. Obstetrics and Gynecology 2012;119(1):180-1.

\section{Gillum 1983 \{published data only\}}

Gillum RF, Prineas RJ, Jeffery RW, Jacobs DR, Elmer PJ, Gomez $\mathrm{O}$, et al. Nonpharmacologic therapy of hypertension: the independent effects of weight reduction and sodium restriction in overweight borderline hypertensive patients. American Heart Journal 1983;105(1):128-33. [PUBMED: 6849226]

Hall 2003 \{published data only\}

Hall WD, Feng Z, George VA, Lewis CE, Oberman A, Huber M, et al. Low-fat diet: effect on anthropometrics, blood pressure, glucose, and insulin in older women. Ethnicity \& Disease 2003;13(3):337-43. [PUBMED: 12894958]

\section{Haynes 1984 \{published data only\}}

Haynes RB, Harper AC, Costley SR, Johnston M, Logan AG, Flanagan PT, et al. Failure of weight reduction to reduce mildly elevated blood pressure: a randomized trial. Journal of Hypertension 1984;2(5):535-9. [PUBMED: 6397541] 
Hayward 2010 \{published data only\}

Hayward CS, Lockwood J, Williams CD, Cole RE, Torres DM, Harrison SA. Lifestyle modification and NAFLD: A prospective, randomized trial. Hepatology 2010;52:622A.

\section{He 2000 \{published data only\}}

He J, Whelton PK, Appel LJ, Charleston J, Klag MJ. Longterm effects of weight loss and dietary sodium reduction on incidence of hypertension. Hypertension 2000;35(2):544-9. [PUBMED: 10679495]

\section{Heshka 2003 \{published data only\}}

Heshka S, Anderson J, Atkinson R, Gadde KM, Nanchahal K. Commercial weight reduction programme reduces weight more than self-help materials. Evidence-Based Healthcare 2003;7(4):179-81.

\section{Heyden 1974 \{published data only\}}

Heyden S, Hames CG. Diet therapy of elevated blood pressure values in overweight persons. Hypertension-intervention study: 1 year's report from the Evans-County (Ga.) study [Diätbehandlung erhöhter Blutdruckwerte bei übergewichtigen Personen. Hypertonie-Interventionsstudie: 1-Jahres-Bericht aus der Evans-County (Ga.)-Studie]. Die Medizinische Welt 1974;25(49):2041-3. [PUBMED: 4444500]

Hsieh 2009 \{published data only\}

Hsieh YC, Hung CT, Lien LM, Bai CH, Chen WH, Yeh CY, et al. A significant decrease in blood pressure through a family-based nutrition health education programme among community residents in Taiwan. Public Health Nutrition 2009;12(4):570-7. [PUBMED: 18561875]

\section{Hyden 1973 \{published data only\}}

Hyden S, Tyroler HA, Hames CG, Bartel A, Thompson JW, Krishan I, et al. Diet treatment of obese hypertensives. Clinical Science and Molecular Medicine. Supplement 1973;45 Suppl 1:209s-12. [PUBMED: 4593567]

\section{Jones 1999 \{published data only\}}

Jones DW, Miller ME, Wofford MR, Anderson DC Jr, Cameron ME, Willoughby DL, et al. The effect of weight loss intervention on antihypertensive medication requirements in the Hypertension Optimal Treatment (HOT) study. American Journal of Hypertension 1999;12(12 Pt 1-2):1175-80. [PUBMED: 10619579]

\section{Karoff 1985 \{published data only\}}

Karoff C, Zidek W, Lange-Asschenfeldt H, Losse H, Vetter H. Blood pressure and intracellular electrolytes during weight reduction. Klinische Wochenschrift 1985;63 Suppl 3:129-31. [PUBMED: 3999629]

\section{Karvetti 1992 \{published data only\}}

Karvetti RL, Hakala P. A seven-year follow-up of a weight reduction programme in Finnish primary health care. European Journal of Clinical Nutrition 1992;46(10):743-52. [PUBMED: 1425528]

\section{Katzel 1995 \{published data only\}}

Katzel LI, Bleecker ER, Colman EG, Rogus EM, Sorkin JD, Goldberg AP. Effects of weight loss vs aerobic exercise training on risk factors for coronary disease in healthy, obese, middleaged and older men. A randomized controlled trial. JAMA 1995;274(24):1915-21. [PUBMED: 8568984]

Kawamura 1993 \{published data only\}

Kawamura M, Akasaka T, Kasatsuki T, Nakajima J, Onodera S, Fujiwara T, et al. Blood pressure is reduced by short-time calorie restriction in overweight hypertensive women with a constant intake of sodium and potassium. Journal of hypertension. Supplement: Official Journal of the International Society of Hypertension 1993;11(5):S320-1. [PUBMED: 8158405]

Kittiskulnam 2014 \{published data only\}

Kittiskulnam P, Kanjanabuch T, Tangmanjitjaroen K, Chancharoenthana W, Praditpornsilpa K, Eiam-Ong S. The beneficial effects of weight reduction in overweight patients with chronic proteinuric immunoglobulin a nephropathy: a randomized controlled trial. Journal of Renal Nutrition 2014;24(3):200-7. [PUBMED: 24759301]

Kolehmainen 2008 \{published data only\}

Kolehmainen M, Salopuro T, Schwab US, Kekalainen J, Kallio P, Laaksonen DE, et al. Weight reduction modulates expression of genes involved in extracellular matrix and cell death: The GENOBIN study. International Journal of Obesity 2008;32(2):292-303.

\section{Korhonen 2003 \{published data only\}}

Korhonen M, Kastarinen M, Uusitupa M, Stevens VJ, Worsley A. Advice from primary care physicians and nurses may improve diet in people with hypertension. Evidence-based Cardiovascular Medicine 2003;7:94-6.

\section{Larson-Meyer 2010 \{published data only\}}

Larson-Meyer DE, Redman L, Heilbronn LK, Martin CK, Ravussin E. Caloric restriction with or without exercise: the fitness versus fatness debate. Medicine and Science in Sports and Exercise 2010;42(1):152-9. [PUBMED: 20010118]

\section{Lindgarde 2001 \{published data only\}}

Lindgarde F. Orlistat with diet was effective and safe for weight loss and coronary risk reduction in obesity. Evidence-Based Medicine 2001;6(2):54.

\section{Mason 2013 \{published data only\}}

Mason C, Foster-Schubert KE, Imayama I, Xiao L, Kong A, Campbell KL, et al. History of weight cycling does not impede future weight loss or metabolic improvements in postmenopausal women. Metabolism: Clinical \& Experimental 2013;62(1):127-36. [PUBMED: 22898251]

\section{Masuo 2012 \{published data only\}}

Masuo K, Rakugi H, Ogihara T, Lambert G. Effects of weight loss on liver function in obese hypertensive patients. Journal of Hypertension 2012;30:e53-4.

Masuo K, Rakugi H, Ogihara T, Lambert GW. Different mechanisms in weight loss-induced blood pressure reduction between a calorie-restricted diet and exercise. Hypertension Research - Clinical \& Experimental 2012;35(1):41-7. [PUBMED: 21814218] 
Masuo K, Rakugi H, Ogihara T, Lambert GW. The effects of weight loss on liver function in obese hypertensive patients. Circulation 2012;125(Suppl 1):P131.

\section{McCarron 2000 \{published data only\}}

McCarron DA, Reusser ME. Cardiovascular risk reduction dietary intervention trial. Drug Benefit Trends 2000;12(5):42-8.

\section{Metz 2000 \{published data only\}}

Metz JA, Stern JS, Kris-Etherton P, Reusser ME, Morris CD, Hatton DC, et al. A randomized trial of improved weight loss with a prepared meal plan in overweight and obese patients: impact on cardiovascular risk reduction. Archives of Internal Medicine 2000;160(14):2150-8. [PUBMED: 10904458]

\section{Noble 1971 \{published data only\}}

Noble RE. A controlled study of a weight reduction regimen. Current Therapeutic Research, Clinical and Experimental 1971;13(11):685-91. [PUBMED: 5000715]

\section{Poppitt 2002 \{published data only\}}

Poppitt SD, Keogh GF, Prentice AM, Williams DE, Sonnemans HM, Valk EE, et al. Long-term effects of ad libitum low-fat, high-carbohydrate diets on body weight and serum lipids in overweight subjects with metabolic syndrome. The American Journal of Clinical Nutrition 2002;75(1):11-20. [PUBMED: 11756055]

\section{Pritchard 2002 \{published data only\}}

Pritchard JE, Nowson CA, Billington T, Wark JD. Benefits of a year-long workplace weight loss program on cardiovascular risk factors. Nutrition and Dietetics 2002;59:87-96.

\section{Reisin 1978 \{published data only\}}

Reisin E, Abel R, Modan M, Silverberg DS, Eliahou HE, Modan B. Effect of weight loss without salt restriction on the reduction of blood pressure in overweight hypertensive patients. The New England Journal of Medicine 1978;298(1):1-6. [PUBMED: 337144]

\section{Rissanen 1985 \{published data only\}}

Rissanen A, Pietinen P, Siljamaki-Ojansuu U, Piirainen H, Reissel P. Treatment of hypertension in obese patients: efficacy and feasibility of weight and salt reduction programs. Acta Medica Scandinavica 1985;218(2):149-56. [PUBMED: 4061119]

\section{Salas-Salvado 2008 \{published data only\}}

Salas-Salvado J, Fernandez-Ballart J, Ros E, MartinezGonzalez MA, Fito M, Estruch R, et al. Effect of a Mediterranean diet supplemented with nuts on metabolic syndrome status: One-year results of the PREDIMED randomized trial. Archives of Internal Medicine 2008;168(22):2449-58.

\section{Salinardi 2012 \{published data only\}}

Salinardi TC, Batra P, Roberts SB, Urban LE, Robinson LM, Pittas AG, et al. A lifestyle intervention reduces body weight and improves cardiometabolic risk factors in worksites. Circulation 2012;126(21 Suppl):A13112.

\section{Samaha 2003 \{published data only\}}

Samaha FF, Iqbal N, Seshadri P, Chicano KL, Daily DA, McGrory J, et al. A low-carbohydrate as compared with a low-fat diet in severe obesity. The New England Journal of Medicine 2003;348(21):2074-81.

\section{Schwab 2008 \{published data only\}}

Schwab U, Seppanen-Laakso T, Yetukuri L, Agren J, Kolehmainen M, Laaksonen DE, et al. Triacylglycerol fatty acid composition in diet-induced weight loss in subjects with abnormal glucose metabolism - The GENOBIN study. PLoS ONE 2008; Vol. 3, issue 7:e2630.

\section{Stamler 1985 \{published data only\}}

Stamler R, Stamler J, Grimm R, Gosch FC, Dyer A. Control of hypertension by regulating nutrition. The 4-year results [Issledovanie po kontroliu gipertonii s pomoshch'iu regulirovaniia pitaniia. Rezul'taty za 4 goda.]. Terapevticheskii Arkhiv 1985;57(11):71-6. [PUBMED: 4082027]

\section{Tate 2011 \{published data only\}}

Tate DF, Turner-McGrievy G, Lyons E, Stevens J, Erickson K, Polzien $\mathrm{K}$, et al. Replacing caloric beverages with water or diet beverages for weight loss in adults: main results of the Choose Healthy Options Consciously Everyday (CHOICE) randomized clinical trial. American Journal of Clinical Nutrition 2012;95(3):555-63. [PUBMED: 22301929]

Tate DF, Turner-McGrievy G, Stevens J, Erickson K, Polzien K, Diamond $\mathrm{M}$, et al. Replacing caloric beverages with water or diet beverages for weight loss in adults: Results of a 6-month randomized controlled trial. Obesity 2011;19(Suppl 1):S68.

\section{Trepanowski 2014 \{published data only\}}

Trepanowski J, Kroeger C, Klempel M, Calvo Y, Varady K. Alternate day fasting versus daily calorie restriction for weight loss and cardio-protection. The FASEB Journal 2014;28(1 Suppl):120.6

\section{Tunyan 2007 \{published data only\}}

Tunyan AM. Cardioprotective effects of antihypertensive therapy with orlistat treatment and hypocaloric diet in combination in obese hypertensive patients. Circulation 2007;115(8):e248.

\section{Tuomilehto 2009 \{published data only\}}

Tuomilehto HPI, Seppa JM, Partinen MM, Peltonen M, Gylling H, Tuomilehto JOI, et al. Lifestyle intervention with weight reduction: First-line treatment in mild obstructive sleep apnea. American Journal of Respiratory and Critical Care Medicine 2009;179(4):320-7.

\section{Vissers 2010 \{published data only\}}

Vissers D, Verrijken A, Mertens I, Van Gils C, Van De Sompel A, Truijen S, et al. Effect of long-term whole body vibration training on visceral adipose tissue: A preliminary report. Obesity Facts 2010;3(2):93-100.

\section{WHO Europ.Coll.Grp. 1974 \{published data only\}}

World Health Organization European Collaborative Group. An international controlled trail in the multifactorial prevention of coronary heart disease. International Journal of Epidemiology 1974;3(3):219-24. [PUBMED: 4606212] 
Yamada 2013 \{published data only\}

Yamada S, Yamada Y, Irie J. A non-calorie-restricted non-ketogenic low-carbohydrate diet is effective as an alternative therapy for patients with type 2 diabetes. Diabetes 2013;62:A192-3.

\section{Additional references}

\section{Anderssen 1995}

Anderssen S, Holme I, Urdal P, Hjermann I. Diet and exercise intervention have favourable effects on blood pressure in mild hypertensives: the Oslo Diet and Exercise Study (ODES). Blood Pressure 1995;4(6):343-9. [PUBMED: 8746601]

\section{Aucott 2005}

Aucott L, Poobalan A, Smith WC, Avenell A, Jung R, Broom J. Effects of weight loss in overweight/obese individuals and longterm hypertension outcomes: a systematic review. Hypertension 2005;45(6):1035-41. [PUBMED: 15897373]

\section{CHEP 2014}

Dasgupta K, Quinn RR, Zarnke KB, Rabi DM, Ravani P, Daskalopoulou SS, et al. The 2014 Canadian Hypertension Education Program recommendations for blood pressure measurement, diagnosis, assessment of risk, prevention, and treatment of hypertension. Canadian Journal of Cardiology 2014;30(5):485-501. [PUBMED: 24786438]

\section{Dickinson 2006}

Dickinson HO, Mason JM, Nicolson DJ, Campbell F, Beyer FR, Cook JV, et al. Lifestyle interventions to reduce raised blood pressure: a systematic review of randomized controlled trials. Journal of Hypertension 2006;24(2):215-33. [PUBMED: 16508562]

\section{ESH-ESC 2013}

Mancia G, Fagard R, Narkiewicz K, Redon J, Zanchetti A, Bohm M, et al. 2013 ESH/ESC Practice Guidelines for the Management of Arterial Hypertension. Blood Pressure 2014;23(1):3-16. [PUBMED: 24359485]

\section{Haynes 2010 [pers comm]}

Haynes B. RE: Cochrane Review [personal communication]. Email to: A Siebenhofer. 10 December 2010.

\section{Higgins 2011}

Higgins JPT, Green S (editors). Cochrane Handbook for Systematic Reviews of Interventions Version 5.1.0 [updated March 2011]. The Cochrane Collaboration, 2011. Available from: www.cochrane-handbook.org.

\section{Horvath 2008}

Horvath K, Jeitler K, Siering U, Stich AK, Skipka G, Gratzer TW, et al. Long-term effects of weight-reducing interventions in hypertensive patients: systematic review and meta-analysis. Archives of Internal Medicine 2008;168(6):571-80. [PUBMED: 18362248]

\section{Howard 2006}

Howard BV, Van Horn L, Hsia J, Manson JE, Stefanick ML, Wassertheil-Smoller S, et al. Low-fat dietary pattern and risk of cardiovascular disease: the Women's Health Initiative Randomized Controlled Dietary Modification Trial. JAMA 2006;295(6):655-66. [PUBMED: 16467234]

\section{IQWiG 2006}

Institute for Quality and Efficiency in Health Care (IQWiG). IQWiG Reports - Commission No. A05-21A: Benefit assessment of non-drug treatment strategies in patients with hypertension: weight reduction [Abschlussbericht A05/21-A: Nutzenbewertung nichtmedikamentöser Behandlungsstrategien bei Patienten mit Bluthochdruck: A-Gewichtsreduktion]. http://iqwig.de/download/ A05-21A_Abschlussbericht_Gewichtsreduktion_bei_Bluthochdruck_neu.pd Köln, Germany, 2006.

\section{JNC 2014}

James PA, Oparil S, Carter BL, Cushman WC, DennisonHimmelfarb C, Handler J, et al. 2014 evidence-based guideline for the management of high blood pressure in adults: report from the panel members appointed to the Eighth Joint National Committee (JNC 8). JAMA 2014;311(5):507-20. [PUBMED: 24352797]

\section{Kenchaiah 2002}

Kenchaiah S, Evans JC, Levy D, Wilson PW, Benjamin EJ, Larson MG, et al. Obesity and the risk of heart failure. The New England Journal of Medicine 2002;347(5):305-13. [PUBMED: 12151467]

\section{Musini 2009}

Musini VM, Wright JM. Factors affecting blood pressure variability: Lessons learned from two systematic reviews of randomized controlled trials. PLOS ONE 22 May 2009;4(5):Article Number: e5673.

\section{NICE 2011}

National Institute for Health and Clinical Excellence (NICE). Hypertension: the clinical management of primary hypertension in adults. 2011. Available from: http:// www.nice.org.uk/nicemedia/live/13561/56007/56007.pdf (accessed 9 April 2015).

\section{PRISMA 2009}

Moher D, Liberati A, Tetzlaff J, Altman DG. Preferred reporting items for systematic reviews and meta-analyses: the PRISMA statement. Annals of Internal Medicine 2009;151(4):264-9. [PUBMED: 19622511]

\section{Review Manager 5 [Computer program]}

The Nordic Cochrane Centre, The Cochrane Collaboration. Review Manager (RevMan). Version Version 5.3.. Copenhagen: The Nordic Cochrane Centre, The Cochrane Collaboration, 2014.

\section{Siebenhofer 2013}

Siebenhofer A, Jeitler K, Horvath K, Berghold A, Siering U, Semlitsch $T$. Long-term effects of weight-reducing drugs in hypertensive patients. Cochrane Database of Systematic Reviews 2013, Issue 3. [DOI: 10.1002/14651858.CD007654.pub3] 


\section{Sjostrom 2004}

Sjostrom L, Lindroos AK, Peltonen M, Torgerson J, Bouchard C, Carlsson B, et al. Lifestyle, diabetes, and cardiovascular risk factors 10 years after bariatric surgery. The New England Journal of Medicine 2004;351(26):2683-93. [PUBMED: 15616203]

\section{Staessen 2005}

Staessen JA, Li Y, Thijs L, Wang JG. Blood pressure reduction and cardiovascular prevention: an update including the 2003-2004 secondary prevention trials. Hypertension research: Official Journal of the Japanese Society of Hypertension 2005;28(5):385-407. [PUBMED: 16156503]

\section{Turnbull 2003}

Turnbull F. Effects of different blood-pressure-lowering regimens on major cardiovascular events: results of prospectively-designed overviews of randomised trials. The Lancet 2003;362(9395):1527-35. [PUBMED: 14615107]

\section{Urdal 1993}

Urdal P, Haaland A, Hjermann I, Gjesdal K, Christian C, Sorensen M, et al. The Oslo Diet and Exercise Study (ODES): Design and objectives. Controlled Clinical Trials 1993;14(3):229-43.

\section{Wannamethee 1996}

Wannamethee SG, Shaper AG. Patterns of alcohol intake and risk of stroke in middle-aged British men. Stroke; a Journal of Cerebral Circulation 1996;27(6):1033-9. [PUBMED: 8650710]

\section{WHO 2005}

World Health Organization. Khatib OMN, El-Guindy MS (editors). Clinical guidelines for the management of hypertension. WHO EMRO Technical Publications Series 29. Available from: http:// www.emro.who.int/dsaf/dsa234.pdf (accessed 6 August 2008).

\section{WHO 2013}

World Health Organization. World Health Day 2013 -

A global brief on hypertension. 2013. Available from:

\section{CHARACTERISTICS OF STUDIES}

Characteristics of included studies [ordered by study ID] http://www.who.int/iris/bitstream/10665/79059/1/ WHO_DCO_WHD_2013.2_eng.pdf (accessed 9 April 2015).

\section{Wilhelm 2014}

Wilhelm SM, Young J, Kale-Pradhan PB. Effect of bariatric surgery on hypertension: a meta-analysis. The Annals of Pharmacotherapy 2014;48(6):674-82. [PUBMED: 24662112]

\section{Wilson 2002}

Wilson PW, D'Agostino RB, Sullivan L, Parise H, Kannel WB. Overweight and obesity as determinants of cardiovascular risk: the Framingham experience. Archives of Internal Medicine 2002;162(16):1867-72. [PUBMED: 12196085]

\section{Woodward 2005}

Woodward M, Lam TH, Barzi F, Patel A, Gu D, Rodgers A, et al. Smoking, quitting, and the risk of cardiovascular disease among women and men in the Asia-Pacific region. International Journal of Epidemiology 2005;34(5):1036-45. [PUBMED: 15914503]

\section{Yusuf 2004}

Yusuf S, Hawken S, Ounpuu S, Dans T, Avezum A, Lanas F, et al. Effect of potentially modifiable risk factors associated with myocardial infarction in 52 countries (the INTERHEART study): case-control study. The Lancet 2004;364(9438):937-52. [PUBMED: 15364185]

\section{References to other published versions of this review Siebenhofer 2011}

Siebenhofer A, Jeitler K, Berghold A, Waltering A, Hemkens LG, Semlitsch T, et al. Long-term effects of weight-reducing diets in hypertensive patients. Cochrane Database of Systematic Reviews 2011, Issue 9. [DOI: 10.1002/14651858.CD008274.pub2]

* Indicates the major publication for the study

\section{Cohen 1991}

Methods

DESIGN: parallel, cluster randomised, no information on blinding

DURATION: 12 months

NUMBER OF STUDY CENTRES: 1

COUNTRY OF PUBLICATION: USA

SPONSOR: -

Participants

WHO PARTICIPATED: hypertensive and obese patients stratified by residents (residents not patients were randomised to intervention or control group)

SETTING: model family practice unit (Pittsburgh)

MAIN INCLUSION CRITERIA:

age 20 to 75 years; $\mathrm{BMI} \geq 28 \mathrm{~kg} / \mathrm{m}^{2}$ (men); $\geq 27 \mathrm{~kg} / \mathrm{m}^{2}$ (women); $\mathrm{SBP} \geq 140 \mathrm{~mm} \mathrm{Hg}$, DBP $\geq 90 \mathrm{~mm} \mathrm{Hg}$ in 2 or more readings

\section{MAIN EXCLUSION CRITERIA:}


Cohen 1991 (Continued)

not described in detail

NUMBER (educationally oriented intervention vs standard consultation): 15 vs 15 patients were randomised ( 10 vs 8 physicians); 15 vs 15 were analysed

GENERAL BASELINE CHARACTERISTICS (dietary intervention vs no dietary intervention): MEAN AGE [YEARS]: 59 vs 60

GENDER [\% MALE]: 27 vs 27

NATIONALITY: -

ETHNICITY: -

WEIGHT [kg]: 92 vs 92

BODY MASS INDEX [kg/m²]: 34 vs 34

SITTING SYSTOLIC BLOOD PRESSURE [mm Hg]: -

SITTING DIASTOLIC BLOOD PRESSURE [mm Hg]: -

MEAN ARTERIAL BLOOD PRESSURE [mm Hg]: 106 vs 106

COMORBID CONDITIONS: obesity

ANTIHYPERTENSIVE TREATMENT: (number of medications 1.6 vs 1.2)

DURATION OF HYPERTENSION: -

SUBGROUP ANALYSES:

weight losers vs weight gainer

Interventions LENGTH OF FOLLOW-UP: 12 months

DIETARY INTERVENTION: physicians ( $\mathrm{n}=10$ ) were taught by a behavioural psychologist; the goal of the dietary advice was to reduce the caloric content of the diet without radically changing the patient's lifestyle; monthly patient consultations and reviewing diet history sheet; the suggested diets were not specifically intended to be salt reducing

NO DIETARY INTERVENTION: physicians $(n=8)$ received no special instructions or materials; the patients continued to be treated with their usual care

Outcomes

\section{PRIMARY OUTCOMES:}

1. MORTALITY: -

2. CARDIOVASCULAR MORBIDITY: -

3. ADVERSE EVENTS: -

\section{SECONDARY OUTCOMES:}

1. CHANGES IN SYSTOLIC BLOOD PRESSURE [mm Hg]: -

2. CHANGES IN DIASTOLIC BLOOD PRESSURE [mm Hg]: -

3. BODY WEIGHT $[\mathrm{kg}]$ :

Definition: body weight change from baseline to 6 months, from baseline to 12 months, and from 6 months to 12 months

ADDITIONAL OUTCOMES MEASURED IN THE STUDY:

1. Mean arterial blood pressure change in $\mathrm{mm} \mathrm{Hg}$

2. Change in number of antihypertensive medications

3. Number of visits

Notes

\section{Risk of bias}

\section{Bias} Authors' judgement Support for judgement

Random sequence genera- Unclear risk tion (selection bias)

\begin{abstract}
Comment: No details on generation sequence are provided Quote: "The residents were stratified by residency year and randomly assigned to either control or experimental groups. ... The experimental or control status of a patient was determined by the status of the physician, and great care was taken to avoid contamination."
\end{abstract}


Cohen 1991 (Continued)

Allocation concealment Unclear risk Comment: Method of concealment is not described
(selection bias)

Blinding (performance

bias and detection bias)

All outcomes

Incomplete outcome data Unclear risk

(attrition bias)

High risk

Comments: No description of randomisation; since the physicians assigned to the experimental group were taught about the weight-reducing programme, knowledge of the allocation intervention was not prevented during study
WITHDRAWALS: none

REASONS/DESCRIPTIONS: -

All outcomes

\begin{tabular}{lll}
$\begin{array}{l}\text { Selective reporting (re- } \\
\text { porting bias) }\end{array}$ & Unclear risk & Comment: No primary and secondary outcomes were defined \\
\hline Other bias & High risk & $\begin{array}{l}\text { Comments: } \\
\text { 1. Lack of information of randomisation }\end{array}$ \\
& $\begin{array}{l}\text { 2. Stratified randomisation of investigators instead of patients with very small } \\
\text { cluster size }\end{array}$
\end{tabular}

\section{Croft 1986}

$\begin{array}{ll}\text { Methods } & \text { DESIGN: parallel, randomised, no information on blinding } \\ \text { DURATION: } 6 \text { months } \\ \text { NUMBER OF STUDY CENTRES: } 1 \\ \text { COUNTRY OF PUBLICATION: UK } \\ \text { SPONSOR: West Midlands Regional Research Committee; UK }\end{array}$

Participants WHO PARTICIPATED: newly diagnosed hypertensive and obese patients
SETTING: outpatient clinic (1 urban group practice)

\section{MAIN INCLUSION CRITERIA:}

age between 35 and 60 years; $\mathrm{BMI}>25 \mathrm{~kg} / \mathrm{m}^{2}$; $\mathrm{SBP}>140 \mathrm{~mm}$ Hg or DBP > $90 \mathrm{~mm} \mathrm{Hg}$, or both, in 3 measurements

\section{MAIN EXCLUSION CRITERIA:}

SBP > 200 mm Hg; DBP > 114 mm Hg; previous antihypertensive medication; myocardial infarction or stroke within the previous 3 months; concurrent serious disease, conditions requiring diets, or medication likely to influence weight or blood pressure

NUMBER: 66 vs 64 were randomised, 66 vs 64 (last observation carried forward analysis)/47 vs 50 were analysed per protocol (dietary intervention vs no dietary intervention)

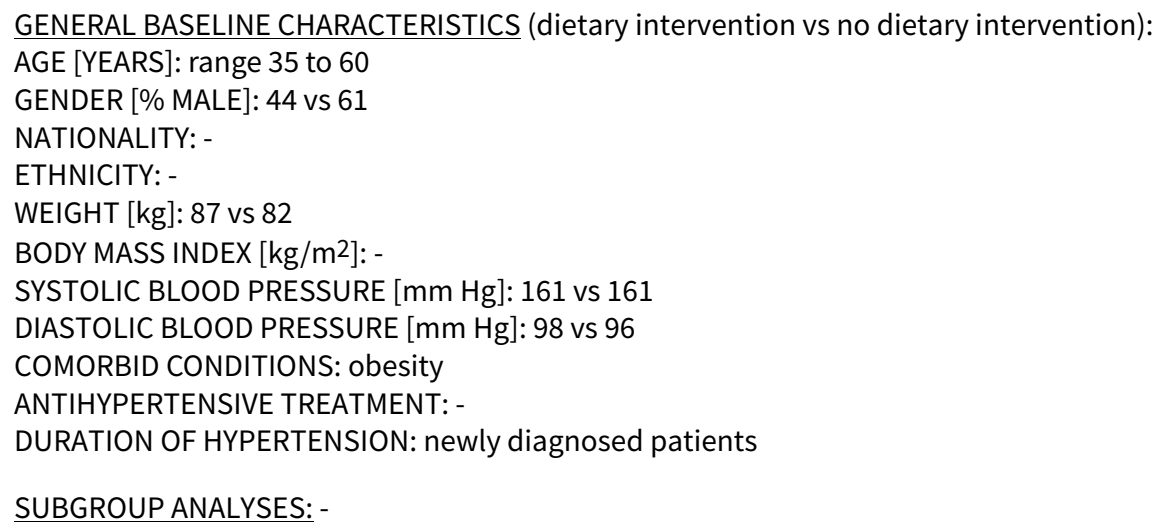


Croft 1986 (Continued)

DIETARY INTERVENTION: active dietary advice for weight reduction by 2 experienced dietitians emphasising the importance of weight reduction for blood pressure control

NO DIETARY INTERVENTION: visits at general practitioners, no active dietary advice; if participants indicated that they intended to lose weight, they were not discouraged but were given no specific advice or diet sheets

ADDITIONAL TREATMENT: advice about modest restriction of salt use and reduction of excessive alcohol intake

$\begin{array}{ll}\text { Outcomes } & \text { PRIMARY OUTCOMES: } \\ \text { 1. MORTALITY: - } & \text { 2. CARDIOVASCULAR MORBIDITY: - } \\ \text { 3. ADVERSE EVENTS: - } & \\ \text { SECONDARY OUTCOMES: } & \text { 1. CHANGES IN SYSTOLIC BLOOD PRESSURE [mm Hg]: } \\ \text { Definition: SBP change from baseline to endpoint visit } \\ \text { 2. CHANGES IN DIASTOLIC BLOOD PRESSURE [mm Hg]: } \\ \text { Definition: DBP change from baseline to endpoint visit } \\ \text { 3. BODY WEIGHT [kg]: } \\ \text { Definition: body weight change from baseline to endpoint visit } \\ \text { ADDITIONAL OUTCOMES MEASURED IN THE STUDY: } \\ \text { 1. Start of antihypertensive medication }\end{array}$

\section{Notes}

\section{Risk of bias}

\begin{tabular}{|c|c|c|}
\hline Bias & Authors' judgement & Support for judgement \\
\hline $\begin{array}{l}\text { Random sequence genera- } \\
\text { tion (selection bias) }\end{array}$ & Unclear risk & Comment: No details on generation sequence are provided \\
\hline $\begin{array}{l}\text { Allocation concealment } \\
\text { (selection bias) }\end{array}$ & Unclear risk & Comment: Method of concealment is not described \\
\hline $\begin{array}{l}\text { Blinding (performance } \\
\text { bias and detection bias) } \\
\text { All outcomes }\end{array}$ & Unclear risk & $\begin{array}{l}\text { Quote: "... (using random number tables) ..." } \\
\text { Comment: as described for normotensive participants only; no information on } \\
\text { blinding }\end{array}$ \\
\hline $\begin{array}{l}\text { Incomplete outcome data } \\
\text { (attrition bias) } \\
\text { All outcomes }\end{array}$ & Low risk & $\begin{array}{l}\text { Quote: "... The data was submitted to an 'intention to treat' analysis which in- } \\
\text { cluded all entrants and assumed that no further change in weight or blood } \\
\text { pressure occurred for drop-outs after the last occasion on which they attend- } \\
\text { ed." } \\
\text { In addition an "outcome of continued attendance" analysis was used, which } \\
\text { compared only those participants still attending after } 6 \text { months } \\
\text { WITHDRAWALS (dietary intervention vs no dietary intervention): } 17 \text { vs } 3 \\
\text { REASONS/DESCRIPTIONS (dietary intervention vs no dietary intervention): - }\end{array}$ \\
\hline $\begin{array}{l}\text { Selective reporting (re- } \\
\text { porting bias) }\end{array}$ & Unclear risk & Comment: No primary and secondary outcomes were defined \\
\hline Other bias & High risk & $\begin{array}{l}\text { Comments: } \\
\text { 1. Lack of information on randomisation and concealment of allocation in- } \\
\text { creases risk of bias even using the LOCF analysis } \\
\text { 2. There was no information on reasons for and description of dropouts }\end{array}$ \\
\hline
\end{tabular}




DESIGN: parallel, randomised, open
DURATION: 13 months (56 weeks)
NUMBER OF STUDY CENTRES: 4
COUNTRY OF PUBLICATION: USA
SPONSOR: grant from National Heart, Lung and Blood Institute; drugs were supplied by the following
companies: Ayerst Laboratories, New York; Merck Sharp \& Dohme, West Point, PA; Ciba-Geigy Corp,
Summit, NJ; Boehringer Ingelheim Ltd., Ridgefield, CT; USV Pharmaceutical Corp, Tuckahoe, NY; G.D.
Searle \& Co, Chicago

Participants

WHO PARTICIPATED: people who were previously enrolled in the HDFP treated with antihypertensive drugs and who had sufficiently controlled hypertension. The dietary change on the return of hypertension after withdrawal of prolonged antihypertensive therapy (DISH) included 7 treatment arms; the results of 2 of those arms met the inclusion criteria for this review (hypertensive and obese patients with either dietary intervention or not)

SETTING: outpatient clinic

MAIN INCLUSION CRITERIA:

HDFP participants; DBP $\geq 95 \mathrm{~mm} \mathrm{Hg}$ on first screening, confirmed by second screening with DBP $\geq 90$ $\mathrm{mm} \mathrm{Hg}$; patients had received antihypertensive medication for at least 5 years; eligible participants had to be "controlled"; hypertensive persons defined by:

1. no $\mathrm{SBP}>180 \mathrm{~mm} \mathrm{Hg}$ during previous year

2. average $\mathrm{DBP}<95 \mathrm{~mm} \mathrm{Hg}$ during previous year

3. average of last $2 \mathrm{DBP} \leq 90 \mathrm{~mm} \mathrm{Hg}$ and neither $>95 \mathrm{~mm} \mathrm{Hg}$

MAIN EXCLUSION CRITERIA:

history of congestive heart failure; myocardial infarction; stroke or transient ischaemic attacks; creatinine level $\geq 2.5 \mathrm{mg} / \mathrm{dl}$; ß-blocker therapy for angina; glucocorticoid therapy for indefinite period

NUMBER (dietary intervention vs no dietary intervention): 87 vs 89 participants were randomised

GENERAL BASELINE CHARACTERISTICS (dietary intervention vs no dietary intervention):

MEAN AGE [YEARS]: 56 vs 57

GENDER [\% MALE]: 32 vs 36

NATIONALITY: USA

ETHNICITY: black: $62 \%$ to $70 \%$, no further information

WEIGHT [kg]: 86 vs 90

BODY MASS INDEX $\left[\mathrm{kg} / \mathrm{m}^{2}\right]$ : -

SYSTOLIC BLOOD PRESSURE [mm Hg]: 127.6 vs 127.6

DIASTOLIC BLOOD PRESSURE [mm Hg]: 80.9 vs 79.6

COMORBID CONDITIONS: obesity

ANTIHYPERTENSIVE TREATMENT [\%]: 100 vs 100

DURATION OF HYPERTENSION: at least 5 years in both groups

SUBGROUP ANALYSES:

results from participants with mild and severe hypertension (not clear whether subgroups were predefined or post-hoc)

DIETARY INTERVENTION: according to revised "Metropolitan Life Insurance" standards; intervention consisted of 8 initial weekly group sessions followed by monthly sessions plus individual consultation as needed NO DIETARY INTERVENTION: no recommendations

ADDITIONAL TREATMENT: discontinuation of antihypertensive treatment using a step-down withdrawal program; biweekly consultations for BP measurement for 16 weeks followed by monthly consultations; no change in salt uptake 
DISH 1985 (Continued)
Outcomes
PRIMARY OUTCOMES:
1. MORTALITY: -
2. CARDIOVASCULAR MORBIDITY: -
3. ADVERSE EVENTS:
Definition: withdrawal due to the need to restart antihypertensive medication
SECONDARY OUTCOMES:
1. CHANGES IN SYSTOLIC BLOOD PRESSURE [mm Hg]: -
2. CHANGES IN DIASTOLIC BLOOD PRESSURE [mm Hg]: -
3. BODY WEIGHT [kg]:
Definition: body weight change from baseline to endpoint visit
ADDITIONAL OUTCOMES MEASURED IN THE STUDY:
1. Number of participants without antihypertensive medication
2. Change in sodium excretion

\section{Notes}

\section{Risk of bias}

\begin{tabular}{lll}
\hline Bias & Authors' judgement & Support for judgement \\
\hline $\begin{array}{l}\text { Random sequence genera- } \\
\text { tion (selection bias) }\end{array}$ & Unclear risk & Comment: No details on generation sequence are provided \\
\hline $\begin{array}{l}\text { Allocation concealment } \\
\text { (selection bias) }\end{array}$ & Unclear risk & Comment: Method of concealment is not described \\
\hline $\begin{array}{l}\text { Blinding (performance } \\
\text { bias and detection bias) }\end{array}$ & High risk & Comment: Open design, no blinding described \\
All outcomes & High risk & \\
\hline $\begin{array}{l}\text { Incomplete outcome data } \\
\text { (attrition bias) }\end{array}$ & & $\begin{array}{l}\text { WITHDRAWALS (dietary intervention vs no dietary intervention): } \\
\text { All outcomes }\end{array}$ \\
& $\begin{array}{l}\text { 0 vs 0 concerning the endpoint success of withdrawal from antihypertensive } \\
\text { medication; } \\
20 \text { vs 12 concerning body weight at week 56; } \\
\text { although there were no losses to follow-up in the relevant subgroups concern- } \\
\text { ing success of discontinuing antihypertensive treatment, for 13\% respectively } \\
23 \% \text { participants weight at week 56 is not reported } \\
\text { REASONS/DESCRIPTIONS: No reasons for incomplete data are mentioned }\end{array}$ \\
\hline
\end{tabular}

Selective reporting (re- Unclear risk Comment: No primary and secondary outcomes were defined
porting bias)

$\begin{array}{ll}\text { Other bias } & \text { Comment: } \\ & \text { 1. Randomisation before consent of participants (possible selection bias) } \\ \text { 2. Different body weight at baseline } & \text { 3. Participants participated in previous trial for } 5 \text { years (selected population } \\ \text { may not be representative) }\end{array}$

\section{Jalkanen 1991}

Methods

DESIGN: parallel, randomised, no information on blinding

DURATION: 12 months

NUMBER OF STUDY CENTRES: 2

COUNTRY OF PUBLICATION: - 
Jalkanen 1991 (Continued)

SPONSOR: -

Participants

WHO PARTICIPATED: overweight hypertensive patients (selected from files)

SETTING: outpatient clinic (2 hypertension clinics in Finland)

MAIN INCLUSION CRITERIA:

age 35 to 59 years; BMI 27 to $34 \mathrm{~kg} / \mathrm{m}^{2}$; DBP $\geq 95 \mathrm{~mm} \mathrm{Hg}$

MAIN EXCLUSION CRITERIA: -

NUMBER: 25 vs 25 were randomised; 24 vs 25 were analysed (dietary intervention vs no dietary intervention)

GENERAL BASELINE CHARACTERISTICS (dietary intervention vs no dietary intervention):

MEAN AGE [YEARS]: 49

GENDER [\% MALE]: - (" ... as many men as women ... ")

NATIONALITY: -

ETHNICITY: -

WEIGHT [kg]: 86 vs 80

BODY MASS INDEX $\left[\mathrm{kg} / \mathrm{m}^{2}\right]:-$

SYSTOLIC BLOOD PRESSURE [mm Hg]: 152 vs 155

DIASTOLIC BLOOD PRESSURE [mm Hg]: 101 vs 102

COMORBID CONDITIONS: -

ANTIHYPERTENSIVE TREATMENT: - (25 of 50 enrolled participants antihypertensive treatment with di-

uretics or ß-blocker)

DURATION OF HYPERTENSION: -

SUBGROUP ANALYSES: -

Interventions

LENGTH OF FOLLOW-UP: 12 months

DIETARY INTERVENTION: individually planned energy-restricted diet of 1000 to 1500 kcal per day, weekly (after 6 months every 3 weeks); sessions including discussions and lessons on behavioural modification, choice of food, physical exercise, and medical aspects of overweight and weight reduction; 1.5 hour duration; total number of lectures about 40 hours; the participants received leaflets on the reduction of salt and fat consumption and on the increase of physical activity; lectures by different medical experts; nutritionists interview; laboratory tests

NO DIETARY INTERVENTION: visits every 3 months; no personal counselling; nutritionists interview; laboratory tests

ADDITIONAL TREATMENT: participants' doctors were asked to keep the dosage of antihypertensive drugs at the initial level

Outcomes

PRIMARY OUTCOMES:

1. MORTALITY: -

2. CARDIOVASCULAR MORBIDITY:-

3. ADVERSE EVENTS: -

SECONDARY OUTCOMES:

1. CHANGES IN SYSTOLIC BLOOD PRESSURE [mm Hg]:

Definition: SBP change from baseline to endpoint visit

2. CHANGES IN DIASTOLIC BLOOD PRESSURE [mm Hg]:

Definition: DBP change from baseline to endpoint visit

3. BODY WEIGHT [kg]:

Definition: body weight change from baseline to endpoint visit

ADDITIONAL OUTCOMES MEASURED IN THE STUDY:

1. Change in lipid parameters

2. Change in potassium and sodium excretions

3. Change in dietary factors (fats and protein) 
Jalkanen 1991 (Continued)

Notes

\section{Risk of bias}

\begin{tabular}{|c|c|c|}
\hline Bias & Authors' judgement & Support for judgement \\
\hline $\begin{array}{l}\text { Random sequence genera- } \\
\text { tion (selection bias) }\end{array}$ & Unclear risk & Comment: No details on generation sequence are provided \\
\hline $\begin{array}{l}\text { Allocation concealment } \\
\text { (selection bias) }\end{array}$ & Unclear risk & Comment: Method of concealment is not described \\
\hline $\begin{array}{l}\text { Blinding (performance } \\
\text { bias and detection bias) } \\
\text { All outcomes }\end{array}$ & Unclear risk & $\begin{array}{l}\text { Comments: No description of randomisation; no information on blinding for } \\
\text { investigators }\end{array}$ \\
\hline $\begin{array}{l}\text { Incomplete outcome data } \\
\text { (attrition bias) } \\
\text { All outcomes }\end{array}$ & High risk & $\begin{array}{l}\text { WITHDRAWALS (dietary intervention vs no dietary intervention): } 1 \text { vs } 0 \\
\text { REASONS/DESCRIPTIONS: - }\end{array}$ \\
\hline $\begin{array}{l}\text { Selective reporting (re- } \\
\text { porting bias) }\end{array}$ & Unclear risk & Comment: No primary and secondary outcomes were defined \\
\hline Other bias & High risk & $\begin{array}{l}\text { Comments: } \\
\text { 1. Lack of information on randomisation and concealment of allocation and } \\
\text { blinding increases risk of bias } \\
\text { 2. No information provided on the reason for and description of the dropout in } \\
\text { the intervention group } \\
\text { 3. The effect of weight reduction is not clearly identified; advice about behav- } \\
\text { ioural modification, physical exercise, and salt reduction were also part of the } \\
\text { intervention }\end{array}$ \\
\hline
\end{tabular}

\section{ODES 1995}

DESIGN: parallel, $2 \times 2$ factorial, randomised, open design
DURATION: 12 months
NUMBER OF STUDY CENTRES: unclear (probably 1, because all eligible participants were screened at
the Ullevaal Hospital, Oslo)
COUNTRY OF PUBLICATION: Norway
SPONSOR: supported by grant from the Research Council of Norway, the Norwegian Council of Cardio-
vascular Diseases, and the insurance company Vital Friskvern

Participants

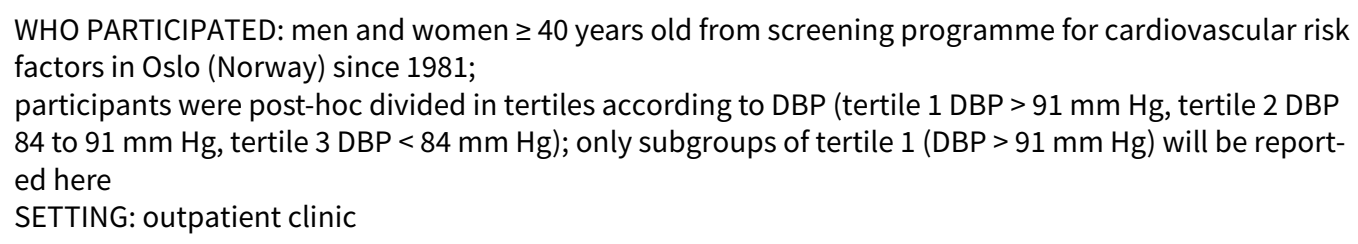

\section{MAIN EXCLUSION CRITERIA:}


overt cardiovascular disease, diabetes, treatment with antihypertensive drugs or acetylsalicylic acid, lipid-lowering diet

No exercise subgroup (dietary intervention vs no dietary intervention)

NUMBER: 55 vs 43 participants were randomised, 16 vs 12 participants with complete data were posthoc allocated to tertile 1 and analysed

GENERAL BASELINE CHARACTERISTICS TERTILE 1 (dietary intervention vs no dietary intervention):

MEAN AGE [YEARS]: -

GENDER [\% MALE]: -

NATIONALITY: Norwegian

ETHNICITY: -

WEIGHT [kg]: -

BODY MASS INDEX [kg/m²]: 30 vs 30

SITTING SYSTOLIC BLOOD PRESSURE [mm Hg]: 145 vs 138

SITTING DIASTOLIC BLOOD PRESSURE [mm Hg]: 97 vs 96

COMORBID CONDITIONS: -

ANTIHYPERTENSIVE TREATMENT: 0 vs 0 (exclusion criteria)

DURATION OF HYPERTENSION: -

Exercise subgroup (exercise + dietary intervention vs exercise + no dietary intervention)

NUMBER: 67 vs 54 participants were randomised, 24 vs 20 participants with complete data were posthoc allocated to tertile 1 and analysed

GENERAL BASELINE CHARACTERISTICS TERTILE 1 (exercise + dietary intervention vs exercise + no dietary intervention):

MEAN AGE [YEARS]: -

GENDER [\% MALE]: -

NATIONALITY: Norwegian

ETHNICITY: -

WEIGHT [kg]: -

BODY MASS INDEX [kg/m²]: 30 vs 30

SITTING SYSTOLIC BLOOD PRESSURE [mm Hg]: 143 vs 140

SITTING DIASTOLIC BLOOD PRESSURE [mm Hg]: 97 vs 96

COMORBID CONDITIONS: -

ANTIHYPERTENSIVE TREATMENT: 0 vs 0 (exclusion criteria)

DURATION OF HYPERTENSION: -

SUBGROUP ANALYSES: -

Interventions

LENGTH OF FOLLOW-UP: 12 months

\section{No exercise subgroup:}

DIETARY INTERVENTION: individual dietary counselling for each participant together with participant's spouse; main emphasis was a low-calorie diet and a substantial increase in the intake of fish and fish products, an increase in the consumption of vegetables and fibre-rich products of complex carbohydrates, and a reduction in intake of sugar and saturated fat; target body weight reduction was agreed upon, usually 0.5 to $1 \mathrm{~kg}$ monthly according to Anderssen 1995 and 0.5 to $2 \mathrm{~kg}$ according to the design paper Urdal 1993; hypertensive participants were also advised to reduce salt intake

Follow-up of dietary habits took place at months 3 and 9

NO DIETARY INTERVENTION: no dietary counselling, no change in lifestyle

\section{Exercise subgroup:}

DIETARY INTERVENTION + EXERCISE: individual counselling as mentioned above as well as additional supervised aerobic exercise program consisting of circuit training and jogging for 1 hour 3 times a week NO DIETARY INTERVENTION + EXERCISE: no dietary counselling but same exercise program as mentioned above 
ODES 1995 (Continued)

ADDITIONAL TREATMENT: all participants were advised against smoking

$\begin{array}{ll}\text { Outcomes } & \text { PRIMARY OUTCOMES: } \\ \text { 1. MORTALITY: - } \\ \text { 2. CARDIOVASCULAR MORBIDITY: - } \\ \text { 3. ADVERSE EVENTS: - } \\ \text { SECONDARY OUTCOMES: } \\ \text { 1. CHANGES IN SYSTOLIC BLOOD PRESSURE [mm Hg]: } \\ \text { Definition: SBP change from baseline to endpoint visit } \\ \text { 2. CHANGES IN DIASTOLIC BLOOD PRESSURE [mm Hg]: } \\ \text { Definition: DBP change from baseline to endpoint visit } \\ \text { 3. BODY WEIGHT [kg]: } \\ \text { Definition: changes in BMI from baseline to endpoint visit }\end{array}$

ADDITIONAL OUTCOMES MEASURED IN THE STUDY:

1. Effect on haemostatic variables (primary study endpoint)

Notes

Risk of bias

\begin{tabular}{lll}
\hline Bias & Authors' judgement & Support for judgement \\
\hline $\begin{array}{l}\text { Random sequence genera- } \\
\text { tion (selection bias) }\end{array}$ & Unclear risk & $\begin{array}{l}\text { Quote: "Each participant has a 25\% chance of being allocated to each of the } \\
\text { four treatment groups. The list is not blocked in any way, but randomization is } \\
\text { stratified by sex." }\end{array}$ \\
\hline $\begin{array}{l}\text { Allocation concealment } \\
\text { (selection bias) }\end{array}$ & Unclear risk & $\begin{array}{l}\text { Quote: "A sealed envelope is opened, revealing the randomization number and } \\
\text { the name of the group to which the participant has been allocated." No infor- } \\
\text { mation about numbered or opaque envelopes }\end{array}$ \\
\hline
\end{tabular}

Blinding (performance

High risk

Quote: "Unmasked, but blinded objective blood analyses"

bias and detection bias)

All outcomes

Incomplete outcome data High risk

(attrition bias)

All outcomes
Not reported for the hypertensive subgroup (tertile 1)

WITHDRAWALS (only for the whole study population of normo- and hypertensives):

No exercise subgroup (dietary intervention vs no dietary intervention): 3 vs 0

Exercise subgroup (dietary intervention vs no dietary intervention): 2 vs 5

REASONS/DESCRIPTIONS:

10 total dropouts in 3 groups (diet, exercise, and combined)

- refused to participate: 5

- injury due to trial-associated exercise: 1

- carcinoma: 2

- exercise-unrelated herniated vertebral disk: 1

- cardiac event: 1
Comment: Post-hoc analyses of blood pressure; not all predefined outcomes are reported for each tertile (e.g. quality of life)
Selective reporting (reporting bias)
High risk

High risk
Comment: 
1. Final analysis NOT done according to the intention-to-treat-principle, also it was initially planned

2. Multiple testing was done without adjustment (e.g. Bonferroni correction)

3. Hypertensive participants in dietary-intervention group advised to reduce salt intake (intervention bias)

4. Tertile 3 was defined as DBP $<84 \mathrm{~mm} \mathrm{Hg}$, whereas inclusion criteria was $\mathrm{DBP}>86 \mathrm{~mm} \mathrm{Hg}$. In total, 68 participants (31\%) were analysed in tertile 3 !

ODES 1995 no exercise

Methods See ODES 1995

\section{Participants}

Interventions

Outcomes

Notes

\section{ODES 1995 with exercise}

\begin{tabular}{ll}
\hline Methods see ODES 1995 \\
\hline Participants \\
\hline Interventions \\
\hline Outcomes \\
\hline Notes
\end{tabular}

\section{Ruvolo 1994}

\begin{tabular}{ll}
\hline Methods & DESIGN: parallel, randomised, no information on blinding \\
DURATION: 6 months \\
NUMBER OF STUDY CENTRES: 1 \\
COUNTRY OF PUBLICATION: Italy \\
SPONSOR: - \\
WHO PARTICIPATED: overweight hypertensive patients on 10 mg amlodipine daily \\
SETTING: outpatient clinic \\
MAIN INCLUSION CRITERIA: \\
BMI > 30 kg/m², DBP > 100 mm Hg \\
MAIN EXCLUSION CRITERIA: \\
heart failure, COrOnary artery disease, diabetes mellitus \\
NUMBER: 16 vs 16 were randomised, 16 vs 16 were analysed (dietary intervention vs no dietary inter- \\
vention) \\
GENERAL BASELINE CHARACTERISTICS (dietary intervention vs no dietary intervention):
\end{tabular}


Ruvolo 1994 (Continued)

MEAN AGE [YEARS]: 53

GENDER [\% MALE]: 53

NATIONALITY: Italian

ETHNICITY: -

WEIGHT [kg]: 98 vs 97

BODY MASS INDEX [kg/m²]: 34 vs 34

SYSTOLIC BLOOD PRESSURE [mm Hg]: 178 vs 176

DIASTOLIC BLOOD PRESSURE [mm Hg]: 107 vs 106

COMORBID CONDITIONS: -

ANTIHYPERTENSIVE TREATMENT [\%]: 100 with amlodipine $10 \mathrm{mg}$

DURATION OF HYPERTENSION: -

SUBGROUP ANALYSES: -

Interventions

LENGTH OF FOLLOW-UP: 6 months

DIETARY INTERVENTION: weight-reducing diet, no restriction on salt uptake

NO DIETARY INTERVENTION: no counselling

ADDITIONAL TREATMENT: amlodipine $10 \mathrm{mg}$

\begin{tabular}{ll}
\hline Outcomes & PRIMARY OUTCOMES: \\
1. MORTALITY: - \\
2. CARDIOVASCULAR MORBIDITY: - \\
3. ADVERSE EVENTS: reported \\
SECONDARY OUTCOMES: \\
1. CHANGES IN SYSTOLIC BLOOD PRESSURE [mm Hg]: \\
Definition:SBP change from baseline to endpoint visit \\
2. CHANGES IN DIASTOLIC BLOOD PRESSURE [mm Hg]: \\
Definition: DBP change from baseline to endpoint visit \\
3. BODY WEIGHT [kg]: \\
Definition: body weight change from baseline to endpoint visit \\
ADDITIONAL OUTCOMES MEASURED IN THE STUDY: \\
1. Change in left ventricular dimensions \\
2. Change in heart rate
\end{tabular}

Notes

Risk of bias

\begin{tabular}{lll}
\hline Bias & Authors' judgement & Support for judgement \\
\hline $\begin{array}{l}\text { Random sequence genera- } \\
\text { tion (selection bias) }\end{array}$ & Unclear risk & Comment: No details on sequence generation are provided \\
\hline $\begin{array}{l}\text { Allocation concealment } \\
\text { (selection bias) }\end{array}$ & Unclear risk & Comment: Method of concealment is not described \\
\hline $\begin{array}{l}\text { Blinding (performance } \\
\text { bias and detection bias) }\end{array}$ & Unclear risk & $\begin{array}{l}\text { Comments: No description of randomisation; no information on blinding for } \\
\text { ill outcomestigators }\end{array}$ \\
\hline $\begin{array}{l}\text { Incomplete outcome data } \\
\text { (attrition bias) }\end{array}$ & High risk & $\begin{array}{l}\text { WITHDRAWALS (dietary intervention vs no dietary intervention): 2 vs 0 } \\
\text { All outcomes }\end{array}$ \\
\hline $\begin{array}{l}\text { Selective reporting (re- } \\
\text { porting bias) }\end{array}$ & Unclear risk & Comment: No primary and secondary outcomes were defined \\
\hline \hline
\end{tabular}

Long-term effects of weight-reducing diets in people with hypertension (Review) 
Ruvolo 1994 (Continued)

Other bias High risk

Comments:

1. Lack of information on randomisation and concealment of allocation and blinding increases risk of bias

2. No information provided on the reason for and description of the dropout in the intervention group

TAIM 1992

\begin{tabular}{ll}
\hline Methods & DESIGN: $3 \times 3$ factorial, randomised, open design \\
& DURATION: 6 months (phase I) \\
& NUMBER OF STUDY CENTRES: 3 \\
COUNTRY OF PUBLICATION: USA \\
SPONSOR: National Heart, Lung and Blood Institute
\end{tabular}

Participants
WHO PARTICIPATED: obese hypertensive patients

The trial consisted of 2 phases. Phase I was performed in a $3^{\star} 3$ factorial design with follow-up of 6 months. Phase II was performed in a $2 * 2$ factorial design (usual care vs weight-reducing diet). Since drop-out in usual-care group was $29 \%$ to $36 \%$ for phase II, only phase I will be analysed SETTING: outpatient clinic at 3 university hospitals (Bronx (New York), Birmingham (Alabama), Jackson (Mississippi))

MAIN INCLUSION CRITERIA:

age 21 to 65 years; $110 \%$ to $116 \%$ of ideal body weight; sitting DBP (preliminary screened: treated $\leq 100$ $\mathrm{mm} \mathrm{Hg}$, untreated 90 to $104 \mathrm{~mm} \mathrm{Hg}$; first clinic visit: 90 to $100 \mathrm{~mm} \mathrm{Hg}$; second clinic visit: < $115 \mathrm{~mm} \mathrm{Hg}$ ); no antihypertensive medication or discontinuation of current medication for at least 2 weeks before baseline BP measurement

\section{MAIN EXCLUSION CRITERIA:}

myocardial infarction within 1 year before study entry; medical history of stroke, bronchial asthma, insulin-dependent diabetes mellitus, or allergy to thiazides or ß-blockers; other major diseases (e.g. kidney disease, liver disease, or cancer); baseline creatinine $\geq 2 \mathrm{mg} / \mathrm{dl}$; pregnancy; scheduled surgery

NUMBER: 878 participants randomised

Placebo groups (weight loss vs usual diet)

NUMBER: 100 vs 100 randomised, 89 vs 90 analysed

GENERAL BASELINE CHARACTERISTICS:

MEAN AGE [YEARS]: 49 vs 47

GENDER [\% MALE]: 59 vs 41

NATIONALITY: USA

ETHNICITY: white: $67 \%$ vs $65 \%$; black: $33 \%$ vs $35 \%$

WEIGHT [kg]: 90 vs 86 (199 lbs. vs 190 lbs.)

BODY MASS INDEX [kg/m²]: - (\% ideal weight 138 vs 136)

SITTING SYSTOLIC BLOOD PRESSURE [mm Hg]: 142 vs 144

SITTING DIASTOLIC BLOOD PRESSURE [mm Hg]: 93 vs 93

COMORBID CONDITIONS: smokers: $14 \%$ vs $15 \%$, alcohol use ( $\geq 1$ drink/week): $35 \%$ vs $37 \%$

ANTIHYPERTENSIVE TREATMENT: $63 \%$ vs $65 \%$

DURATION OF HYPERTENSION: -

SUBGROUP ANALYSES: -

Chlorthalidone groups (weight loss vs usual diet)

NUMBER: 95 vs 97 randomised, 86 vs 87 analysed

GENERAL BASELINE CHARACTERISTICS:

MEAN AGE [YEARS]: 47 vs 49

GENDER [\% MALE]: 50 vs 60 
TAIM 1992 (Continued)

NATIONALITY: USA

ETHNICITY: white: $67 \%$ vs $67 \%$; black: $33 \%$ vs $33 \%$

WEIGHT [kg]: 87 vs 89 (192 lbs. vs 197 lbs.)

BODY MASS INDEX [kg/m²]: - (\% ideal weight 138 vs 137 )

SITTING SYSTOLIC BLOOD PRESSURE [mm Hg]: 138 vs 142

SITTING DIASTOLIC BLOOD PRESSURE [mm Hg]: 92 vs 92

COMORBID CONDITIONS: smokers: $18 \%$ vs $13 \%$, alcohol use ( $\geq 1$ drink/week): $39 \%$ vs $42 \%$

ANTIHYPERTENSIVE TREATMENT: $61 \%$ vs $70 \%$

DURATION OF HYPERTENSION: -

SUBGROUP ANALYSES: -

Atenolol groups (weight loss vs usual diet)

NUMBER: 96 vs 99 randomised, 88 vs 87 analysed

GENERAL BASELINE CHARACTERISTICS:

MEAN AGE [YEARS]: 48 vS 48

GENDER [\% MALE]: 52 vs 64

NATIONALITY: USA

ETHNICITY: white: $67 \%$ vs $67 \%$; black: $33 \%$ vs $33 \%$

WEIGHT [kg]: 88 vs 89 (193 lbs. vs 195 lbs.)

BODY MASS INDEX [kg/m²]: - (\% ideal weight 136 vs 136)

SITTING SYSTOLIC BLOOD PRESSURE [mm Hg]: 144 vs 141

SITTING DIASTOLIC BLOOD PRESSURE [mm Hg]: 94 vs 93

COMORBID CONDITIONS: smokers: $14 \%$ vs $20 \%$, alcohol use ( $\geq 1$ drink/week): $37 \%$ vs $44 \%$

ANTIHYPERTENSIVE TREATMENT: $66 \%$ vs $63 \%$

DURATION OF HYPERTENSION: -

SUBGROUP ANALYSES: -

Interventions LENGTH OF FOLLOW-UP: 6 months (phase I)

DIETARY INTERVENTION: weight-reducing diet (standard program of diet counselling and nutrition education with the goal of a reduction of $10 \%$ of baseline weight or $4.54 \mathrm{~kg}$, whichever was greater); 10 weekly group sessions within the first 6 months, subsequently individual or group counselling sessions with a nutritionist at least every 6 weeks, after 12 months dietary counselling on a quarterly basis NO DIETARY INTERVENTION: no diet and nutritional counselling or education

ADDITIONAL TREATMENT: pharmacological antihypertensive treatment according to subgroup allocation (placebo or diuretic or ß-blocker); medication was stepped up if BP reached predefined escape levels; regular monthly clinic visits for the first 6 months, every 3 months thereafter

PRIMARY OUTCOMES:
1. MORTALITY: -
2. CARDIOVASCULAR MORBIDITY: -
3. ADVERSE EVENTS: -
SECONDARY OUTCOMES:
1. CHANGES IN SYSTOLIC BLOOD PRESSURE [mm Hg]:
Definition: SBP change from baseline to endpoint visit
2. CHANGES IN DIASTOLIC BLOOD PRESSURE [mm Hg]:
Definition: DBP change from baseline to endpoint visit
3. BODY WEIGHT [kg]:
Definition: body weight change from baseline to endpoint visit
ADDITIONAL OUTCOMES MEASURED IN THE STUDY:
1. Change in sodium excretion
2. Change in potassium excretion
3. Quality of life (life satisfaction scale)
4. Symptoms and mental function (symptom checklist)
5. Expected side effects due to use of ß-blocker (physical complaint inventory)


TAIM 1992 (Continued)

Notes

\section{Risk of bias}

\begin{tabular}{|c|c|c|}
\hline Bias & Authors' judgement & Support for judgement \\
\hline $\begin{array}{l}\text { Random sequence genera- } \\
\text { tion (selection bias) }\end{array}$ & Unclear risk & Comment: No details on sequence generation are provided \\
\hline $\begin{array}{l}\text { Allocation concealment } \\
\text { (selection bias) }\end{array}$ & Unclear risk & Comment: Method of concealment is not described \\
\hline $\begin{array}{l}\text { Blinding (performance } \\
\text { bias and detection bias) } \\
\text { All outcomes }\end{array}$ & Low risk & $\begin{array}{l}\text { Comment: The term double-blind in all publications probably refers only to } \\
\text { pharmacological treatment; there is no information on blinding concerning di- } \\
\text { etary interventions }\end{array}$ \\
\hline $\begin{array}{l}\text { Incomplete outcome data } \\
\text { (attrition bias) } \\
\text { All outcomes }\end{array}$ & High risk & $\begin{array}{l}\text { WITHDRAWALS: } 24 \text { in all } 9 \text { groups within first month, } 67 \text { participants without } \\
\text { BP measurement after } 6 \text { months } \\
\text { REASONS/DESCRIPTIONS: - }\end{array}$ \\
\hline $\begin{array}{l}\text { Selective reporting (re- } \\
\text { porting bias) }\end{array}$ & Low risk & Comment: Outcomes are reported as prespecified \\
\hline Other bias & High risk & $\begin{array}{l}\text { Comment: } \\
\text { 1. Step-up medication: } 20 \% \text { (placebo/usual diet) vs } 10 \% \text { (placebo/weight-re- } \\
\text { ducing diets); it is unclear how many participants required an additional open- } \\
\text { label antihypertensive treatment; indication for step-up therapy is presented } \\
\text { inconsistently between study related publications } \\
\text { 2. Unclear whether detection of endpoints was blinded } \\
\text { 3. Number of randomised participants ( } 878 \text { ) is below calculated sample size } \\
\text { (918), although } 1940 \text { participants were eligible }\end{array}$ \\
\hline
\end{tabular}

TAIM 1992 atenolol

\begin{tabular}{ll}
\hline Methods & see TAIM 1992 \\
\hline Participants &
\end{tabular}

Participants

Interventions

Outcomes

Notes

\section{TAIM 1992 chlorthalidone}

\begin{tabular}{ll}
\hline Methods & see TAIM 1992 \\
\hline Participants & \\
\hline Interventions & \\
\hline Outcomes
\end{tabular}

Long-term effects of weight-reducing diets in people with hypertension (Review) 
TAIM 1992 chlorthalidone (Continued)

Notes

TAIM 1992 combined

Methods see TAIM 1992

Participants

Interventions

Outcomes

Notes

TAIM 1992 placebo

Methods See TAIM 1992

Participants

Interventions

\section{Outcomes}

Notes

TONE 1998

DESIGN: parallel, $2 \times 2$ factorial, randomised, blinded endpoint evaluation design
DURATION: 15 to 36 months
NUMBER OF STUDY CENTRES: 4
COUNTRY OF PUBLICATION: USA
SPONSOR: National Heart, Lung and Blood Institute and National Institute on Aging grants

Participants

WHO PARTICIPATED: elderly, obese, and hypertensive patients; participants were assigned to active intervention: sodium reduction $\left(\mathrm{S}^{+}\right)$, or weight loss, or sodium reduction $\left(\mathrm{S}^{+}\right)$and weight loss vs usual care

SETTING: outpatient clinic

MAIN INCLUSION CRITERIA:

age 60 to 80 years; $\mathrm{BMI} \geq 27.8 \mathrm{~kg} / \mathrm{m}^{2}$ (male), $\mathrm{BMI} \geq 27.3 \mathrm{~kg} / \mathrm{m}^{2}$ (women); $\mathrm{SBP}<145 \mathrm{~mm} \mathrm{Hg}$ and $\mathrm{DBP}<$ $85 \mathrm{~mm}$ Hg while taking 1 antihypertensive medication or 2 antihypertensive medications if 1 can be stopped during screening phase (combination of 1 diuretic and 1 non-diuretic drug are considered as 1 drug)

\section{MAIN EXCLUSION CRITERIA:}

heart attack or stroke within preceding 6 months; angina; congestive heart failure; insulin-dependent diabetes mellitus; $\mathrm{BMI}>33 \mathrm{~kg} / \mathrm{m}^{2}$ (men), $\mathrm{BMI}>37 \mathrm{~kg} / \mathrm{m}^{2}$ (women); unexplained or involuntary weight loss of $4.5 \mathrm{~kg}$ or greater during previous year; hypercreatinaemia; hyperkalaemia; hyperglycaemia; anaemia

\section{Dietary-intervention (IG-S-) vs no dietary-intervention group (CG-S-)}


TONE 1998 (Continued)

NUMBER: 147 vs 147 participants were randomised; no information on numbers of participants analysed, however $96 \%$ to $99 \%$ were included for analysis at study end

GENERAL BASELINE CHARACTERISTICS:

MEAN AGE [YEARS]: 66 vs 66

GENDER [\% MALE]: $49 \%$ vs $41 \%$

NATIONALITY: USA

ETHNICITY: white: $73 \%$ vs $68 \%$; African American: $26 \%$ vs $32 \%$

WEIGHT [kg]: 87 vs 86

BODY MASS INDEX $\left[\mathrm{kg} / \mathrm{m}^{2}\right]: 31$ vs 31

SITTING SYSTOLIC BLOOD PRESSURE [mm Hg]: 130 vs 128

SITTING DIASTOLIC BLOOD PRESSURE [mm Hg]: 72 vs 72

COMORBID CONDITIONS: -

ANTIHYPERTENSIVE TREATMENT: $100 \%$ vs $100 \%$

DURATION OF HYPERTENSION [YEARS]: 11 vs 12

\section{Dietary intervention and salt restriction $\left(I G-S^{+}\right)$vs no dietary intervention and salt restriction group (CG-S ${ }^{+}$)}

NUMBER: 147 vs 144 participants were randomised; no information on numbers of participants analysed, however $96 \%$ to $99 \%$ were included for analysis at study end

GENERAL BASELINE CHARACTERISTICS:

MEAN AGE [YEARS]: 66 vs 66

GENDER [\% MALE]: $56 \%$ vs $44 \%$

NATIONALITY: USA

ETHNICITY: white: $76 \%$ vs $70 \%$; African American: $24 \%$ vs $30 \%$

WEIGHT [kg]: 86 vs 88

BODY MASS INDEX [kg/m²]: 31 vs 31

SITTING SYSTOLIC BLOOD PRESSURE [mm Hg]: 129 vs 129

SITTING DIASTOLIC BLOOD PRESSURE [mm Hg]: 72 vs 72

COMORBID CONDITIONS: -

ANTIHYPERTENSIVE TREATMENT: $100 \%$ vs $100 \%$

DURATION OF HYPERTENSION [YEARS]: 12 vs 12

SUBGROUP ANALYSES: age, gender, ethnicity

LENGTH OF FOLLOW-UP: 15 to 36 months

DIETARY INTERVENTION: achieving and maintaining a weight loss of $4.5 \mathrm{~kg}$ or greater; structured programmes with dietary advice provided to participants mainly in small groups to change their eating behaviours and to motivate participants to achieve and maintain their desired reductions; participants were required to increase amount of physical activity, but no detailed information was provided NO DIETARY INTERVENTION: no study-related counselling

ADDITIONAL TREATMENT: Salt restriction $\left(\mathrm{S}^{+}\right)$: achieving and maintaining a 24-hour dietary sodium intake of $80 \mathrm{mmol}$ or less (as measured by 24 -hour urine collection)

Outcomes

PRIMARY OUTCOMES:

1. MORTALITY: reported

2. CARDIOVASCULAR MORBIDITY: reported

3. ADVERSE EVENTS:

Definition: presumed adverse events were assessed using a standardised approach that included questioning of participants, family members, and physicians and a review of physicians' records with blinded evaluation

SECONDARY OUTCOMES:

1. CHANGES IN SYSTOLIC BLOOD PRESSURE [mm Hg]: -

2. CHANGES IN DIASTOLIC BLOOD PRESSURE [mm Hg]: -

3. BODY WEIGHT [kg]: reported for the combined groups only (both intervention (IG-S+ and IG-S-) vs both control (CG-S+ and CG-S-) groups) 
TONE 1998 (Continued)

\section{ADDITIONAL OUTCOMES MEASURED IN THE STUDY:}

1. Primary study endpoint: failure of antihypertensive drug withdrawal due to:

a. occurrence of high blood pressure measured at 1 or more follow-up visits according predefined values;

b. restart of treatment with antihypertensive medication due to other reasons or based on the decision of the treating doctors or study participants;

c. occurrence of clinical cardiovascular disease complications during follow-up.

2. Weight reduction

\section{Notes}

\section{Risk of bias}

\begin{tabular}{|c|c|c|}
\hline Bias & Authors' judgement & Support for judgement \\
\hline $\begin{array}{l}\text { Random sequence genera- } \\
\text { tion (selection bias) }\end{array}$ & Low risk & $\begin{array}{l}\text { Quote: "using a computer program ... stratified by clinic and weight status ... } \\
\text { blocking of variable length" }\end{array}$ \\
\hline $\begin{array}{l}\text { Allocation concealment } \\
\text { (selection bias) }\end{array}$ & Unclear risk & Comment: Method of concealment is not described \\
\hline $\begin{array}{l}\text { Blinding (performance } \\
\text { bias and detection bias) } \\
\text { All outcomes }\end{array}$ & Unclear risk & $\begin{array}{l}\text { Comment: Participants, study personnel were not blinded, but an indepen- } \\
\text { dent committee masked to intervention assignment evaluated the endpoints }\end{array}$ \\
\hline $\begin{array}{l}\text { Incomplete outcome data } \\
\text { (attrition bias) } \\
\text { All outcomes }\end{array}$ & Low risk & $\begin{array}{l}\text { Comment: Numbers of withdrawals and reasons are missing, however } 96 \% \text { to } \\
\text { 99\% of participants were included at follow-up analysis } \\
\text { WITHDRAWALS: - } \\
\text { REASONS/DESCRIPTIONS: - }\end{array}$ \\
\hline $\begin{array}{l}\text { Selective reporting (re- } \\
\text { porting bias) }\end{array}$ & Low risk & Comment: Outcomes are reported as prespecified \\
\hline Other bias & Low risk & - \\
\hline
\end{tabular}

BMI: body mass index

BP: blood pressure

DBP: diastolic blood pressure

HDFP: Hypertension Detection an Follow-up Program

$\mathrm{HDL}$ : high-density lipoprotein

LOCF: last observation carried forward analysis

SBP: systolic blood pressure

Characteristics of excluded studies [ordered by study ID]

Study Reason for exclusion

(no authors listed) 1993

Abou-Raya 2014
The study includes normotensive and hypertensive participants but reports no or insufficient results for the hypertensive subgroup 


\begin{tabular}{|c|c|}
\hline Study & Reason for exclusion \\
\hline Andrews 2011 & $\begin{array}{l}\text { The study includes normotensive and hypertensive participants but reports no or insufficient re- } \\
\text { sults for the hypertensive subgroup }\end{array}$ \\
\hline Angelico 2009 & Full text of this study is not available \\
\hline Appel 2006 & The intervention in this study is not a weight-reducing diet \\
\hline Ard 2005 & The study is not a randomised controlled trial \\
\hline Balas-Nakash 2014 & $\begin{array}{l}\text { The study includes normotensive and hypertensive participants but reports no or insufficient re- } \\
\text { sults for the hypertensive subgroup }\end{array}$ \\
\hline Bao 1999 & Full text of this study is not available \\
\hline Bartels 1974 & The duration of the intervention is less than 24 weeks \\
\hline Bazian 2004 & The study includes a combination of different interventions \\
\hline Bouchonville 2014 & $\begin{array}{l}\text { The study includes normotensive and hypertensive participants but reports no or insufficient re- } \\
\text { sults for the hypertensive subgroup }\end{array}$ \\
\hline Cakir 2006 & The study includes a combination of different interventions \\
\hline Cambien 1986 & Full text of this study is not available \\
\hline Camhi 2010 & $\begin{array}{l}\text { The study includes normotensive and hypertensive participants but reports no or insufficient re- } \\
\text { sults for the hypertensive subgroup }\end{array}$ \\
\hline Chen 2009 & The intervention in this study is not a weight-reducing diet \\
\hline Childress 2008 & Full text of this study is not available \\
\hline Christensen 2013 & $\begin{array}{l}\text { The study includes normotensive and hypertensive participants but reports no or insufficient re- } \\
\text { sults for the hypertensive subgroup }\end{array}$ \\
\hline Coppell 2010 & $\begin{array}{l}\text { The study includes normotensive and hypertensive participants but reports no or insufficient re- } \\
\text { sults for the hypertensive subgroup }\end{array}$ \\
\hline Curzio 1989 & $\begin{array}{l}\text { No electronic records and/or hard copies available, therefore insufficient data for inclusion (per- } \\
\text { sonal communication) }\end{array}$ \\
\hline Cutler 1997 & The study includes a combination of different interventions \\
\hline De Mello 2008 & $\begin{array}{l}\text { The study includes normotensive and hypertensive participants but reports no or insufficient re- } \\
\text { sults for the hypertensive subgroup }\end{array}$ \\
\hline Diaz 2014 & The study does not include participants with essential hypertension \\
\hline Ebell 2013 & The study is not a randomised controlled trial \\
\hline Fagerberg 1989 & The study includes different accompanying therapies \\
\hline Gilliam 2012 & The study is not a randomised controlled trial \\
\hline Gillum 1983 & The duration of the intervention is less than 24 weeks \\
\hline
\end{tabular}




\begin{tabular}{|c|c|}
\hline Study & Reason for exclusion \\
\hline Hall 2003 & $\begin{array}{l}\text { The study includes normotensive and hypertensive participants but reports no or insufficient re- } \\
\text { sults for the hypertensive subgroup }\end{array}$ \\
\hline Haynes 1984 & $\begin{array}{l}\text { The study includes normotensive and hypertensive participants but reports no or insufficient re- } \\
\text { sults for the hypertensive subgroup }\end{array}$ \\
\hline Hayward 2010 & $\begin{array}{l}\text { The study includes normotensive and hypertensive participants but reports no or insufficient re- } \\
\text { sults for the hypertensive subgroup }\end{array}$ \\
\hline He 2000 & The study does not include participants with essential hypertension \\
\hline Heshka 2003 & The study is not a randomised controlled trial \\
\hline Heyden 1974 & The study includes a combination of different interventions \\
\hline Hsieh 2009 & The study is not a randomised controlled trial \\
\hline Hyden 1973 & The study includes a combination of different interventions \\
\hline Jones 1999 & In this study the control group also includes a weight-reducing dietary intervention \\
\hline Karoff 1985 & The duration of the intervention is less than 24 weeks \\
\hline Karvetti 1992 & $\begin{array}{l}\text { The study includes normotensive and hypertensive participants but reports no or insufficient re- } \\
\text { sults for the hypertensive subgroup }\end{array}$ \\
\hline Katzel 1995 & The study does not include participants with essential hypertension \\
\hline Kawamura 1993 & The duration of the intervention is less than 24 weeks \\
\hline Kittiskulnam 2014 & The study does not include participants with essential hypertension \\
\hline Kolehmainen 2008 & $\begin{array}{l}\text { The study includes normotensive and hypertensive participants but reports no or insufficient re- } \\
\text { sults for the hypertensive subgroup }\end{array}$ \\
\hline Korhonen 2003 & Full text of this study is not available \\
\hline Larson-Meyer 2010 & The study does not include participants with essential hypertension \\
\hline Lindgarde 2001 & The intervention in this study is not a weight-reducing diet \\
\hline Mason 2013 & $\begin{array}{l}\text { The study includes normotensive and hypertensive participants but reports no or insufficient re- } \\
\text { sults for the hypertensive subgroup }\end{array}$ \\
\hline Masuo 2012 & The study includes a combination of different interventions \\
\hline McCarron 2000 & The duration of the intervention is less than 24 weeks \\
\hline Metz 2000 & In this study the control group also includes a weight-reducing dietary intervention \\
\hline Noble 1971 & The duration of the intervention is less than 24 weeks \\
\hline Poppitt 2002 & $\begin{array}{l}\text { The study includes normotensive and hypertensive participants but reports no or insufficient re- } \\
\text { sults for the hypertensive subgroup }\end{array}$ \\
\hline
\end{tabular}




\begin{tabular}{|c|c|}
\hline Study & Reason for exclusion \\
\hline Pritchard 2002 & $\begin{array}{l}\text { The study includes normotensive and hypertensive participants but reports no or insufficient re- } \\
\text { sults for the hypertensive subgroup }\end{array}$ \\
\hline Reisin 1978 & The duration of the intervention is less than 24 weeks \\
\hline Rissanen 1985 & The study is not a randomised controlled trial \\
\hline Salas-Salvado 2008 & The intervention in this study is not a weight-reducing diet \\
\hline Salinardi 2012 & $\begin{array}{l}\text { The study includes normotensive and hypertensive participants but reports no or insufficient re- } \\
\text { sults for the hypertensive subgroup }\end{array}$ \\
\hline Samaha 2003 & $\begin{array}{l}\text { The study includes normotensive and hypertensive participants but reports no or insufficient re- } \\
\text { sults for the hypertensive subgroup }\end{array}$ \\
\hline Schwab 2008 & $\begin{array}{l}\text { The study includes normotensive and hypertensive participants but reports no or insufficient re- } \\
\text { sults for the hypertensive subgroup }\end{array}$ \\
\hline Stamler 1985 & The study includes a combination of different interventions \\
\hline Tate 2011 & $\begin{array}{l}\text { The study includes normotensive and hypertensive participants but reports no or insufficient re- } \\
\text { sults for the hypertensive subgroup }\end{array}$ \\
\hline Trepanowski 2014 & $\begin{array}{l}\text { The study includes normotensive and hypertensive participants but reports no or insufficient re- } \\
\text { sults for the hypertensive subgroup }\end{array}$ \\
\hline Tunyan 2007 & The study includes a combination of different interventions \\
\hline Tuomilehto 2009 & The study does not include participants with essential hypertension \\
\hline Vissers 2010 & The study does not include participants with essential hypertension \\
\hline WHO Europ.Coll.Grp. 1974 & The study is not a randomised controlled trial \\
\hline Yamada 2013 & $\begin{array}{l}\text { The study includes normotensive and hypertensive participants but reports no or insufficient re- } \\
\text { sults for the hypertensive subgroup }\end{array}$ \\
\hline
\end{tabular}

\section{DATA AND ANALYSES}

\section{Comparison 1. Weight-reducing diet versus no weight-reducing diet}

\begin{tabular}{lllll}
\hline Outcome or subgroup title & $\begin{array}{l}\text { No. of } \\
\text { studies }\end{array}$ & $\begin{array}{l}\text { No. of } \\
\text { partici- } \\
\text { pants }\end{array}$ & Statistical method & Effect size \\
\hline $\begin{array}{l}1 \text { Change in systolic blood pressure from } \\
\text { baseline to endpoint }\end{array}$ & 4 & 731 & $\begin{array}{l}\text { Mean Difference (IV, Random, 95\% } \\
\text { CI) }\end{array}$ & $-4.49[-7.20,-1.78]$ \\
\hline $\begin{array}{l}2 \text { Change in diastolic blood pressure from } \\
\text { baseline to endpoint }\end{array}$ & 6 & 731 & $\begin{array}{l}\text { Mean Difference (IV, Random, 95\% } \\
\text { CI) }\end{array}$ & $-3.19[-4.83,-1.54]$ \\
\hline
\end{tabular}




\begin{tabular}{lllll}
\hline Outcome or subgroup title & $\begin{array}{l}\text { No. of } \\
\text { studies }\end{array}$ & $\begin{array}{l}\text { No. of } \\
\text { partici- } \\
\text { pants }\end{array}$ & Statistical method & Effect size \\
\hline $\begin{array}{l}\text { 3 Change in body weight from baseline to } \\
\text { endpoint }\end{array}$ & 7 & 880 & $\begin{array}{l}\text { Mean Difference (IV, Random, 95\% } \\
\text { Cl) }\end{array}$ & $-3.98[-4.79,-3.17]$ \\
\hline
\end{tabular}

Analysis 1.1. Comparison 1 Weight-reducing diet versus no weight-reducing diet, Outcome 1 Change in systolic blood pressure from baseline to endpoint.

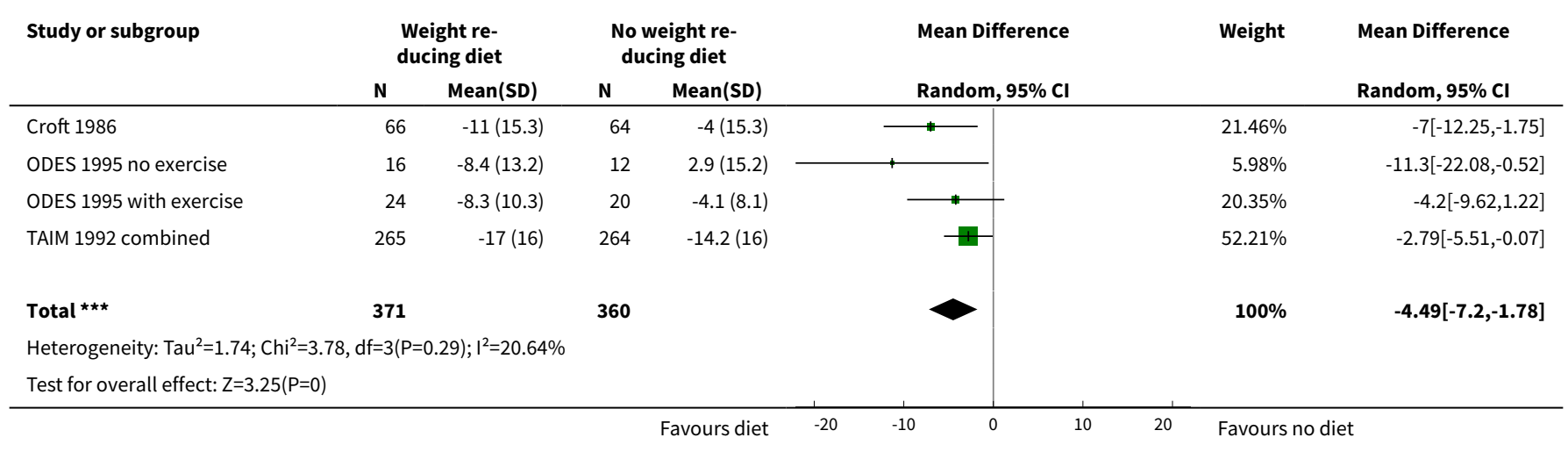

Analysis 1.2. Comparison 1 Weight-reducing diet versus no weight-reducing diet, Outcome 2 Change in diastolic blood pressure from baseline to endpoint.

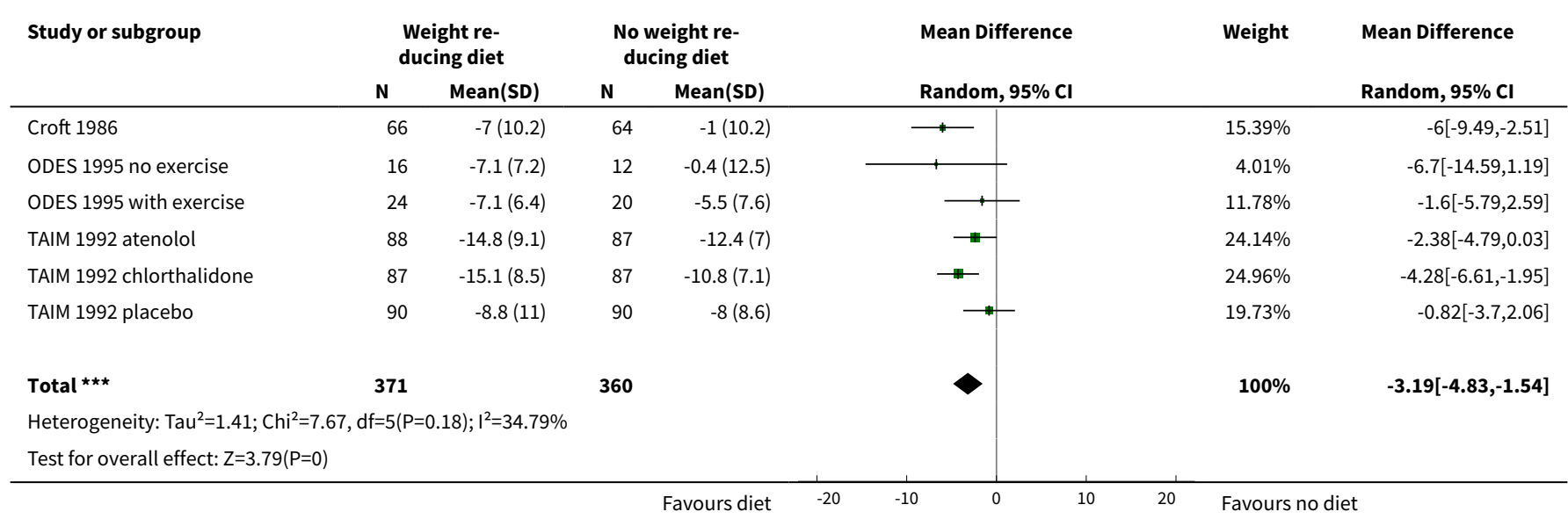


Analysis 1.3. Comparison 1 Weight-reducing diet versus no weightreducing diet, Outcome 3 Change in body weight from baseline to endpoint.

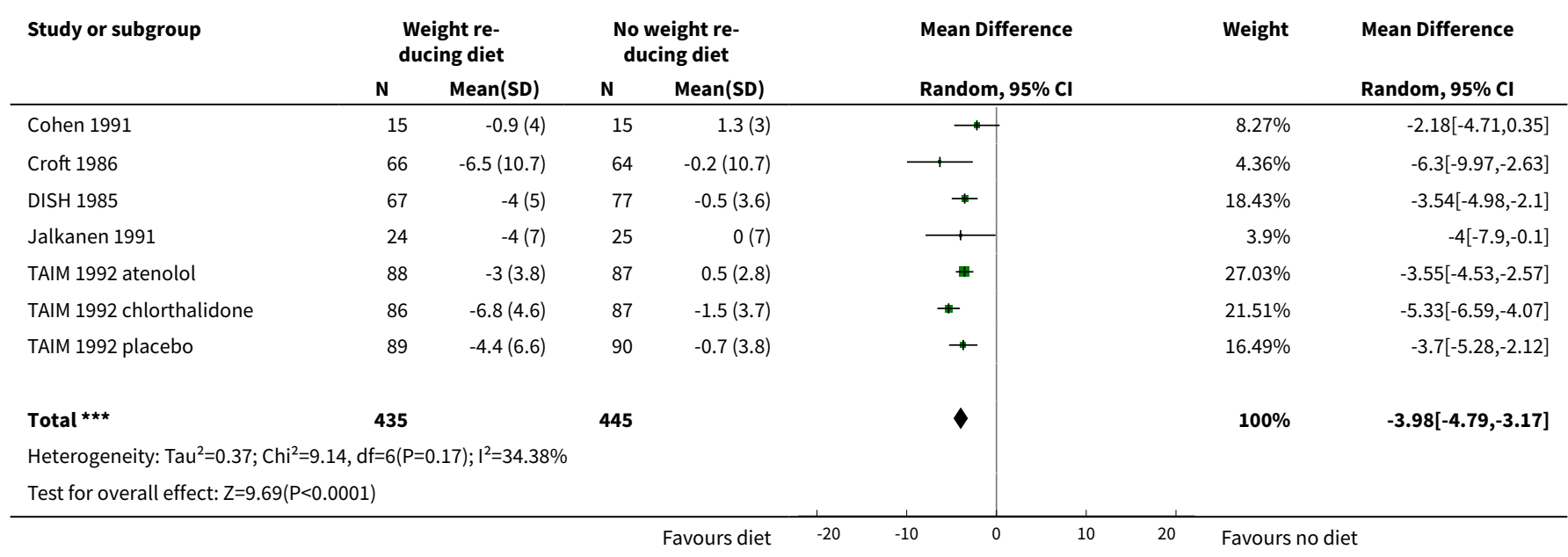

\section{ADDITIONAL TABLES}

Table 1. Body weight

\begin{tabular}{|c|c|c|c|c|c|}
\hline \multirow[t]{2}{*}{ Study } & \multicolumn{5}{|c|}{ Body weight $[\mathrm{kg}]^{a}$} \\
\hline & Baseline & 6 months & 12 months & $>12$ months & Change (baseline to endpoint) \\
\hline Cohen 1991 & $92^{b}$ & n. r. & n. r. & $-c$ & $-0.9(4.0)$ vs \\
\hline IG & $92^{b}$ & n. r. & n. r. & $-c$ & $+1.3(3.0) ; P<0.1$ \\
\hline \multicolumn{6}{|l|}{ CG } \\
\hline \multicolumn{6}{|l|}{ Croft 1986} \\
\hline IG & $87(4)$ & $80(4)$ & $-c$ & $-c$ & $-6.5^{b}$ vs \\
\hline CG & $82(3)$ & $82(3)$ & $-c$ & $-c$ & $-0.2^{b} ; \mathrm{P}<0.001$ \\
\hline \multicolumn{6}{|c|}{ Jalkanen 1991} \\
\hline IG & $86(14)$ & n. $r$. & $82(13)$ & $-c$ & $-4.0^{d}$ vs \\
\hline CG & $80(11)$ & n. r. & $80(11)$ & $-c$ & $0.0 d ; P<0.05$ \\
\hline
\end{tabular}

DISH 1984 to 1985

$\begin{array}{llllll}\text { IG } & 86(17) & \text { n. r. } & \text { n. r. } & -c & -4.0(5.0) \text { vs } \\ \text { CG } & 90(18) & \text { n. r. } & \text { n. r. } & -c & -0.5(3.6) ; P<0.05^{e}\end{array}$

ODES 1993 to $2001^{f}$

n. r.

n. r.

n. r.

n. r.

n. r.

Ruvolo 1994
IG
$98(8)$
$84(9)$
$-c$
$-c$
$-14 b, g$ vs 
Table 1. Body weight

CG $97(8)$

\section{TAIM 1989 to 1994}

\begin{tabular}{|c|c|c|c|c|c|}
\hline IG-P & $90^{b}$ & n. r. & n. r. & n. r. ${ }^{h}$ & $-4.4(0.7)^{j}$ vs \\
\hline CG-P & $86^{b}$ & n. r. & n. r. & n. r. ${ }^{h}$ & $-0.7(0.4) j ;$ n. r. \\
\hline IG-A & $86 b$ & n. r. & n. r. & n. r. ${ }^{h}$ & $-3.0(0.4) j \mathrm{vs}$ \\
\hline CG-A & $89 b$ & n. r. & n. r. & n. r. $h$ & $+0.5(0.3) j ;$ n. r. \\
\hline IG-C & $87^{b}$ & n. r. & n. r. & n. r. ${ }^{h}$ & $-6.9(0.5)^{j} \mathrm{vs}$ \\
\hline CG-C & $89 b$ & n. r. & n. r. & n. r. ${ }^{h}$ & $-1.5(0.4) j ;$ n. r. \\
\hline
\end{tabular}

TONE 1995 to 2002

$\begin{array}{llllll}\text { IG-S- } & 87(10) & \text { n.r. } & \text { n. r. } & \text { n. r. } & \text { n. r.k } \\ \text { CG-S- } & 86(10) & \text { n.r. } & \text { n. r. } & \text { n.r. } & \text { n. r.k } \\ \text { IG-S+ } & 86(10) & \text { n.r. } & \text { n. r. } & \text { n. r. } & \text { n. r.k } \\ \text { CG-S+ } & 88(11) & \text { n.r. } & \text { n.r. } & \text { n. r. } & \text { n. r.k }\end{array}$

a Mean (standard deviation), unless otherwise indicated.

$b$ Data on variance missing.

cobservation period $\leq 12$ months.

$d$ Numbers calculated from the tables of publications. A mean weight reduction of $5 \mathrm{~kg}$ is stated in the text section.

eInformation on body weight was available for $77 \%$ of participants in the intervention group and $87 \%$ of participants in the control group.

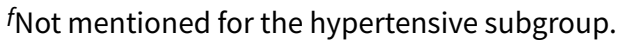

gCalculated from table 1 in Ruvolo 1994.

hOnly change in body weight reported for 24 months; since no other outcomes were reported for this time, and change in body weight is not a primary endpoint of this report, data were not extracted.

jStandard error.

kWeight reduction of $3.9 \mathrm{vs} 0.9 \mathrm{~kg}(\mathrm{P}<0.001)$ in overweight participants of both intervention groups together (with and without salt restriction) vs control group.

[CG]: control group. [CG-A]: control group + atenolol. [CG-C]: control group + chlortalidone. [CG-P]: control group + placebo. [CG-S + ]: control group + salt restriction. [CG-S-]: control group without salt restriction. [IG]: intervention group. [IG-A]: intervention group + atenolol. [IG-C]: intervention group + chlortalidone. [IG-P]: intervention group + placebo. [IG-S+]: intervention group + salt restriction. [IG-S-]: intervention group without salt restriction. [n. r.]: not reported.

Table 2. Systolic blood pressure

\begin{tabular}{|c|c|c|c|c|c|}
\hline \multirow[t]{2}{*}{ Study } & \multicolumn{5}{|c|}{ Systolic blood pressure [mm Hg] ${ }^{a}$} \\
\hline & Baseline & 6 months & 12 months & & Change (baseline to endpoint) \\
\hline Cohen 1991 & n. r. $b$ & n. r. & n. r. & $-c$ & n. r. $b$ \\
\hline IG & n. $r^{b}$ & n. r. & n. $r$. & $-c$ & n. r. $b$ \\
\hline CG & & & & & \\
\hline
\end{tabular}


Table 2. Systolic blood pressure (Continued)

\section{Croft 1986}

$\begin{array}{llllll}\text { IG } & 161(4) & 150(4) & -c & -c & -11.0^{d} \text { Vs } \\ \text { CG } & 161(4) & 157(4) & -c & -c & -4.0 d ; P<0.01\end{array}$

Jalkanen 1991

\begin{tabular}{llllll} 
IG & $152(17)$ & n. r. & $144(20)$ & $-c$ & $-8.0^{d}$ vs \\
CG & $155(14)$ & n. r. & $140(16)$ & $-c$ & $-15.0 d$; n. r. \\
\hline DISH 1984 to 1985 & $-e$ & $-e$ & $-e$ & $-e$ & $-e$ \\
\hline
\end{tabular}

ODES 1993 to 2001

$\begin{array}{llllll}\text { IG } & 145(5)^{f} & \text { n. r. } & \text { n. r. } & -c & -8.4(3.3)^{f} \text { Vs } \\ \text { CG } & 138(3)^{f} & \text { n. r. } & \text { n. r. } & -c & 2.9(4.4)^{f} ; \mathrm{P}<0.05\end{array}$

$\begin{array}{llllll}\text { IG-KA+ } & 143(2)^{f} & \text { n. r. } & \text { n. r. } & -c & -8.3(2.1)^{f} \text { Vs } \\ \text { CG-KA+ } & 140(2)^{f} & \text { n. r. } & \text { n. r. } & -c & -4.1(1.8)^{f} ; \text { n. r. }\end{array}$

\section{Ruvolo 1994}

$\begin{array}{llllll}\text { IG } & 178(8) & 145(6) & -c & -c & -33^{d, g} \text { vs } \\ \text { CG } & 176(8) & 144(6) & -c & -c & -32 \text { d,g; n. r. }\end{array}$

\section{TAIM 1989 to 1994}

\begin{tabular}{|c|c|c|c|c|c|}
\hline IG-P & $143^{d}$ & n. r. ${ }^{h}$ & n. r. & n. r. & $-11.5^{d}$ vs \\
\hline CG-P & $145^{d}$ & n. r. $h$ & n. r. & n. r. & $-10.3^{d} ;$ n. r. \\
\hline IG-A & $143^{d}$ & n. r. $h$ & n. r. & n. r. & $-18.1^{d}$ vs \\
\hline CG-A & $143^{d}$ & n. r. ${ }^{h}$ & n. r. & n. r. & $-15.1^{d} ;$ n. r. \\
\hline IG-C & $141^{d}$ & n. r. ${ }^{h}$ & n. r. & n. r. & $-21.7^{d}$ vs \\
\hline CG-C & $142^{d}$ & n. r. ${ }^{h}$ & n. r. & n. r. & $-17.4^{d} ;$ n. r. \\
\hline TONE 1995 to 2002 & -e & $-e$ & -e & $-e$ & $-e$ \\
\hline
\end{tabular}

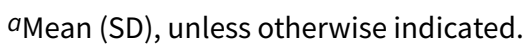

bOnly the mean arterial blood pressure is reported (at baseline: IG and CG $106 \mathrm{~mm} \mathrm{Hg}$ each; change from baseline to endpoint: IG +3.0 (SD 14.2) $\mathrm{mm} \mathrm{Hg}$ and CG -0.7 (SD 11.3) $\mathrm{mm} \mathrm{Hg}$ ).

cobservation period $\leq 12$ months.

$d$ Data on variance missing.

epurpose of the study was not the change in blood pressure, but the number of participants without any antihypertensive drug requirements at the end of the study after successful withdrawal of antihypertensives.

fStandard error.

gCalculated from table 1 in Ruvolo 1994.

honly changes from baseline are reported, no absolute values. 
[CG]: control group. [CG-A]: control group + atenolol. [CG-C]: control group + chlortalidone. [CG-P]: control group + placebo. [CG-PA+]: control group + physical activity. [IG]: intervention group. [IG-A]: intervention group + atenolol. [IG-C]: intervention group + chlortalidone.

[IG-P]: intervention group + placebo. [IG-PA+]: intervention group + physical activity. [n. r.]: not reported. [SD]: standard deviation.

Table 3. Diastolic blood pressure

\begin{tabular}{|c|c|c|c|c|c|}
\hline \multirow{3}{*}{$\begin{array}{l}\text { Study } \\
\text { Cohen } 1991\end{array}$} & \multicolumn{5}{|c|}{ Diastolic blood pressure [mm Hg] ${ }^{a}$} \\
\hline & \multirow{2}{*}{$\begin{array}{l}\text { Baseline } \\
\text { n. r. } b\end{array}$} & \multirow{2}{*}{$\begin{array}{l}6 \text { months } \\
\text { n. r. }\end{array}$} & \multirow{2}{*}{$\begin{array}{l}12 \text { months } \\
\text { n. r. }\end{array}$} & \multicolumn{2}{|c|}{$>12$ months Change (baseline to endpoint) } \\
\hline & & & & $-c$ & n. r. $b$ \\
\hline IG & n. r. $b$ & n. r. & n. r. & $-c$ & n. r. $b$ \\
\hline \multicolumn{6}{|l|}{ CG } \\
\hline Croft 1986 & & & $-c$ & $-c$ & \\
\hline IG & $98(2)$ & $91(2)$ & $-c$ & $-c$ & $-7.0^{d} \mathrm{vs}$ \\
\hline CG & $96(2)$ & $95(2)$ & & & $-1.0 d ; P<0.001$ \\
\hline Jalkanen 1991 & & & & $-c$ & \\
\hline IG & $101(8)$ & n. r. & $90(10)$ & $-c$ & $-11.0^{d} \mathrm{vs}$ \\
\hline CG & $102(7)$ & n. r. & $91(7)$ & & $-11.0^{d} ; \mathrm{n} . \mathrm{r}$. \\
\hline DISH 1984 to 1985 & $-e$ & $-e$ & $-e$ & $-e$ & $-e$ \\
\hline \multicolumn{6}{|l|}{ ODES 1993 to 2001} \\
\hline IG & $97(1)^{f}$ & n. r. & n. r. & $-c$ & $-7.1(1.8)^{f}$ Vs \\
\hline CG & $96(1)^{f}$ & n. r. & n. r. & $-c$ & $-0.4(3.6)^{f} ; \mathrm{ns}$ \\
\hline IG- KA+ & $97(1)^{f}$ & n. r. & n. r. & $-c$ & $-7.1(1.3)^{f} \mathrm{vs}$ \\
\hline CG-KA+ & $96(1)^{f}$ & n. r. & n. r. & $-c$ & $-5.5(1.7)^{f} ;$ n. r. \\
\hline \multicolumn{6}{|l|}{ Ruvolo 1994} \\
\hline IG & $107(5)$ & $84(4)$ & $-c$ & $-c$ & $-23 \mathrm{~d}, \mathrm{~g}$ vs \\
\hline CG & $106(5)$ & $85(5)$ & $-c$ & $-c$ & $-21^{d, g} ;$ n. r. \\
\hline \multicolumn{6}{|l|}{ TAIM 1989 to 1994} \\
\hline IG & n. r. & n. r. $h$ & n. r. & n. r. & $-12.8(10.0)$ vs \\
\hline CG & n. r. & n. r. ${ }^{h}$ & n. r. & n. r. & $-10.4(7.8) ; P=0.001^{i}$ \\
\hline TONE 1995 to 2002 & $-e$ & $-e$ & $-e$ & $-e$ & $-e$ \\
\hline
\end{tabular}

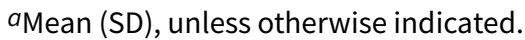

bonly the mean arterial blood pressure is reported (at baseline: IG and CG $106 \mathrm{~mm} \mathrm{Hg}$ each; change from baseline to endpoint: IG +3.0 (SD 14.2) $\mathrm{mm} \mathrm{Hg}$ and CG -0.7 (SD 11.3) $\mathrm{mm} \mathrm{Hg}$ ).

cObservation period $\leq 12$ months.

$d$ Data on variance missing. 
ePurpose of the study was not the change in blood pressure, but the number of participants without any antihypertensive drug requirements at the end of the study after successful withdrawal of antihypertensives.

fStandard error.

gCalculated from table 1 in Ruvolo 1994.

hOnly changes from baseline are reported, no absolute values.

iP $=0.002$ reported in another publication.

[CG]: control group. [CG-A]: control group + atenolol. [CG-C]: control group + chlortalidone. [CG-P]: control group + placebo. [CG-PA+]: control group + physical activity. [IG]: intervention group. [IG-A]: intervention group + atenolol. [IG-C]: intervention group + chlortalidone. [IG-P]: intervention group + placebo. [IG-PA+]: intervention group + physical activity. [n. r.]: not reported. [ns]: not significant. [SD]: standard deviation.

\section{AP PEN DICES}

\section{Appendix 1. Search strategies}

Database: Ovid MEDLINE(R) 1946 to Present with Daily Update Search Date: 2 February 2015

1 (adipos\$ or antiadipos $\$$ or antiobes $\$$ or bodyweight or obes\$ or overweight or weight\$).mp. (1095649)

2 (aliment $\$$ or diet\$ or eat $\$$ or fare or feed\$ or food\$ or nourishment $\$$ or nutrit $\$$ ).mp. (1184712)

3 hypertension/ (193098)

4 (antihypertens\$ or hypertens\$).ti,ab,ot. (316377)

5 exp blood pressure/ (247959)

6 (blood pressure\$ or bloodpressure\$).ti,ab,ot. (216221)

7 or/3-6 (592086)

8 randomized controlled trial.pt. (382126)

9 pragmatic clinical trial.pt. (94)

10 controlled clinical trial.pt. (88433)

11 randomized.ab. (280881)

12 placebo.ab. (147976)

13 clinical trials as topic/ (170476)

14 randomly.ab. (199395)

15 trial.ti. (120826)

16 or/8-15 (875513)

17 animals/ not (humans/ and animals/) (3883708)

1816 not 17 (803039)

191 and 2 and 7 and 18 (2713)

20 remove duplicates from 19 (2688)

Database: Cochrane Central Register of Controlled Trials (CENTRAL) 2015, Issue 1 via the Cochrane Register of Studies Online 
Search Date: 4 February 2015

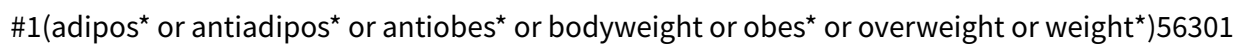

\#2(aliment ${ }^{\star}$ or diet $^{\star}$ or eat* or food $^{\star}$ or nourishment ${ }^{\star}$ or nutrit* $) 65236$

\#3antihypertens* or hypertens*35510

\#4(elevat* OR lower* OR high OR raised) AND (blood pressure OR bloodpressure or bp) 20239

\#5\#3 OR \#446939

\#6\#1 AND \#2 AND \#52015

Database: Embase <1974 to 2015 February 03>

Search Date: 4 February 2015

1 (adipos\$ or antiadipos\$ or antiobes\$ or bodyweight or obes\$ or overweight or weight\$).mp. (1468599)

2 (aliment\$ or diet\$ or eat\$ or fare or feed\$ or food\$ or nourishment\$ or nutrit\$).mp. (1685480)

3 exp hypertension/ (514055)

4 (antihypertens\$ or hypertens\$).ti,ab,ot. (466888)

5 exp blood pressure/ (415262)

6 (blood pressure\$ or bloodpressure\$).ti,ab,ot. (302279)

7 or/3-6 (973509)

8 randomized controlled trial/ (360388)

9 crossover procedure/ (41301)

10 double-blind procedure/ (119849)

11 (randomi?ed or randomly).tw. (755175)

12 (crossover\$ or cross-over\$).tw. (73881)

13 placebo.ab. (204813)

14 (doubl\$ adj blind\$).tw. (153334)

15 assign\$.ab. (247698)

16 allocat\$.ab. (87318)

17 or/8-16 (1153398)

18 (exp animal/ or animal.hw. or nonhuman/) not (exp human/ or human cell/ or (human or humans).ti.) (5532735)

1917 not $18(1002841)$

201 and 2 and 7 and 19 (5427)

21 remove duplicates from 20 (5364) 
Database: Hypertension Group Specialised Register

Search Date: 4 February 2015

\#1 (adipos* or antiadipos ${ }^{\star}$ or antiobes* or bodyweight or obes* or overweight or weight $\left.{ }^{\star}\right) 8310$

\#2 (aliment ${ }^{\star}$ or diet ${ }^{\star}$ or eat ${ }^{\star}$ or food ${ }^{\star}$ or nourishment ${ }^{\star}$ or nutrit*) 7456

\#3 antihypertens* or hypertens ${ }^{\star} 32571$

\#4 (elevat ${ }^{\star}$ OR lower ${ }^{\star}$ OR high OR raised) AND (blood pressure OR bloodpressure or bp) 16739

\#5 \#3 OR \#4 38956

\#6 (RCT OR Review OR Meta-Analysis):DE 22333

\#7 \#1 AND \#2 AND \#5 AND \#6 1361

Database: ClinicalTrials.gov (via Cochrane Register of Studies)

Search Date: 4 February 2015

Search terms: randomized AND (bodyweight OR overweight OR weight)

Study type: Interventional Studies

Conditions: hypertension

Intervention: dietary (113)

\section{Appendix 2. Search strategies used in original review}

Database: Ovid MEDLINE(R) 1966 to Present with Daily Update

Search Strategy:

1 exp hypertension/ or exp blood pressure/

2 (hypertens\$ or antihypertens\$ or anti hypertens\$).ti,ab,ot.

3 ((systolic or diastolic or arterial) adj pressur\$).ti,ab,ot.

4 (blood pressur\$ or bloodpressur\$).ti,ab,ot.

5 or/ $1-4$

6 (weigh $\$$ or overweight or bodyweight or obes\$ or adipos $\$$ or antiobes $\$$ or antiadipos\$).ti,ab,ot,hw,kf.

7 (diet\$ or nutriti\$ or food\$ or feed\$ or fare or eat\$ or nourishment\$ or aliment\$).ti,ab,ot,hw,kf.

8 exp nutrition therapy/

9 or $/ 7-8$

10 and $/ 5-6,9$

11 controlled clinical trial.pt.

12 exp Controlled Clinical Trials as Topic/

13 randomized controlled trial.pt.

14 Randomized Controlled Trials as Topic/

15 random allocation/

16 cross-over studies/

17 Double-Blind Method/

18 Single-Blind Method/

19 or/11-18

20 ((singl\$ or doubl\$ or trebl\$ or tripl\$) adj6 (blind\$ or mask\$)).ti,ab,ot.

21 ((random\$ or cross-over or crossover) adj25 (trial\$ or study or studies or intervention\$ or investigat\$ or experiment\$ or design\$ or method\$ or group\$ or evaluation\$ or evidenc\$ or data or test $\$$ or condition\$)).ti,ab,ot.

22 (random $\$$ adj25 (cross over or crossover)).ti,ab,ot.

23 (RCT or placebo\$).ti,ab,ot.

24 or/20-23

2519 or 24

26 Animals/

27 Humans/

2826 not 27

2925 not 28

3010 and 29 
Database: EMBASE (Ovid) <1988 to 2010>

Search Strategy:

1 exp hypertension/ or exp blood pressure/

2 (hypertens\$ or antihypertens\$ or anti hypertens\$).ti,ab,ot.

3 ((systolic or diastolic or arterial) adj pressur\$).ti,ab,ot.

4 (blood pressur\$ or bloodpressur\$).ti,ab,ot.

5 or/1-4

6 (weigh\$ or overweight or bodyweight or obes\$ or adipos\$ or antiobes\$ or antiadipos\$).ti,ab,ot,hw,kf.

7 (diet $\$$ or nutriti\$ or food $\$$ or feed $\$$ or fare or eat $\$$ or nourishment $\$$ or aliment $\$$ ).ti,ab,ot,hw,kf.

8 exp nutrition/

9 or $/ 7-8$

10 and/5-6,9

11 controlled clinical trial/

12 randomized controlled trial/

13 randomization/

14 crossover procedure/

15 double blind procedure/

16 single blind procedure/

17 or/11-16

18 ((singl\$ or doubl\$ or trebl\$ or tripl\$) adj6 (blind\$ or mask\$)).ti,ab,ot.

19 ((random\$ or cross-over or crossover) adj25 (trial\$ or study or studies or intervention\$ or investigat\$ or experiment\$ or design\$ or method\$ or group\$ or evaluation $\$$ or evidenc\$ or data or test\$ or condition\$)).ti,ab,ot.

20 (random\$ adj25 (cross over or crossover)).ti,ab,ot.

21 (RCT or placebo\$).ti,ab,ot.

22 or/18-21

2317 or 22

24 animal/ not human/

2523 not 24

2610 and 25

Database: EBM Reviews - Cochrane Central Register of Controlled Trials (Ovid) <4th Quarter 2010>

Search Strategy:

1 exp hypertension/ or exp blood pressure/

2 (hypertens\$ or antihypertens\$ or anti hypertens\$).ti,ab,ot.

3 ((systolic or diastolic or arterial) adj pressur\$).ti,ab,ot.

4 (blood pressur\$ or bloodpressur\$).ti,ab,ot.

5 or/1-4

6 (weigh\$ or overweight or bodyweight or obes\$ or adipos\$ or antiobes\$ or antiadipos\$).ti,ab,ot,hw,kf.

7 (diet\$ or nutriti\$ or food\$ or feed\$ or fare or eat\$ or nourishment\$ or aliment\$).ti,ab,ot,hw,kf.

8 exp nutrition therapy/

9 or/7-8

10 and/5-6,9

\section{WHAT'S NEW}

\begin{tabular}{lll}
\hline Date & Event & Description \\
\hline 2 February 2016 & New search has been performed & $\begin{array}{l}\text { We updated the search for new studies in February 2015. We } \\
\text { identified no new studies that met the inclusion criteria of this } \\
\text { review. We have added a 'Summary of findings' table. }\end{array}$ \\
\hline
\end{tabular}




\begin{tabular}{lll}
\hline Date & Event & Description \\
\hline 2 February 2016 & $\begin{array}{l}\text { New citation required but conclusions } \\
\text { have not changed }\end{array}$ & $\begin{array}{l}\text { Update published with changed authors, updated search, con- } \\
\text { clusions not changed. }\end{array}$ \\
\hline
\end{tabular}

\section{CONTRIBUTIONS OF AUTHORS}

Thomas Semlitsch: selection of studies, quality assessment of trials, data extraction, development of review update, corresponding author. Klaus Jeitler: protocol development, searching for trials, quality assessment of trials, data extraction.

Andrea Berghold: statistical analysis, development of final review.

Karl Horvath: protocol development, quality assessment of trials, data extraction, development of final review.

Nicole Posch: selection of studies, development of review update.

Stephanie Poggenburg: selection of studies, development of review update.

Andrea Siebenhofer: protocol development, quality assessment of trials, selection of studies, data extraction, development of final review and review update.

\section{DECLARATIONS OF INTEREST}

Andrea Siebenhofer, Klaus Jeitler, and Karl Horvath were involved in the preparation of a report on the evaluation of the benefits and harms of non-drug treatment strategies in patients with essential hypertension: weight reduction for IQWiG, the German Institute for Quality and Efficiency in Health Care (http://iqwig.de/).

Andrea Berghold, Thomas Semlitsch, Stephanie Poggenburg, and Nicole Posch have no potential conflicts of interest to declare.

\section{SOURCES OF SUPPORT}

\section{Internal sources}

- Medical University of Graz, Austria.

- Institute of General Practice, Goethe University Frankfurt, Germany.

\section{External sources}

- No sources of support supplied

\section{DIFFERENCES BETWEEN PROTOCOLANDREVIEW}

Three new authors (Thomas Semlitsch, Christoph Pachler, and Reinhard Strametz) joined the team of review authors for the 2011 version of this review and provided substantive intellectual contributions that justify their inclusion as authors.

Nicole Pignitter changed her name to Nicole Posch due to marriage, and her new name is used in the 2015 update of this review.

Four authors (Andreas Waltering, Lars Hemkens, Christoph Pachler, and Reinhard Strametz) did not contribute to the 2015 update of this review and were removed from the list of authors.

Stephanie Poggenburg joined the team of authors for the 2015 update of this review and provided substantive intellectual contributions that justify her inclusion as author.

We limited our full review to an EMBASE search from 1988 onwards, because we expected no further relevant results from the period of 1980 to 1988.

\section{INDEX TERMS}

\section{Medical Subject Headings (MeSH)}

Blood Pressure; Cardiovascular Diseases [prevention \& control]; Diet, Reducing [ ${ }^{\star}$ adverse effects]; Hypertension [ ${ }^{\star}$ diet therapy] [mortality]; Randomized Controlled Trials as Topic; Weight Loss 


\section{MeSH check words}

Aged; Humans; Middle Aged 